Nevada

Environmental

Restoration

Project

\title{
Corrective Action Investigation Plan for Corrective Action Unit 234: Mud Pits, Cellars, and Mud Spills Nevada Test Site, Nevada
}

Controlled Copy No::

Revision No.: 0

August 2007

Approved for public release; further dissemination unlimited.

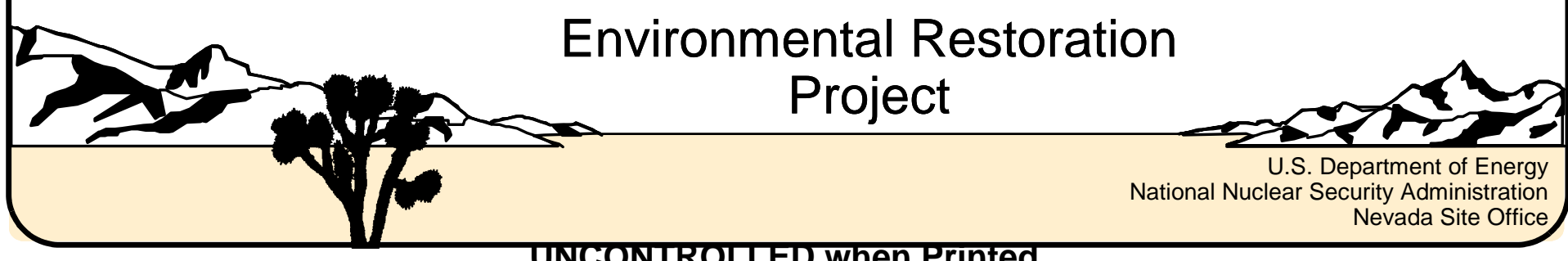


Available for sale to the public from:

U.S. Department of Commerce

National Technical Information Service

5285 Port Royal Road

Springfield, VA 22161

Phone: 800.553 .6847

Fax: 703.605.6900

Email: orders@ntis.gov

Online ordering: http://www.ntis.gov/ordering.htm

Available electronically at http://www.osti.gov/bridge

Available for a processing fee to U.S. Department of Energy and its contractors, in paper, from:

U.S. Department of Energy

Office of Scientific and Technical Information

P.O. Box 62

Oak Ridge, TN 37831-0062

Phone: 865.576.8401

Fax: 865.576.5728

Email: reports@adonis.osti.gov

Reference herein to any specific commercial product, process, or service by trade name, trademark, manufacturer, or otherwise, does not necessarily constitute or imply its endorsement, recommendation, or favoring by the United States Government or any agency thereof or its contractors or subcontractors. 


\title{
CORRECTIVE ACTION INVESTIGATION PLAN FOR CORRECTIVE ACTION UNIT 234: MUD PITS, CELLARS, AND MUD SPILLS NEVADA TEST SITE, NEVADA
}

\author{
U.S. Department of Energy \\ National Nuclear Security Administration \\ Nevada Site Office \\ Las Vegas, Nevada
}

Controlled Copy No.:

Revision No.: 0

August 2007

Approved for public release; further dissemination unlimited. 


\section{CORRECTIVE ACTION INVESTIGATION PLAN FOR}

CORRECTIVE ACTION UNIT 234:

MUD PITS, CELLARS, AND MUD SPILLS

NEVADA TEST SITE, NEVADA

Approved by: /s/ Sabine Curtis

Date: $08 / 01 / 2007$

Sabine T. Curtis

Acting Federal Sub-Project Director

Industrial Sites Sub-Project

Approved by: /s/ Wilhelm R. Wilborn for

Date: $08 / 01 / 2007$

Kevin J. Cabble

Acting Federal Project Director

Environmental Restoration Project 


\section{Table of Contents}

List of Figures vii

List of Tables ...X

List of Acronyms and Abbreviations ................................................................................. Executive Summary ES-1

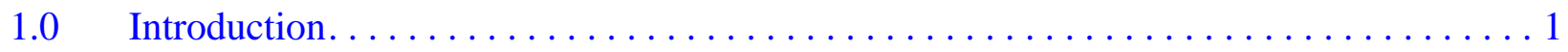

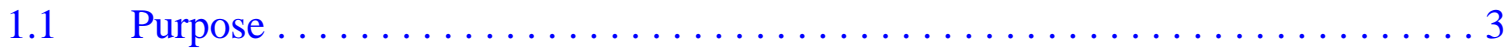

1.1.1 Corrective Action Unit 234 History and Description. . . . . . . . . . . . 3

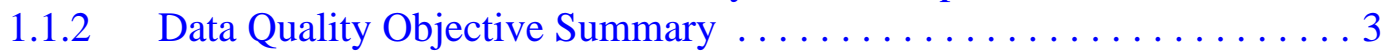

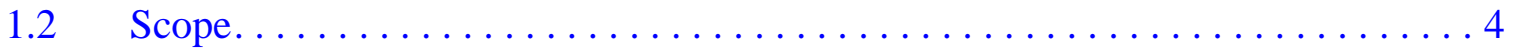

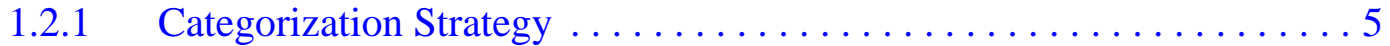

1.3 Corrective Action Investigation Plan Contents $\ldots \ldots \ldots \ldots \ldots \ldots \ldots$

$2.0 \quad$ Facility Description. . . . . . . . . . . . . . . . . 6

2.1 Physical Setting. . . . . . . . . . . . . . . . . . . . . . . 6

$2.1 .1 \quad$ Yucca Flat. . . . . . . . . . . . . . . . . . . . . . . 6

2.1.2 Rainier Mesa. ............................ 7

2.2 Operational History. . . . . . . . . . . . . . . . . . . . . 7

2.2.1 Corrective Action Site 02-09-48, Area 2 Mud Plant \#1 . . . . . . . . . . . 7

2.2.2 Corrective Action Site 02-09-49, Area 2 Mud Plant \#2. . . . . . . . . . . . 8

2.2.3 Corrective Action Site 02-99-05, Mud Spill . . . . . . . . . . . . . . . . . 8

2.2.4 Corrective Action Site 03-09-02, Mud Dump Trenches . . . . . . . . . . 10

2.2.5 Corrective Action Site 04-44-02, Mud Spill . . . . . . . . . . . . . . . . . 10

2.2.6 Corrective Action Site 04-99-02, Mud Spill . . . . . . . . . . . . . . . . . 12

2.2.7 Corrective Action Site 12-09-01, Mud Pit . . . . . . . . . . . . . . . . . . 12

2.2.8 Corrective Action Site 12-09-04, Mud Pit . . . . . . . . . . . . . . . . . 14

2.2.9 Corrective Action Site 12-09-08, Mud Pit . . . . . . . . . . . . . . . . . . . . 14

2.2.10 Corrective Action Site 12-30-14, Cellar. . . . . . . . . . . . . . . . . . . 16

2.2.11 Corrective Action Site 12-99-07, Mud Dump . . . . . . . . . . . . . . 17

2.2.12 Corrective Action Site 15-09-01, Mud Pit . . . . . . . . . . . . . . . 17

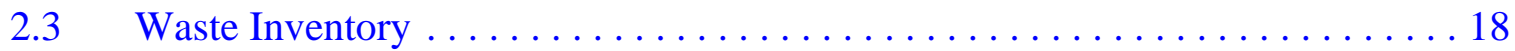

2.3.1 Corrective Action Site 02-09-48, Area 2 Mud Plant \#1 . . . . . . . . . . . 18

2.3.2 Corrective Action Site 02-09-49, Area 2 Mud Plant \#2 . . . . . . . . . . . . 19

2.3.3 Corrective Action Site 02-99-05, Mud Spill . . . . . . . . . . . . . . . . 19

2.3.4 Corrective Action Site 03-09-02, Mud Dump Trenches . . . . . . . . . . 19

2.3.5 Corrective Action Site 04-44-02, Mud Spill . . . . . . . . . . . . . . . . . . 19

2.3.6 Corrective Action Site 04-99-02, Mud Spill . . . . . . . . . . . . . . . . . . 19

2.3.7 Corrective Action Site 12-09-01, Mud Pit . . . . . . . . . . . . . . . . . 19

2.3.8 Corrective Action Site 12-09-04, Mud Pit . . . . . . . . . . . . . . . . . . . 20

2.3.9 Corrective Action Site 12-09-08, Mud Pit . . . . . . . . . . . . . . . . . . . 20

2.3.10 Corrective Action Site 12-30-14, Cellar. . . . . . . . . . . . . . . . . 20 


\section{Table of Contents (Continued)}

2.3.11 Corrective Action Site 12-99-07, Mud Dump . . . . . . . . . . . . 21

2.3.12 Corrective Action Site 15-09-01, Mud Pit . . . . . . . . . . . . . . 21

2.4 Release Information ... . . . . . . . . . . . . . . . . . . . 21

2.4.1 Corrective Action Site 02-09-48, Area 2 Mud Plant \#1 . . . . . . . . . . . 22

2.4.2 Corrective Action Site 02-09-49, Area 2 Mud Plant \#2 . . . . . . . . . . . 22

2.4.3 Corrective Action Site 02-99-05, Mud Spill . . . . . . . . . . . . . . . . 22

2.4.4 Corrective Action Site 03-09-02, Mud Dump Trenches . . . . . . . . . . . 22

2.4.5 Corrective Action Site 04-44-02, Mud Spill . . . . . . . . . . . . . . . . . 23

2.4.6 Corrective Action Site 04-99-02, Mud Spill . . . . . . . . . . . . . . . 23

2.4.7 Corrective Action Site 12-09-01, Mud Pit . . . . . . . . . . . . . . . . . 23

2.4 .8 Corrective Action Site 12-09-04, Mud Pit . . . . . . . . . . . . . . . . . 23

2.4.9 Corrective Action Site 12-09-08, Mud Pit . . . . . . . . . . . . . . . . 23

2.4.10 Corrective Action Site 12-30-14, Cellar. . . . . . . . . . . . . . . . . . . . 24

2.4.11 Corrective Action Site 12-99-07, Mud Dump . . . . . . . . . . . . . . 24

2.4 .12 Corrective Action Site 15-09-01, Mud Pit . . . . . . . . . . . . . . . . . 24

2.5 Investigative Background . . . . . . . . . . . . . . . . . 24

2.5.1 Corrective Action Site 02-09-48, Area 2 Mud Plant \#1 . . . . . . . . . . . 25

2.5.2 Corrective Action Site 02-09-49, Area 2 Mud Plant \#2 . . . . . . . . . . . 26

2.5.3 Corrective Action Site 02-99-05, Mud Spill . . . . . . . . . . . . . . . 26

2.5.4 Corrective Action Site 03-09-02, Mud Dump Trenches . . . . . . . . . . 26

2.5.5 Corrective Action Site 04-44-02, Mud Spill . . . . . . . . . . . . . . . 26

2.5.6 Corrective Action Site 04-99-02, Mud Spill . . . . . . . . . . . . . . . . 27

2.5.7 Corrective Action Site 12-09-01, Mud Pit . . . . . . . . . . . . . . . . . 27

2.5.8 Corrective Action Site 12-09-04, Mud Pit . . . . . . . . . . . . . . . . 27

2.5.9 Corrective Action Site 12-09-08, Mud Pit . . . . . . . . . . . . . . . . . 27

2.5.10 Corrective Action Site 12-30-14, Cellar. . . . . . . . . . . . . . . . . . . . 27

2.5.11 Corrective Action Site 12-99-07, Mud Dump . . . . . . . . . . . . . . . . 27

2.5.12 Corrective Action Site 15-09-01, Mud Pit . . . . . . . . . . . . . . . . . . . . 27

2.5.13 National Environmental Policy Act . . . . . . . . . . . . . . 28

2.6 CAS Categorization . . . . . . . . . . . . . . . . . . . 28

2.6.1 Corrective Action Site 02-09-48, Area 2 Mud Plant \#1 . . . . . . . . . . . 28

2.6.2 Corrective Action Site 02-09-49, Area 2 Mud Plant \#2 . . . . . . . . . . . 28

2.6.3 Corrective Action Site 02-99-05, Mud Spill . . . . . . . . . . . . . . . . . 28

2.6.4 Corrective Action Site 03-09-02, Mud Dump Trenches . . . . . . . . . . . 29

2.6 .5 Corrective Action Site 04-44-02, Mud Spill . . . . . . . . . . . . . . . . . . 29

2.6.6 Corrective Action Site 04-99-02, Mud Spill . . . . . . . . . . . . . . . . . 29

2.6.7 Corrective Action Site 12-09-01, Mud Pit . . . . . . . . . . . . . . . . . . . 29

2.6.8 Corrective Action Site 12-09-04, Mud Pit . . . . . . . . . . . . . . . . . 30

2.6.9 Corrective Action Site 12-09-08, Mud Pit . . . . . . . . . . . . . . . . . . 30

2.6.10 Corrective Action Site 12-30-14, Cellar. . . . . . . . . . . . . . . . . . . . . 30

2.6.11 Corrective Action Site 12-99-07, Mud Dump . . . . . . . . . . . . . . 30 


\section{Table of Contents (Continued)}

2.6.12 Corrective Action Site 15-09-01, Mud Pit .............. 30

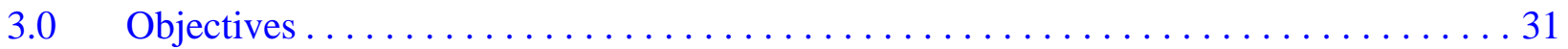

$3.1 \quad$ Conceptual Site Model . . . . . . . . . . . . . . . . . . . . . . . . . . 31

3.1.1 Land Use and Exposure Scenarios .................... 34

3.1.2 Contaminant Sources ............................. 34

3.1.3 Release Mechanisms ........................... 34

3.1.4 Migration Pathways . . . . . . . . . . . . . . . . . . . . 35

3.1.5 Exposure Points .............................. 36

3.1.6 Exposure Routes.............................. 36

3.1.7 Additional Information........................ 36

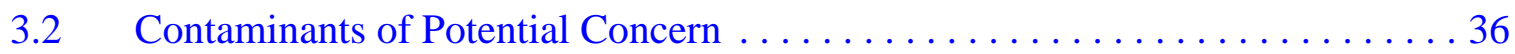

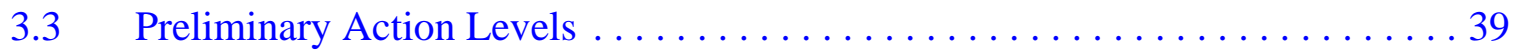

3.3.1 Chemical PALs............................... 41

3.3.2 Total Petroleum Hydrocarbon PALs . . . . . . . . . . . . . . 41

3.3.3 Radionuclide PALs.......................... 41

3.4 Data Quality Objective Process Discussion $\ldots \ldots \ldots \ldots \ldots \ldots \ldots \ldots \ldots 42$

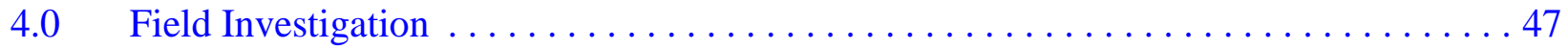

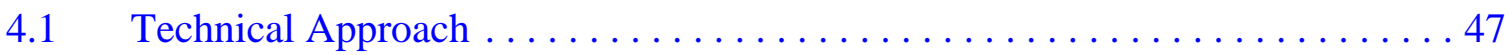

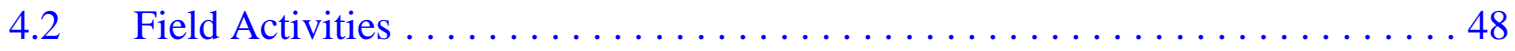

4.2.1 Site Preparation Activities . . . . . . . . . . . . . . . . . 48

4.2.2 Sample Location Selection....................... 48

4.2.3 Sample Collection .......................... 49

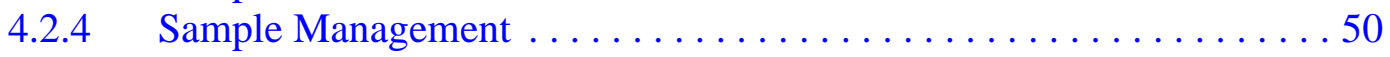

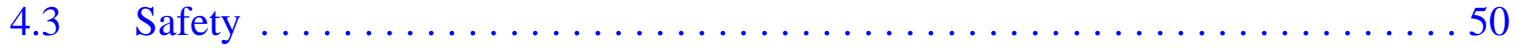

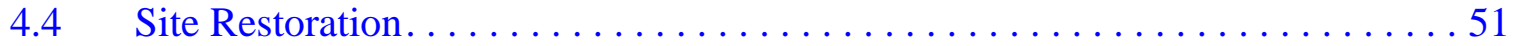

$5.0 \quad$ Waste Management........................................ 52

$5.1 \quad$ Waste Minimization ................................. 52

$5.2 \quad$ Potential Waste Streams ................................ 53

$5.3 \quad$ Investigation-Derived Waste Management $\ldots \ldots \ldots \ldots \ldots \ldots \ldots \ldots \ldots$

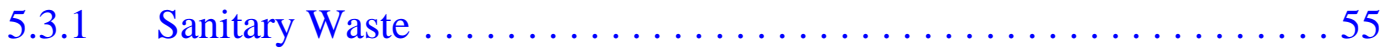

5.3.2 Low-Level Radioactive Waste . . . . . . . . . . . . . . . . . . . . 55

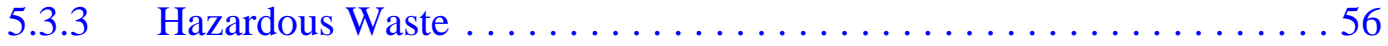

5.3 .4 Hydrocarbon Waste ............................ 56

5.3 .5 Mixed Low-Level Waste . . . . . . . . . . . . . . . . . . . 57

5.3.6 Polychlorinated Biphenyls . . . . . . . . . . . . . . . . . . 57

$5.4 \quad$ Management of Specific Waste Streams . . . . . . . . . . . . . . . . 58

5.4 .1 Personal Protective Equipment. ................... 58

5.4.2 Management of Decontamination Rinsate................. 58 


\section{Table of Contents (Continued)}

$5.4 .3 \quad$ Management of Soil ............................ 59

5.4 .4 Management of Debris ............................ 60

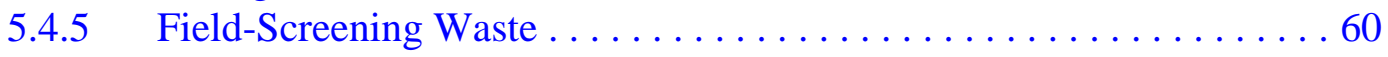

6.0 Quality Assurance/Quality Control $\ldots \ldots \ldots \ldots \ldots \ldots \ldots \ldots \ldots \ldots \ldots \ldots \ldots \ldots \ldots \ldots \ldots$

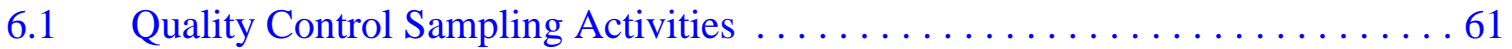

$6.2 \quad$ Laboratory/Analytical Quality Assurance $\ldots \ldots \ldots \ldots \ldots \ldots \ldots \ldots . \ldots 62$

6.2.1 Data Validation...............................62 62

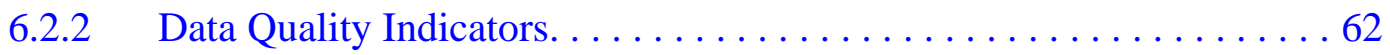

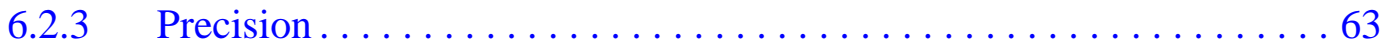

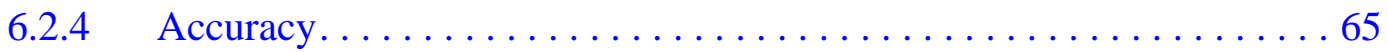

6.2 .5 Representativeness ........................66 66

6.2 .6 Completeness ..............................67 67

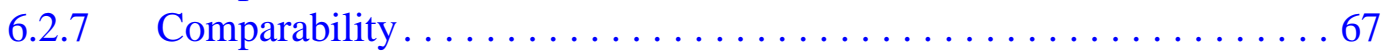

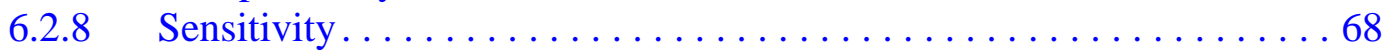

$7.0 \quad$ Duration and Records Availability . . . . . . . . . . . . . . . . . . . . . 69

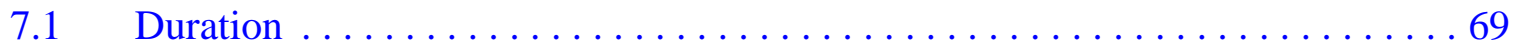

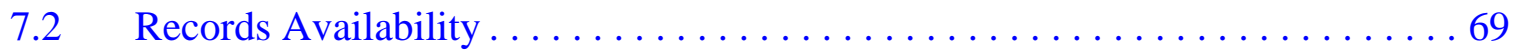

$8.0 \quad$ References..................................... 70

\section{Appendix A - Data Quality Objectives}

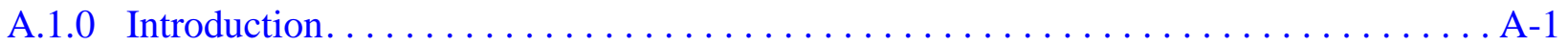

A.2.0 Background Information. ........................

A.2.1 Categorization of Corrective Action Sites in CAU $234 \ldots \ldots \ldots \ldots \ldots \ldots$. . . . . . . .

A.2.2 Corrective Action Site 02-09-48, Area 2 Mud Plant $\# 1 \ldots \ldots \ldots \ldots \ldots \ldots$. A-6

A.2.3 Corrective Action Site 02-09-49, Area 2 Mud Plant \#2 . . . . . . . . . . A-7

A.2.4 Corrective Action Site 02-99-05, Mud Spill. . . . . . . . . . . . . . . . A A-9

A.2.5 Corrective Action Site 03-09-02, Mud Dump Trenches. . . . . . . . . . . . A-10

A.2.6 Corrective Action Site 04-44-02, Mud Spill. . . . . . . . . . . . . . . . A-13

A.2.7 Corrective Action Site 04-99-02, Mud Spill. . . . . . . . . . . . . . . . . A-14

A.2.8 Corrective Action Site 12-09-01, Mud Pit . . . . . . . . . . . . . . . A-15

A.2.9 Corrective Action Site 12-09-04, Mud Pit . . . . . . . . . . . . . . . A-17

A.2.10 Corrective Action Site 12-09-08, Mud Pit . . . . . . . . . . . . . . . A-18

A.2.11 Corrective Action Site 12-30-14, Cellar . . . . . . . . . . . . . . A-20

A.2.12 Corrective Action Site 12-99-07, Mud Dump . . . . . . . . . . . . . . A-21

A.2.13 Corrective Action Site 15-09-01, Mud Pit . . . . . . . . . . . . . . A-22

A.3.0 Step 1 - State the Problem.............................. A-24 


\section{Table of Contents (Continued)}

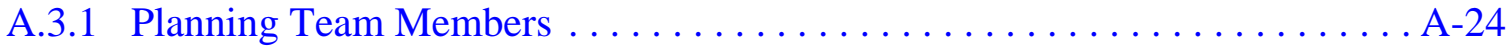

A.3.2 Conceptual Site Model ................................ A-24

A.3.2.1 Contaminant Release .......................... A-25

A.3.2.2 Potential Contaminants. ...................... A-28

A.3.2.3 Contaminant Characteristics...................... A-28

A.3.2.4 Site Characteristics ........................... A-29

A.3.2.5 Migration Pathways and Transport Mechanisms........... A-30

A.3.2.6 Exposure Scenarios . . . . . . . . . . . . . . . . . A-30

A.4.0 Step 2 - Identify the Goal of the Study ....................... A-32

A.4.1 Decision Statements . . . . . . . . . . . . . . . . . . . . . . A-32

A.4.2 Alternative Actions to the Decisions $\ldots \ldots \ldots \ldots \ldots \ldots \ldots \ldots \ldots$ A-33

A.4.2.1 Alternative Actions to Decision I. . . . . . . . . . . . . . A-33

A.4.2.2 Alternative Actions to Decision II . . . . . . . . . . . . . . A-33

A.5.0 Step 3 - Identify Information Inputs . . . . . . . . . . . . . . . . . . A-34

A.5.1 Information Needs . . . . . . . . . . . . . . . . . . . . . . A-34

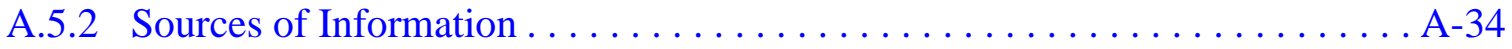

A.5.2.1 Sample Locations ............................ A-35

A.5.2.2 Analytical Methods $\ldots \ldots \ldots \ldots \ldots \ldots \ldots \ldots \ldots \ldots \ldots \ldots \ldots \ldots$

A.6.0 Step 4 - Define the Boundaries of the Study $\ldots \ldots \ldots \ldots \ldots \ldots \ldots \ldots \ldots$ A-37

A.6.1 Target Populations of Interest. . . . . . . . . . . . . . . . . . . . .

A.6.2 Spatial Boundaries ............................. A-37

A.6.3 Practical Constraints ................................ A

A.6.4 Define the Sampling Units . . . . . . . . . . . . . . . . . . . . A 38

A.7.0 Step 5 - Develop the Analytic Approach ....................... A-39

A.7.1 Population Parameters $\ldots \ldots \ldots \ldots \ldots \ldots \ldots \ldots \ldots \ldots \ldots \ldots \ldots$. A-39

A.7.2 Action Levels . ................................ A-39

A.7.2.1 Chemical PALs.............................. A-40

A.7.2.2 Total Petroleum Hydrocarbon PALs $\ldots \ldots \ldots \ldots \ldots \ldots \ldots$. A-41

A.7.2.3 Radionuclide PALs. . . . . . . . . . . . . . . . . . . A-41

A.7.3 Decision Rules .................................. A-41

A.8.0 Step 6 - Specify Performance or Acceptance Criteria . . . . . . . . . . . . . . A-43

A.8.1 Decision Hypotheses. . . . . . . . . . . . . . . . . . . . . . . . .

A.8.2 False Negative Decision Error $\ldots \ldots \ldots \ldots \ldots \ldots \ldots \ldots \ldots \ldots \ldots \ldots . \ldots \ldots$

A.8.3 False Positive Decision Error . . . . . . . . . . . . . . . . . . . A-46

A.9.0 Step 7 - Develop the Plan for Obtaining Data $\ldots \ldots \ldots \ldots \ldots \ldots \ldots \ldots$ A-47 


\section{Table of Contents (Continued)}

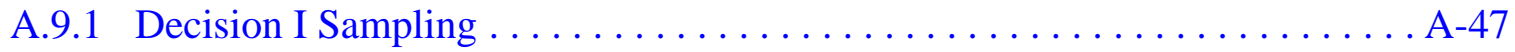

A.9.2 Decision II Sampling . . . . . . . . . . . . . . . . . . . . . . A-48

A.9.3 Corrective Action Site 02-09-48, Area 2 Mud Plant \#1 . . . . . . . . . . . . . . . A-48

A.9.4 Corrective Action Site 03-09-02, Mud Dump Trenches. . . . . . . . . . . . . . A-49

A.9.5 Corrective Action Site 12-09-01, Mud Pit . . . . . . . . . . . . . . . . A-50

A.9.6 Corrective Action Site 12-09-08, Mud Pit . . . . . . . . . . . . . . . . . . A-52

A.9.7 Corrective Action Site 12-30-14, Cellar. . . . . . . . . . . . . . . . A-54

A.10.0 References................................... A-55

Appendix B - Project Organization

B.1.0 Project Organization . . . . . . . . . . . . . . . . . . . . . . .

Appendix C - Nevada Division of Environmental Protection Comment Responses 


\section{List of Figures}

Number

1-1 Nevada Test Site Map with CAU 234 CAS Locations .................... 2

2-1 Corrective Action Site $02-09-48 \ldots \ldots \ldots \ldots \ldots \ldots \ldots \ldots \ldots$

2-2 Corrective Action Site 02-09-49 ........................ 9

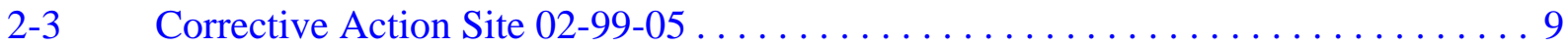

2-4 Suction Pit in Northern Footprint, CAS 03-09-02, Mud Dump Trenches . . . . . . 10

2-5 Mud Pit in Northern Footprint, CAS 03-09-02, Mud Dump Trenches.......... 11

2-6 Mud Pits in Southern Footprint, CAS 03-09-02, Mud Dump Trenches ......... 11

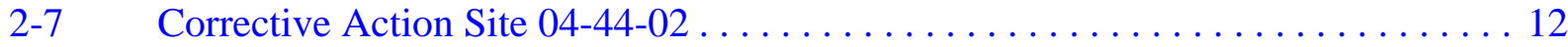

2-8 Spill Site C at Corrective Action Site 04-99-02 ................. 13

2-9 Mud Pit at Corrective Action Site $12-09-01 \ldots \ldots \ldots \ldots \ldots \ldots \ldots \ldots \ldots \ldots$

2-10 Debris at CAS 12-09-01, Mud Pit........................... 14

2-11 Mud Pit with Crater in Background at CAS 12-09-04, Mud Pit............ 15

2-12 Pipe and Crushed Drums at CAS 12-09-08, Mud Pit ................ 15

2-13 Corrective Action Site 12-30-14, Cellar . . . . . . . . . . . . . . . . . 16

2-14 Corrective Action Site 12-99-07, Mud Dump................... 17

2-15 Corrective Action Site 15-09-01, Mud Pit ..................... 18

3-1 Conceptual Site Model Diagram........................... 32

3-2 Corrective Action Unit 234 Conceptual Site Model ...................... . 33

3-3 Risk-Based Corrective Action Decision Process ................... 40 


\section{List of Figures (Continued)}

Number

Title

Page

A.2-1 Nevada Test Site Map with CAU 234 CAS Locations . . . . . . . . . . . . A-4

A.2-2 Corrective Action Site 02-09-48, Area 2 Mud Plant $\# 1 \ldots \ldots \ldots \ldots \ldots \ldots$. . . A-7

A.2-3 Corrective Action Site 02-09-49, Area 2 Mud Plant $\# 2 \ldots \ldots \ldots \ldots \ldots \ldots$. . . .

A.2-4 Corrective Action Site 02-99-05, Mud Spill . . . . . . . . . . . . . . . A-9

A.2-5 Suction Pit in Northern Footprint of CAS $03-09-02 \ldots \ldots \ldots \ldots \ldots \ldots \ldots \ldots$ A-11

A.2-6 Mud Pit in Northern Footprint of CAS 03-09-02 . . . . . . . . . . . . A A-12

A.2-7 Mud Pits in Southern Footprint of CAS $03-09-02 \ldots \ldots \ldots \ldots \ldots \ldots \ldots$. . . . . .

A.2-8 Corrective Action Site 04-44-02, Mud Spill . . . . . . . . . . . . . . . A-13

A.2-9 Spill Site C at CAS 04-99-02, Mud Spill . . . . . . . . . . . . . A-15

A.2-10 Mud Pit Footprint in CAS 12-09-01, Mud Pit. . . . . . . . . . . . . A-16

A.2-11 Debris at CAS 12-09-01, Mud Pit .................. A-16

A.2-12 Corrective Action Site 12-09-04, Mud Pit . . . . . . . . . . . . . A-18

A.2-13 Corrective Action Site 12-09-08, Mud Pit . . . . . . . . . . . . A-19

A.2-14 Corrective Action Site 12-30-14, Cellar . . . . . . . . . . . . . . . . A-20

A.2-15 Corrective Action Site 12-99-07, Mud Dump . . . . . . . . . . . . A-21

A.2-16 Corrective Action Site 15-09-01, Mud Pit . . . . . . . . . . . . . A-22

A.3-1 Conceptual Site Model for CAU $234 \ldots \ldots \ldots \ldots \ldots \ldots \ldots \ldots \ldots \ldots$. . $\ldots \ldots$

A.9-1 Proposed Sample Location at CAS $02-09-48 \ldots \ldots \ldots \ldots \ldots \ldots \ldots \ldots \ldots$ A-49

A.9-2 Proposed Suction Pit Sample Location(s) at CAS 03-09-02 . . . . . . . . . A-50 


\section{List of Figures (Continued)}

Number

Title

Page

A.9-3 Proposed Mud Pit Sample Location at CAS 03-09-02 . . . . . . . . . . . A-51

A.9-4 Proposed Borrow Pit Sample Locations at CAS 03-09-02 . . . . . . . . . . . . A-51

A.9-5 Proposed Sample Locations at CAS $12-09-01 \ldots \ldots \ldots \ldots \ldots \ldots \ldots$ A-52

A.9-6 Proposed Sample Locations at CAS $12-09-08 \ldots \ldots \ldots \ldots \ldots \ldots \ldots$ A-53

A.9-7 Proposed Sample Location at CAS $12-30-14 \ldots \ldots \ldots \ldots \ldots \ldots \ldots \ldots$ A-54 


\section{List of Tables}

Number

Title

Page

2-1 Corrective Action Site Categorization for CAU $234 \ldots \ldots \ldots \ldots \ldots \ldots$

3-1 Analytical Program....................................... 37

3-2 Constituents Reported by Analytical Methods ...................... 38

3-3 Analytical Requirements for Radionuclides for CAU $234 \ldots \ldots \ldots \ldots \ldots \ldots 44$

3-4 Analytical Requirements for Chemical COPCs for CAU $234 \ldots \ldots \ldots \ldots \ldots 45$

5-1 Waste Management Regulations and Requirements ................. 54

6-1 Laboratory and Analytical Performance Criteria for CAU 234 Data Quality Indicators ........................... 64

7-1 Corrective Action Investigation Activity Durations................. 69

A.2-1 Corrective Action Site Categorization for CAU $234 \ldots \ldots \ldots \ldots \ldots$. . . 6

A.3-1 Conceptual Site Model Description of Elements for Each CAU 234 CAS . . . A-26

A.3-2 Analytical Program (Includes Waste Characterization Analyses) . . . . . . . A A-29

A.3-3 Land-Use and Exposure Scenarios for Category III CASs. . . . . . . . . . A-31

A.6-1 Spatial Boundaries of CAU 234 CASs...................... A-38

A.6-2 Practical Constraints for the CAU 234 Field Investigation $\ldots \ldots \ldots \ldots \ldots$ A-38 


\section{List of Acronyms and Abbreviations}

ASTM American Society for Testing and Materials

bgs Below ground surface

CADD Corrective Action Decision Document

CAI Corrective Action Investigation

CAIP Corrective Action Investigation Plan

CAS Corrective Action Site

CAU Corrective Action Unit

CERCLA Comprehensive Environmental Response, Compensation, and Liability Act

CFR $\quad$ Code of Federal Regulations

COC Contaminant of concern

COPC Contaminant of potential concern

CR Closure Report

CSM Conceptual site model

DOE U.S. Department of Energy

DOT U.S. Department of Transportation

DQI Data quality indicator

DQO Data quality objective

DRO Diesel-range organics

EPA U.S. Environmental Protection Agency

FAL Final action level

FFACO Federal Facility Agreement and Consent Order

$\mathrm{ft} \quad$ Foot

gal Gallon

HASL Health and Safety Laboratory 


\title{
List of Acronyms and Abbreviations (Continued)
}

\author{
HWAA Hazardous waste accumulation area \\ IDW Investigation-derived waste \\ in. Inch \\ ISMS Integrated Safety Management System \\ LCS Laboratory control sample \\ LCSD Laboratory control sample duplicate \\ MDC Minimum detectable concentration \\ mi Mile \\ MLLW $\quad$ Mixed low-level waste \\ $\mathrm{mm} / \mathrm{yr} \quad$ Millimeters per year \\ mrem/yr Millirem per year \\ MS Matrix spike \\ N/A Not applicable \\ NAC Nevada Administrative Code \\ NCRP National Council on Radiation Protection and Measurement \\ ND Normalized difference \\ NDEP Nevada Division of Environmental Protection \\ NEPA National Environmental Policy Act \\ NNSA/NSO U.S. Department of Energy, National Nuclear Security Administration Nevada \\ Site Office \\ NRS Nevada Revised Statutes \\ NSTec National Security Technologies, LLC \\ NTS Nevada Test Site \\ NTSWAC Nevada Test Site Waste Acceptance Criteria
}




\section{List of Acronyms and Abbreviations (Continued)}

\begin{tabular}{|c|c|}
\hline NV/YMP & Nevada Yucca Mountain Project \\
\hline PAL & Preliminary action level \\
\hline PCB & Polychlorinated biphenyl \\
\hline $\mathrm{pCi} / \mathrm{L}$ & Picocuries per liter \\
\hline POC & Performance Objective for the Certification of Nonradioactive Hazardous Waste \\
\hline PPE & Personal protective equipment \\
\hline ppm & Parts per million \\
\hline PRG & Preliminary remediation goal \\
\hline QA & Quality assurance \\
\hline QAPP & Quality Assurance Project Plan \\
\hline QC & Quality control \\
\hline RadCon & Radiological control \\
\hline RBCA & Risk-based corrective action \\
\hline RCA & Radiologically controlled area \\
\hline RCRA & Resource Conservation and Recovery Act \\
\hline RESRAD & Residual Radioactive \\
\hline RL & Reporting limit \\
\hline RMA & Radioactive material area \\
\hline RPD & Relative percent difference \\
\hline SAA & Satellite accumulation area \\
\hline SNJV & Stoller-Navarro Joint Venture \\
\hline SSTL & Site-specific target level \\
\hline SVOC & Semivolatile organic compound \\
\hline TPH & Total petroleum hydrocarbons \\
\hline
\end{tabular}




\section{List of Acronyms and Abbreviations (Continued)}

TSCA Toxic Substances Control Act

UGTA Underground Test Area

USGS U.S. Geological Survey

VOC Volatile organic compound

WW-2 Water Well 2

$\%$ Percent recovery 


\section{Executive Summary}

Corrective Action Unit 234 is located in Areas 2, 3, 4, 12, and 15 of the Nevada Test Site, approximately 65 miles northwest of Las Vegas, Nevada. Corrective Action Unit 234 is comprised of the 12 Corrective Action Sites (CASs) listed below:

- 02-09-48, Area 2 Mud Plant \#1

- 02-09-49, Area 2 Mud Plant \#2

- 02-99-05, Mud Spill

- 03-09-02, Mud Dump Trenches

- 04-44-02, Mud Spill

- 04-99-02, Mud Spill

- 12-09-01, Mud Pit

- 12-09-04, Mud Pit

- 12-09-08, Mud Pit

- 12-30-14, Cellar

- 12-99-07, Mud Dump

- 15-09-01, Mud Pit

These sites are being investigated because existing information on the nature and extent of potential contamination is insufficient to evaluate and recommend corrective action alternatives. Additional information will be obtained by conducting a corrective action investigation (CAI) before evaluating corrective action alternatives and selecting the appropriate corrective action for each CAS. The results of the field investigation will support a defensible evaluation of viable corrective action alternatives that will be presented in the Corrective Action Decision Document.

The sites will be investigated based on the data quality objectives (DQOs) developed on April 12, 2007, by representatives of the Nevada Division of Environmental Protection, U.S. Department of Energy (DOE), National Nuclear Security Administration Nevada Site Office; Stoller-Navarro Joint Venture; and National Security Technologies, LLC. The DQO process was used to identify and define the type, amount, and quality of data needed to develop and evaluate appropriate corrective actions for CAU 234.

Appendix A provides a detailed discussion of the DQO methodology and the DQOs specific to each CAS. 
The scope of the CAI for CAU 234 includes the following activities:

- Move surface debris and/or materials, as needed, to facilitate sampling.

- Conduct radiological surveys.

- $\quad$ Perform field screening.

- Collect and submit environmental samples for laboratory analysis to determine whether contaminants of concern are present.

- If contaminants of concern are present, collect additional step-out samples to define the extent of the contamination.

- Collect samples of investigation-derived waste, as needed, for waste management purposes.

This Corrective Action Investigation Plan has been developed in accordance with the Federal Facility Agreement and Consent Order that was agreed to by the State of Nevada; DOE, Environmental Management; U.S. Department of Defense; and DOE, Legacy Management. Under the Federal Facility Agreement and Consent Order, this Corrective Action Investigation Plan will be submitted to the Nevada Division of Environmental Protection for approval. Fieldwork will be conducted following approval of the plan. 


\subsection{Introduction}

This Corrective Action Investigation Plan (CAIP) contains project-specific information including facility descriptions, environmental sample collection objectives, and criteria for conducting site investigation activities at Corrective Action Unit (CAU) 234: Mud Pits, Cellars, and Mud Spills, Nevada Test Site (NTS), Nevada.

This CAIP has been developed in accordance with the Federal Facility Agreement and Consent Order (FFACO) that was agreed to by the State of Nevada; U.S. Department of Energy (DOE), Environmental Management; U.S. Department of Defense; and DOE, Legacy Management (FFACO, 1996; as amended August 2006).

Corrective Action Unit 234 is located in Areas 2, 3, 4, 12, and 15 of the NTS, approximately 65 miles (mi) northwest of Las Vegas, Nevada (Figure 1-1). Corrective Action Unit 234 is comprised of the 12 Corrective Action Sites (CASs) shown on Figure 1-1 and listed below:

- 02-09-48, Area 2 Mud Plant \#1

- 02-09-49, Area 2 Mud Plant \#2

- 02-99-05, Mud Spill

- 03-09-02, Mud Dump Trenches

- 04-44-02, Mud Spill

- 04-99-02, Mud Spill

- 12-09-01, Mud Pit

- 12-09-04, Mud Pit

- 12-09-08, Mud Pit

- 12-30-14, Cellar

- 12-99-07, Mud Dump

- 15-09-01, Mud Pit

The Corrective Action Investigation (CAI) will include field inspections, radiological surveys, sampling of environmental media, analysis of samples, and assessment of investigation results where appropriate. Data will be obtained to support corrective action alternative evaluations and waste management decisions. 


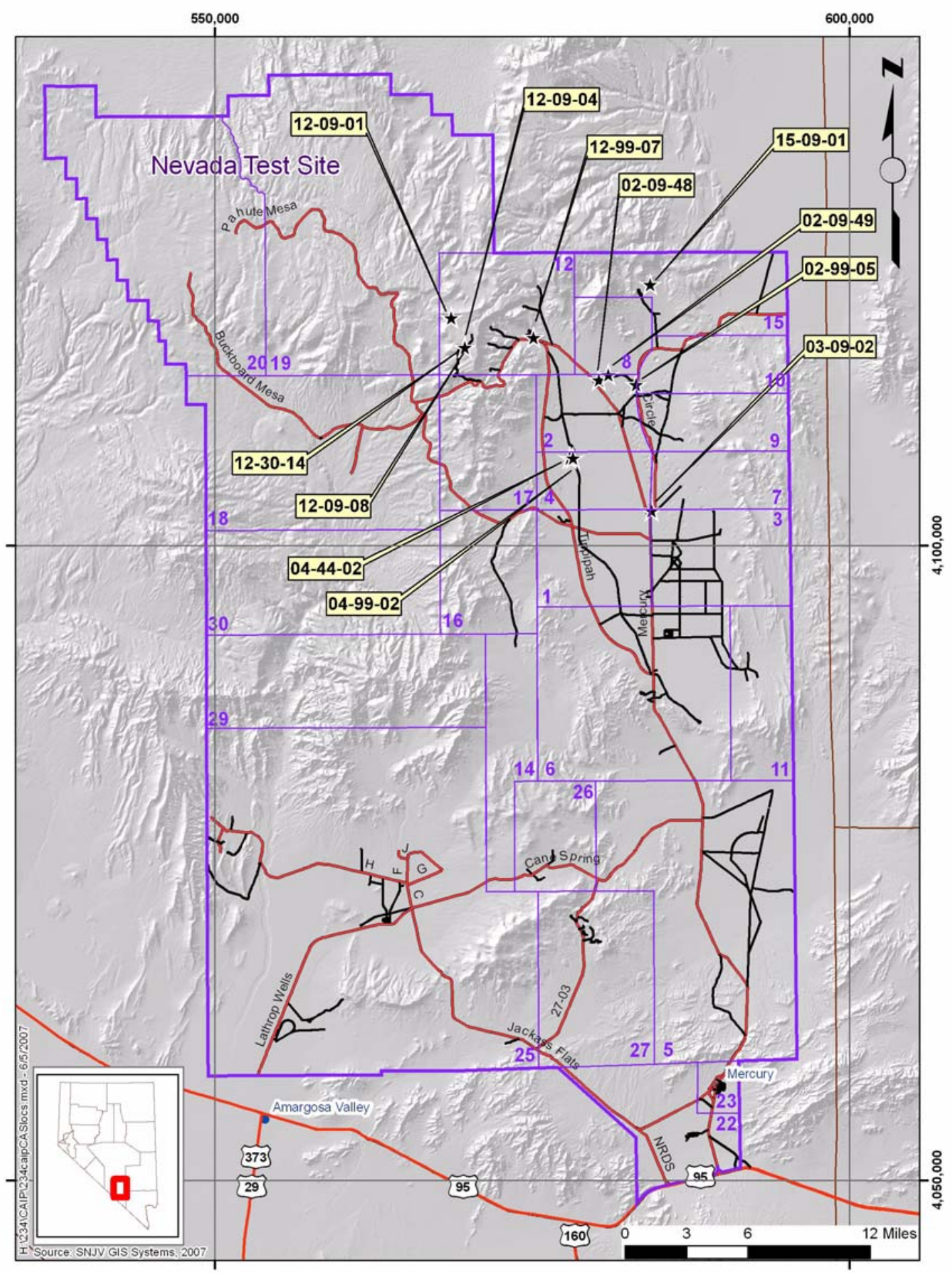

Figure 1-1

Nevada Test Site Map with CAU 234 CAS Locations 


\subsection{Purpose}

The CASs in CAU 234 are being investigated because hazardous and/or radioactive constituents may be present in concentrations that could potentially pose a threat to human health and the environment. Existing information on the nature and extent of potential contamination is insufficient to evaluate and recommend corrective action alternatives for the CASs. Additional information will be generated by conducting a CAI before evaluating and selecting appropriate corrective action alternatives.

\subsubsection{Corrective Action Unit 234 History and Description}

Corrective Action Unit 234, Mud Pits, Cellars, and Mud Spills, consists of 12 inactive sites located in the north and northeast section of the NTS. The 12 CAU 234 sites consist of mud pits, mud spills, mud sumps, and an open post-test cellar. The CAU 234 sites were all used to support nuclear testing conducted in the Yucca Flat and Rainier Mesa areas during the 1950s through the 1970s. Operational histories for each CAU 234 CAS are detailed in Section 2.2.

\subsubsection{Data Quality Objective Summary}

The sites will be investigated based on data quality objectives (DQOs) developed by representatives of the Nevada Division of Environmental Protection (NDEP); DOE, National Nuclear Security Administration Nevada Site Office (NNSA/NSO); Stoller-Navarro Joint Venture (SNJV); and National Security Technologies, LLC (NSTec). The DQOs are used to identify and define the type, amount, and quality of data needed to develop and evaluate appropriate corrective actions for CAU 234. This CAIP describes the investigative approach developed to collect the data needs identified in the DQO process. A detailed discussion of the DQO methodology and the DQOs specific to each CAS is presented in Appendix A of this document and a summary of the DQO process is provided below.

The DQO problem statement for CAU 234 is: "Existing information on the nature and extent of potential contamination is insufficient to evaluate and recommend corrective action alternatives for the CASs in CAU 234.” To address this question, the resolution of two decisions statements is required: 
- Decision I: "Is any contaminant of potential concern (COPC) associated with the CAS present in environmental media at a concentration exceeding its corresponding final action level (FAL)?” For judgmental sampling, any contaminant associated with a CAS activity that is present at concentrations exceeding its corresponding FAL will be defined as a contaminant of concern (COC). A COC may also be defined as a contaminant that, in combination with other like contaminants, is determined to jointly pose an unacceptable risk based on a multiple constituent analysis (NNSA/NSO, 2006b). If a COC is detected, then Decision II must be resolved. If a COC is not detected, the investigation for that CAS is complete.

- Decision II: “If a COC is present, is sufficient information available to evaluate potential corrective action alternatives? Sufficient information is defined to include:

- Identifying the lateral and vertical extent of COC contamination in media.

- The information needed to determine potential remediation waste types.

- The information needed to evaluate the feasibility of remediation alternatives.

The informational inputs and data needs to resolve the problem statement and the decision statements were generated as part of the DQO process for this CAU and are documented in Appendix A. The information necessary to resolve the DQO decisions will be generated for each CAU 234 CAS that will undergo investigation by collecting and analyzing samples generated during a field investigation. The presence of contamination at each CAS will be determined by collecting and analyzing samples in areas most likely to contain a COC.

\subsection{Scope}

To generate information needed to resolve the decision statements identified in the DQO processes, the scope of the CAI for CAU 234 CASs that will undergo investigation includes the following activities:

- $\quad$ Move surface debris and/or materials, as needed, to facilitate sampling.

- Conduct radiological surveys.

- $\quad$ Perform field screening.

- Collect and submit environmental samples for laboratory analysis to determine the nature and extent of any contamination released by each CAS.

- Collect samples of source material to determine the potential for a release. 
- Collect samples of investigation-derived waste (IDW), as needed, for waste management and minimization purposes.

- Collect quality control (QC) samples.

Contamination of environmental media originating from activities not identified in the conceptual site model (CSM) of any CAS will not be considered as part of this CAU unless the CSM and the DQOs are modified to include the release. If not included in the CSM, contamination originating from these sources will not be considered for sample location selection, and/or will not be considered COCs. If such contamination is present, the contamination will be identified as part of another CAS (either new or existing).

\subsubsection{Categorization Strategy}

An evaluation of the characterization of each CAS, based on the potential for release of hazardous constituents listed, is provided in Section 2.4 and the results of previous investigations listed in Section 2.5 is used as a basis for CAS categorization presented in Section 2.6.

\subsection{Corrective Action Investigation Plan Contents}

Section 1.0 presents the purpose and scope of this CAIP, while Section 2.0 provides background information about CAU 234. Objectives of the investigation, including CSMs, are presented in Section 3.0. Field investigation and sampling activities are discussed in Section 4.0, and waste management issues for this project are discussed in Section 5.0. General field and laboratory quality assurance (QA) (including collection of QA samples) are presented in Section 6.0 and in the Industrial Sites Quality Assurance Project Plan (QAPP) (NNSA/NV, 2002a). The project schedule and records availability are discussed in Section 7.0. Section 8.0 provides a list of references.

Appendix A provides a detailed discussion of the DQO methodology and the DQOs specific to each CAS. Appendix B contains information on the project organization. Appendix C contains responses to NDEP comments on the draft version of this document. 


\subsection{Facility Description}

Corrective Action Unit 234 is comprised of 12 CASs that were grouped together based on technical similarities (mud pits, mud spills, cellars).

\subsection{Physical Setting}

The following sections describe the general physical settings of Areas 2, 3, and 12 of the NTS where CAS investigations will occur (see Section 1.2.1). General background information pertaining to topography, geology, hydrogeology, and climatology are provided for these specific areas of the NTS region in the Geologic Map of the Nevada Test Site, Southern Nevada (USGS, 1990); CERCLA Preliminary Assessment of DOE's Nevada Operations Office Nuclear Weapons Testing Areas (DRI, 1988); Final Environmental Impact Statement, Nevada Test Site, Nye County, Nevada (ERDA, 1977); and the Final Environmental Impact Statement for the Nevada Test Site and Off-Site Locations in the State of Nevada (DOE/NV, 1996).

\subsubsection{Yucca Flat}

Corrective Action Sites 02-09-48 and 03-09-02 are located within the Yucca Flat Hydrographic Area of the NTS. Yucca Flat is a closed basin, which is slowly being filled with alluvial deposits eroding from the surrounding mountains (USGS, 1996).

The direction of groundwater flow in Yucca Flat is generally northeast to southwest. Within the overlying alluvial and volcanic aquifers, lateral groundwater flow occurs from the margins to the center of the basin and downward into the carbonate aquifer (USGS, 1996). The average annual precipitation at Station UCC on the Yucca Flat dry lake is 6.62 inches (in.) (NOAA, 2002). The recharge rate to the Yucca Flat area is relatively low (1.76 millimeters per year [mm/yr]), and the thickness of the unsaturated zone extends to more than 600 feet (ft) below ground surface (bgs) (USGS, 1996).

The nearest groundwater well to CAS 02-09-48 is Water Well-2 (WW-2), an active well located approximately $0.5 \mathrm{mi}$ to the northeast of this site. The most recent recorded depth to the water table is approximately 2,053 ft bgs (USGS, 2006). The nearest well to CAS 03-09-02 is U.S. Geological 
Survey (USGS) Water Well UE-3e \#4, an inactive well located approximately $400 \mathrm{ft}$ northeast of the site. The most recent recorded depth to the water table is approximately 1,175 ft bgs (USGS, 2006).

\subsubsection{Rainier Mesa}

Corrective Action Sites 12-09-01, 12-09-08, and 12-30-14 are located within the NTS in Area 12 on the eastern slope of the Rainier Mesa. Groundwater beneath Rainier Mesa flows within the Alkali Flat-Furnace Creek Ranch subbasin (Laczniak et al.,1996).

The nearest well to CASs 12-09-01, 12-09-08, and 12-30-14 is ER12-3, located at an elevation of 7,385 ft and approximately 5,800 ft southeast of the site marker for CASs 12-09-01, 3,200 ft to the north from CAS 12-09-08, and 5,800 ft to the southeast from CAS 12-30-14. The well depth is $4,880 \mathrm{ft}$ and the depth to groundwater is 3,110 ft as of July 2006 (USGS/DOE, 2006). The Rainier Mesa rain gauge is located approximately $2.3 \mathrm{mi}$ southeast of CAS 12-09-01 at an elevation of 7,490 ft. Average total annual precipitation at A12 is 12.82 in (ARL/SORD, 2007).

\subsection{Operational History}

The following subsections provide a description of the use and history of each CAS in CAU 234 that may have resulted in potential releases to the environment. The CAS-specific summaries are designed to describe the current definition of each CAS and illustrate all significant, known activities.

\subsubsection{Corrective Action Site 02-09-48, Area 2 Mud Plant \#1}

This CAS is the mud sump adjacent to the Area 2 Mud Plant containing unused drilling mud. The Area 2 Mud Plant was operational from the mid-1960s until the early 1990s when the facility was closed. The main operations building has been demolished and/or removed. Figure 2-1 shows the location of an empty drum that was discovered within the mud sump. The sump was used for the storage of drilling muds produced at the mud plant before use in drilling operations at various NTS locations. The drilling muds were typically composed of powdered bentonite clay mixed with water. Use of the drum before mud sump placement is unknown. 


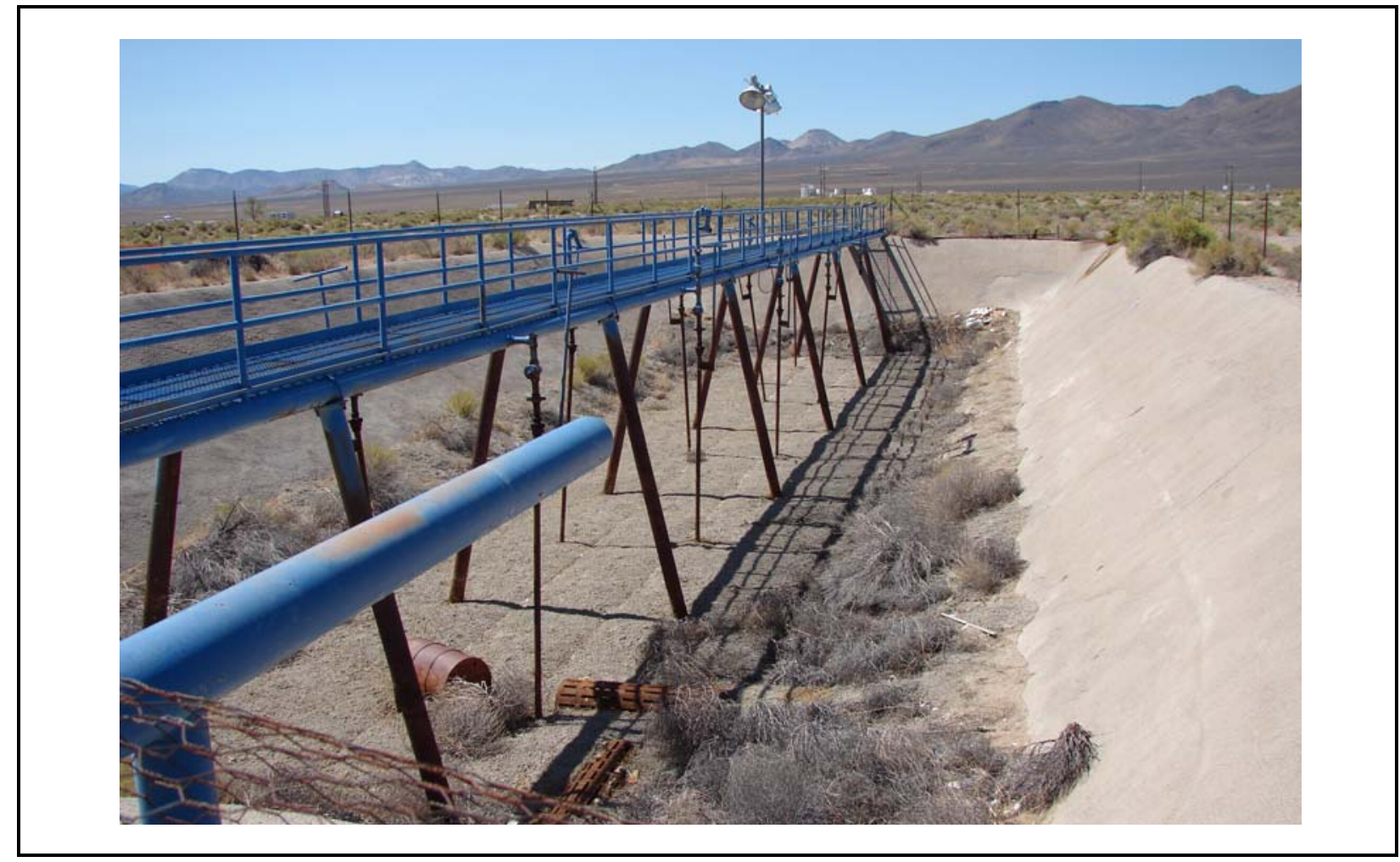

Figure 2-1

Corrective Action Site 02-09-48

\subsubsection{Corrective Action Site 02-09-49, Area 2 Mud Plant \#2}

Corrective Action Site 02-09-49 consists of a concrete-lined sump once used for the storage of water at the Area 2 Mud Plant \#2. It now contains unused drilling muds. The Area 2 Mud Plant was operational from the mid-1960s until the early 1990s when the facility was closed. The main operations building has been demolished and/or removed. No other potential releases are associated with CAS 02-09-49. Figure 2-2 is a photograph of this CAS.

\subsubsection{Corrective Action Site 02-99-05, Mud Spill}

Corrective Action Site CAS 02-99-05 consists of a pile of concrete misidentified as a mud spill. The concrete pile appears to be left over from legacy grouting operations at the U-2bp-2 PS \#1A cellar. It is unknown when the grouting operation was conducted at the post-test cellar, but it is believed that the concrete was excess and dumped by a vehicle delivering concrete for grouting. Figure 2-3 is a photograph of the cement pile at this CAS. 


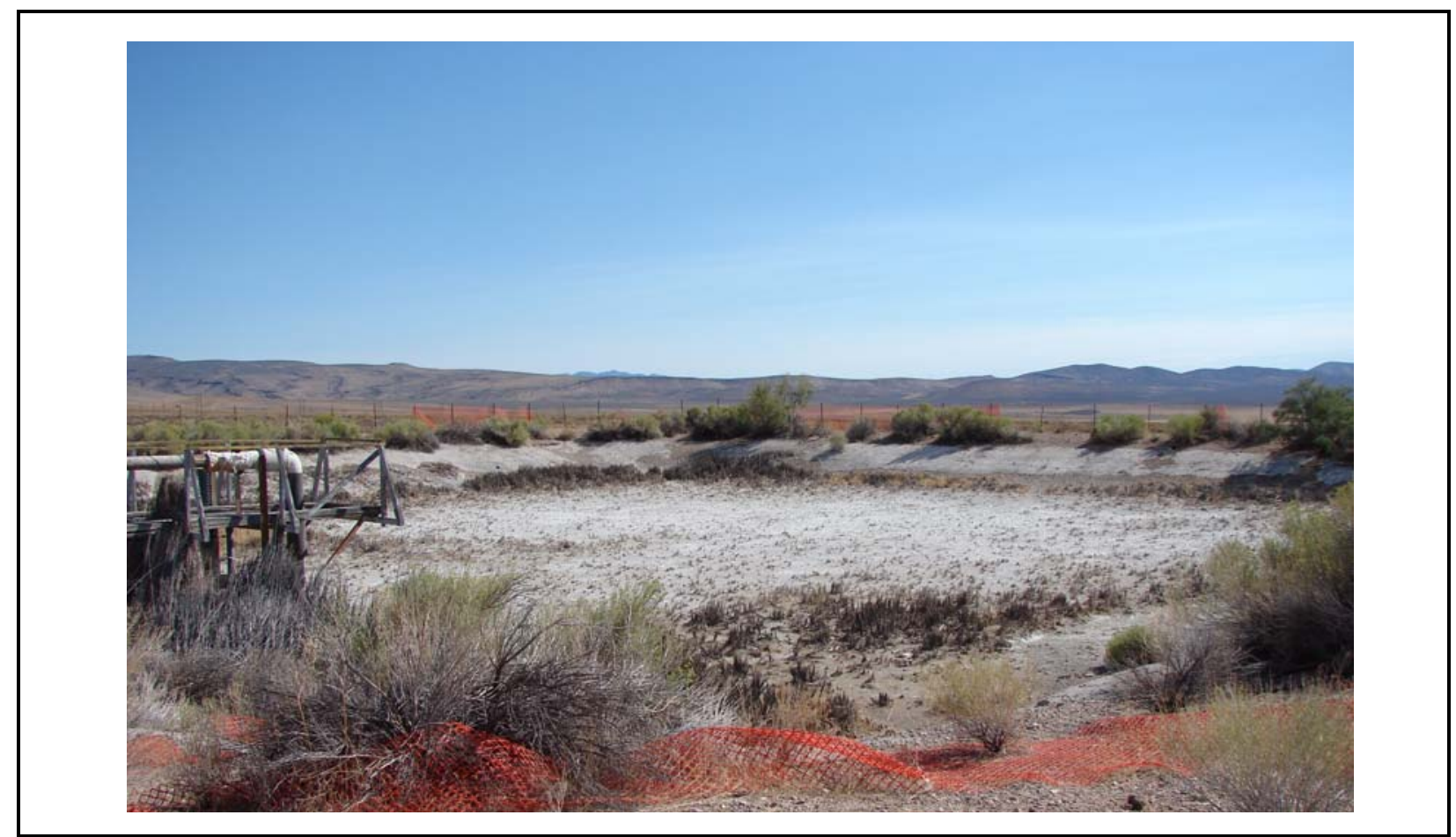

Figure 2-2

Corrective Action Site 02-09-49

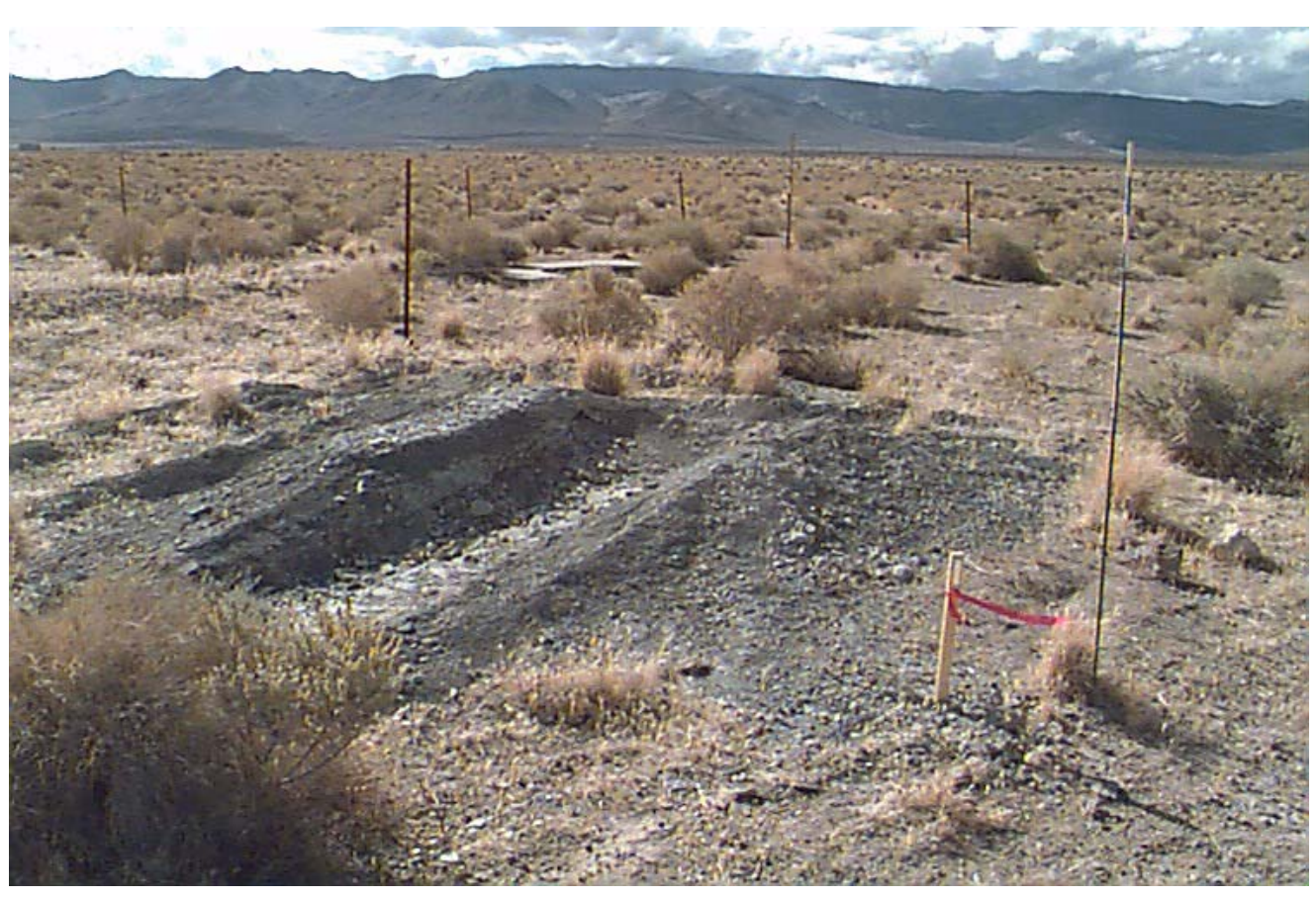

Figure 2-3

Corrective Action Site 02-99-05 


\subsubsection{Corrective Action Site 03-09-02, Mud Dump Trenches}

Corrective Action Site 03-09-02 is associated with the drilling of emplacement hole U-3kz in June 1984. This hole intercepted a radiologically contaminated plume from the Sandreef test conducted in November 1977. The drilling mud used for the U-3kz emplacement hole that intercepted the underground plume was believed to have been brought to the surface and placed in the mud pits within CAS 03-09-02. Figures 2-4 through 2-6 show the mud pit configuration at this CAS, which consists of a suction pit, mud pit, and two mud trenches.

\subsubsection{Corrective Action Site 04-44-02, Mud Spill}

Corrective Action Site 04-44-02 consists of spilled drilling mud associated with the drilling of the U-4at PS \#1A post-test cellar. The drilling mud is thinly spread over an area approximately 50 by $40 \mathrm{ft}$. The CAS is the potential release of contaminants to the surrounding soils from the spilled drilling mud. The post-test cellar was drilled on or about May 15, 1989. Figure 2-7 is a photograph of the mud spill at this CAS.

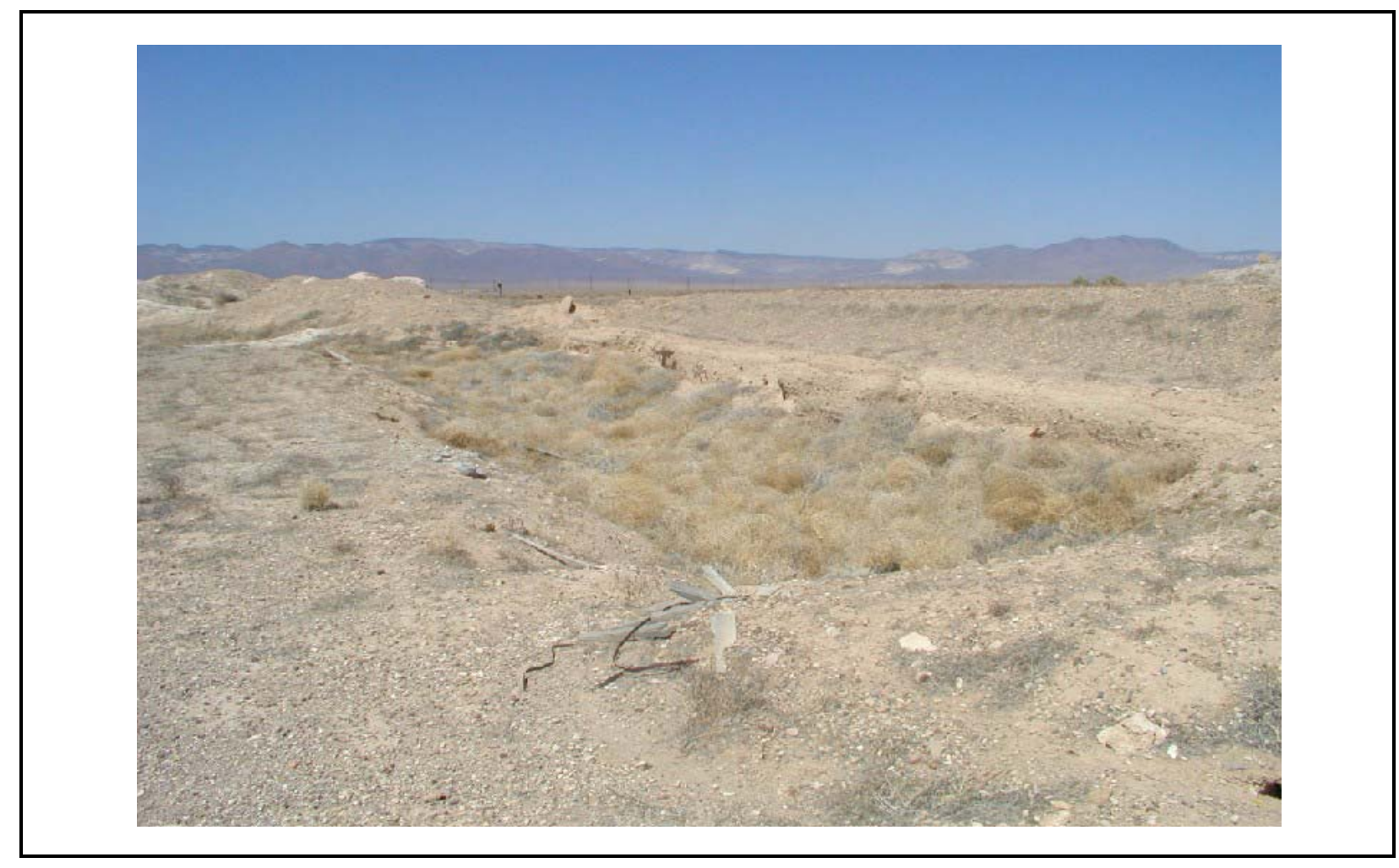

Figure 2-4

Suction Pit in Northern Footprint, CAS 03-09-02, Mud Dump Trenches 


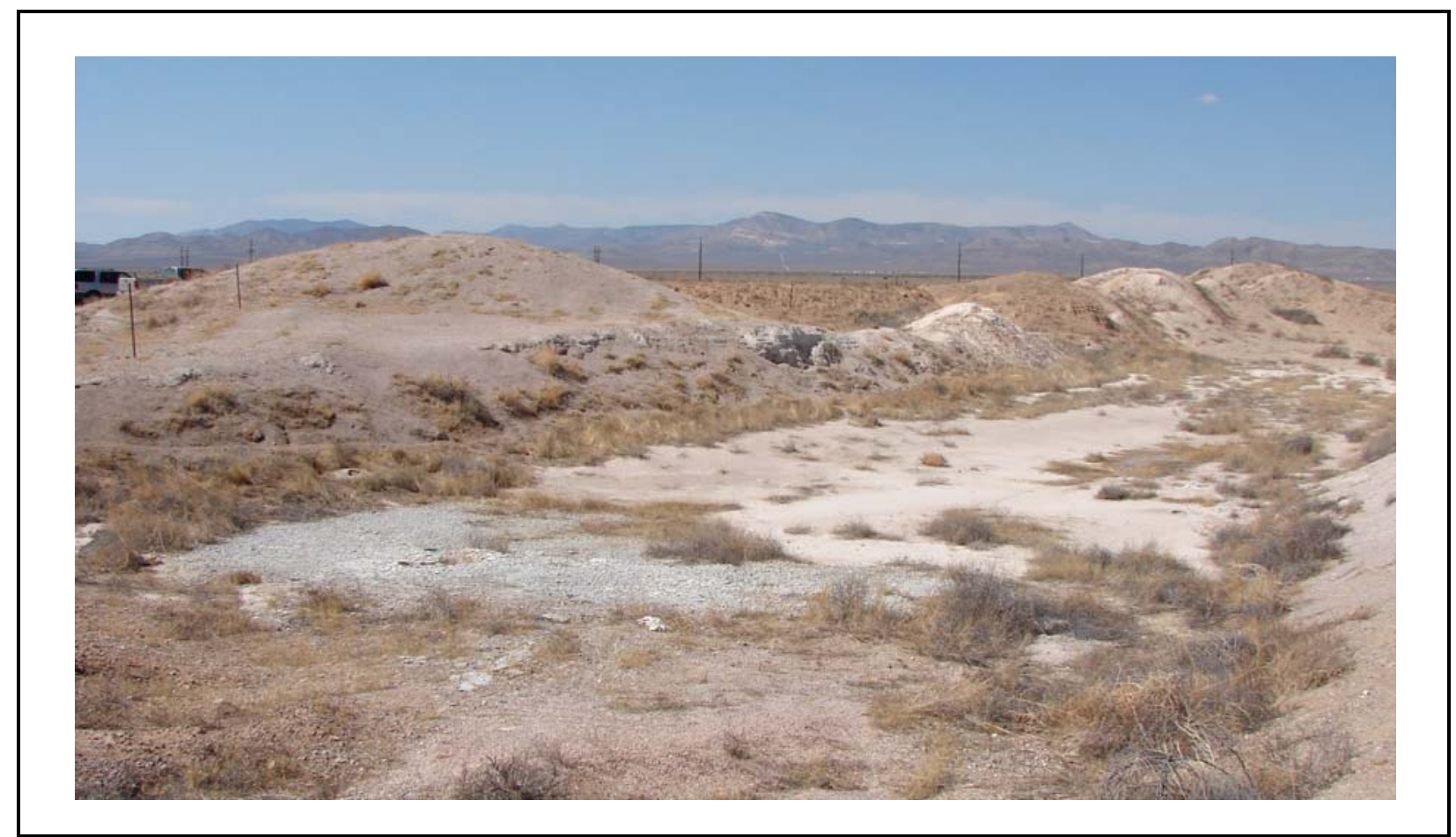

Figure 2-5

Mud Pit in Northern Footprint, CAS 03-09-02, Mud Dump Trenches

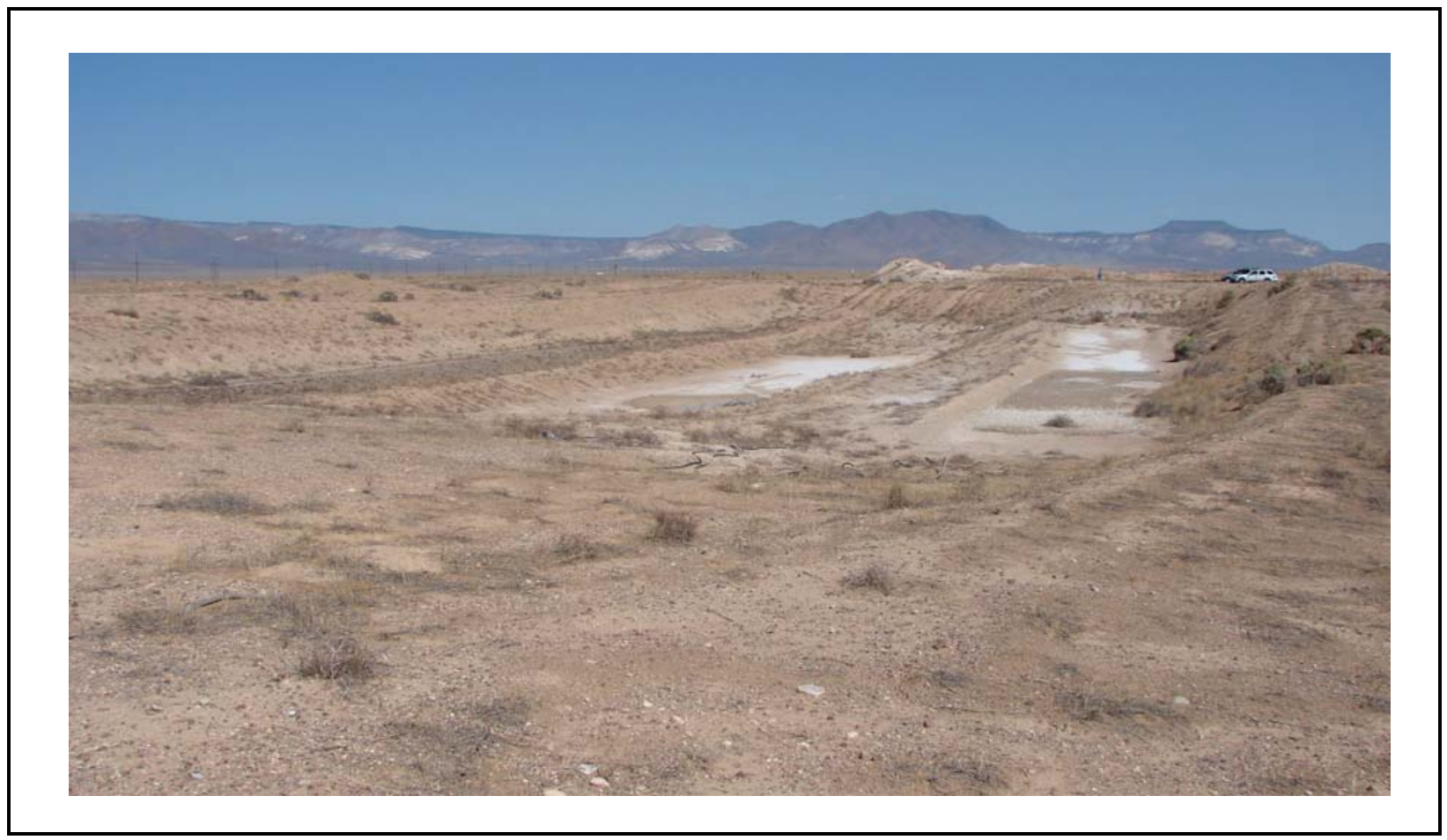

Figure 2-6

Mud Pits in Southern Footprint, CAS 03-09-02, Mud Dump Trenches 


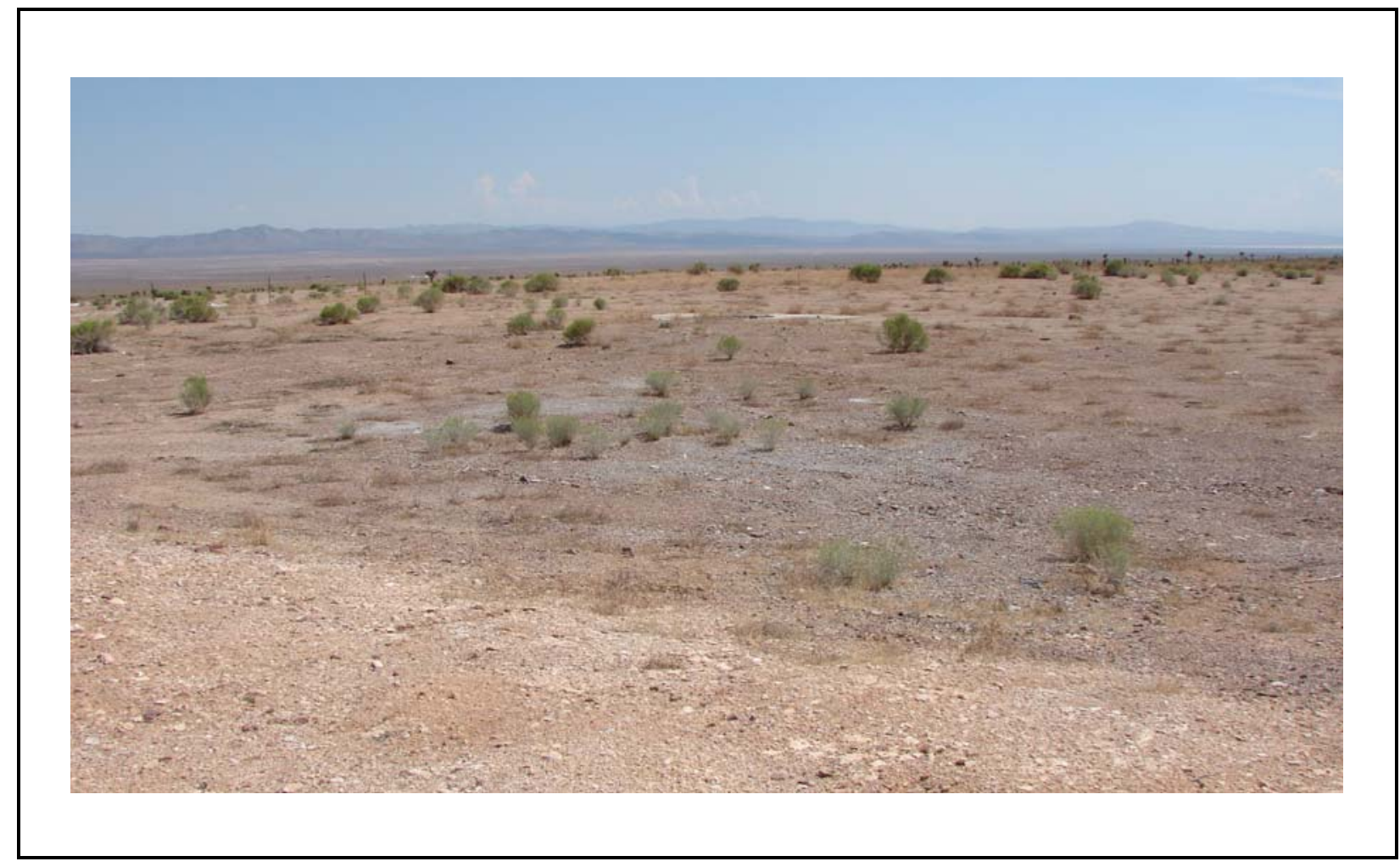

Figure 2-7

Corrective Action Site 04-44-02

\subsubsection{Corrective Action Site 04-99-02, Mud Spill}

Corrective Action Site 04-99-02 consists of a grouping of five drilling mud spills (designated "Spill Site A" through "Spill Site E”) associated with the drilling of the U-4at emplacement hole. The crater formed by the test within the U-4at emplacement hole is fenced and posted, and the associated mud spills are located within, partially within, and outside the fenced crater area. The CAS is the potential release of contaminants from the spilled drilling muds to the surrounding soils. Figure 2-8 is a photograph of Spill Site C at this CAS.

\subsubsection{Corrective Action Site 12-09-01, Mud Pit}

The CAS 12-09-01 mud pit was formed in early 1969 during the drilling of the U12r PS \#1A post-test cellar. Figure 2-9 is a photograph of the mud pit. Figure 2-10 shows a pipe and cylindrical metal debris that were left at the site and located within individual footprints separate from that of the mud pit. It is unknown exactly when the pipe and cylindrical metal debris were placed at the site, but an aerial photograph taken circa 1969 identifies the presence of the debris. 


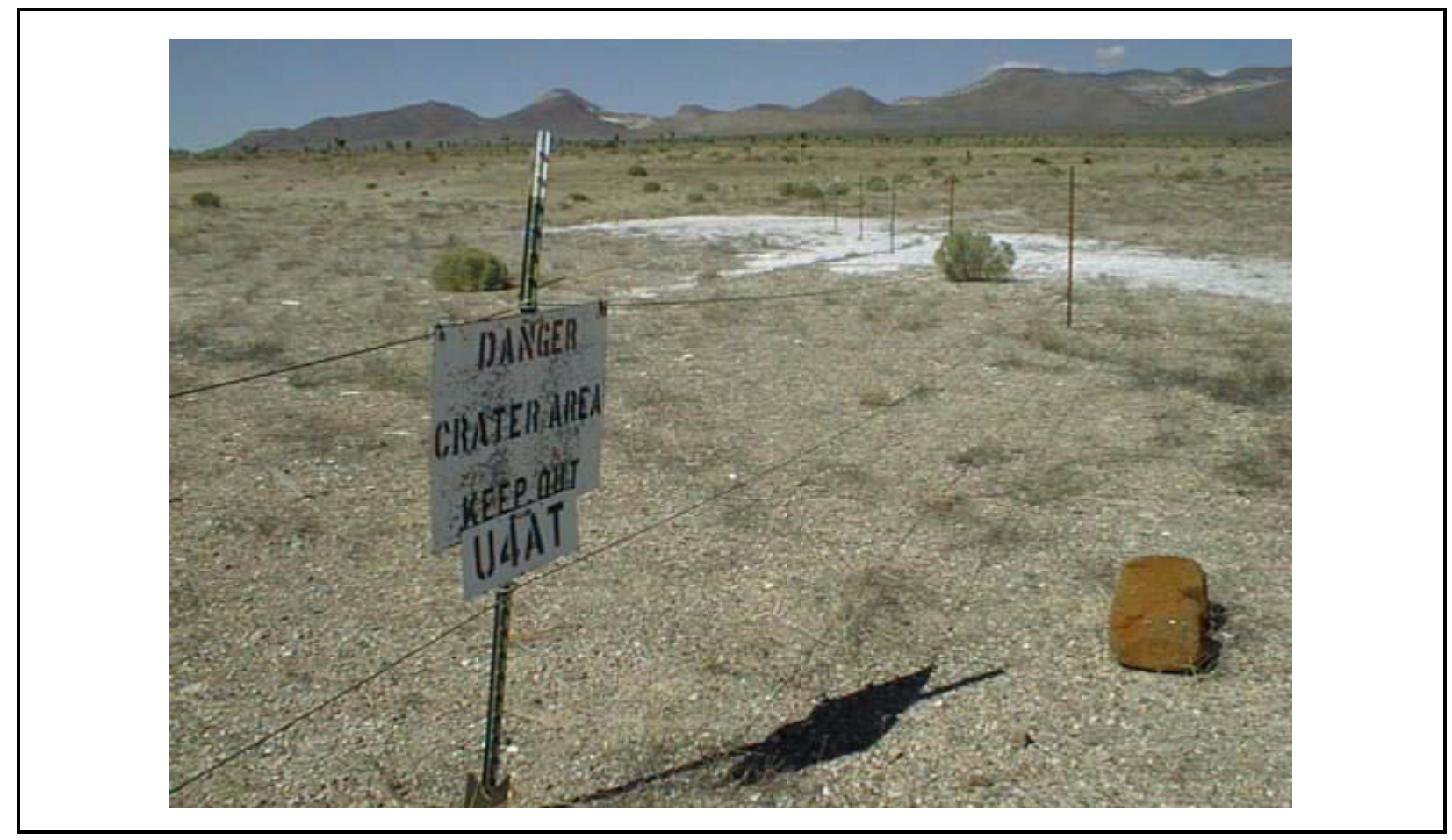

Figure 2-8

Spill Site C at Corrective Action Site 04-99-02

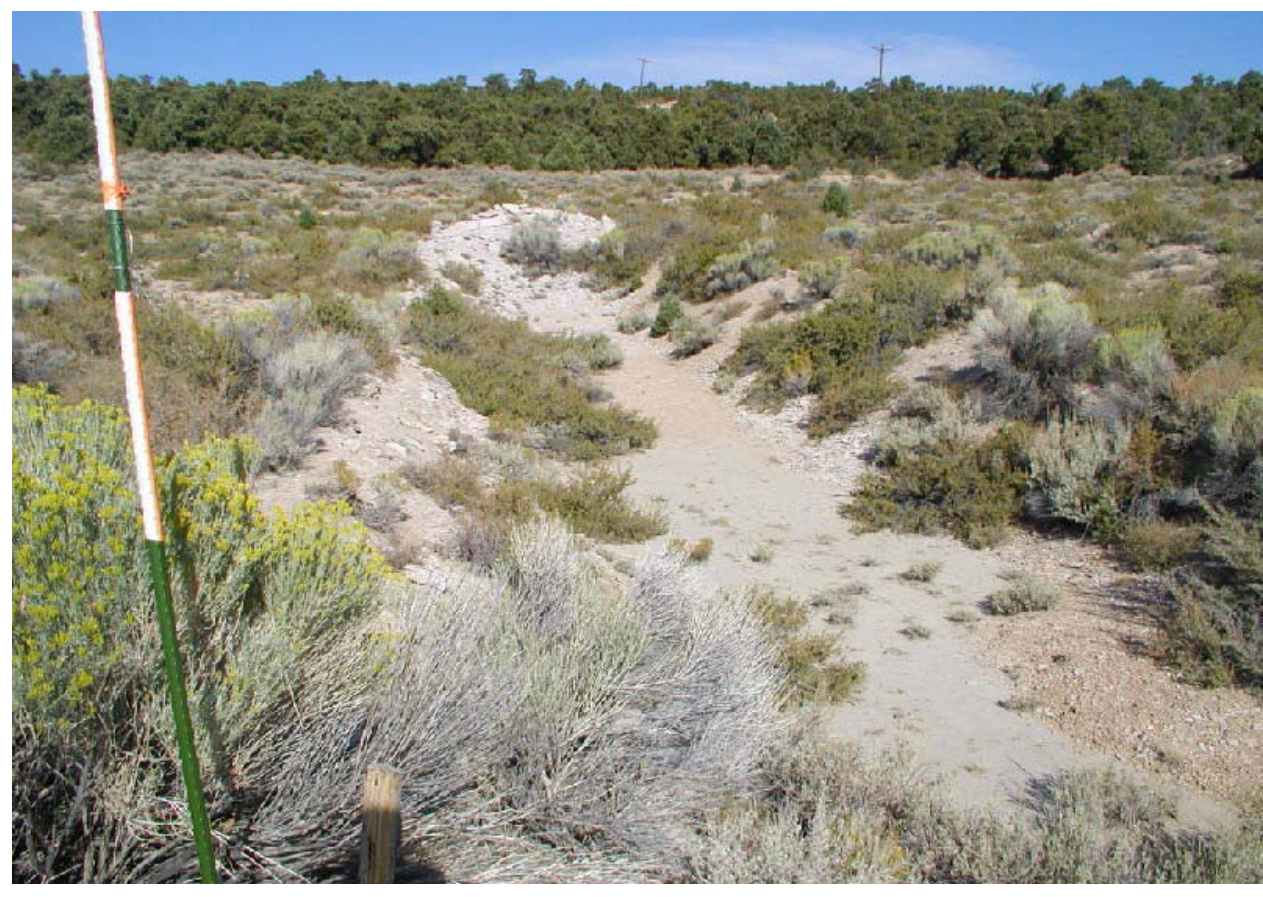

Figure 2-9

Mud Pit at Corrective Action Site 12-09-01 


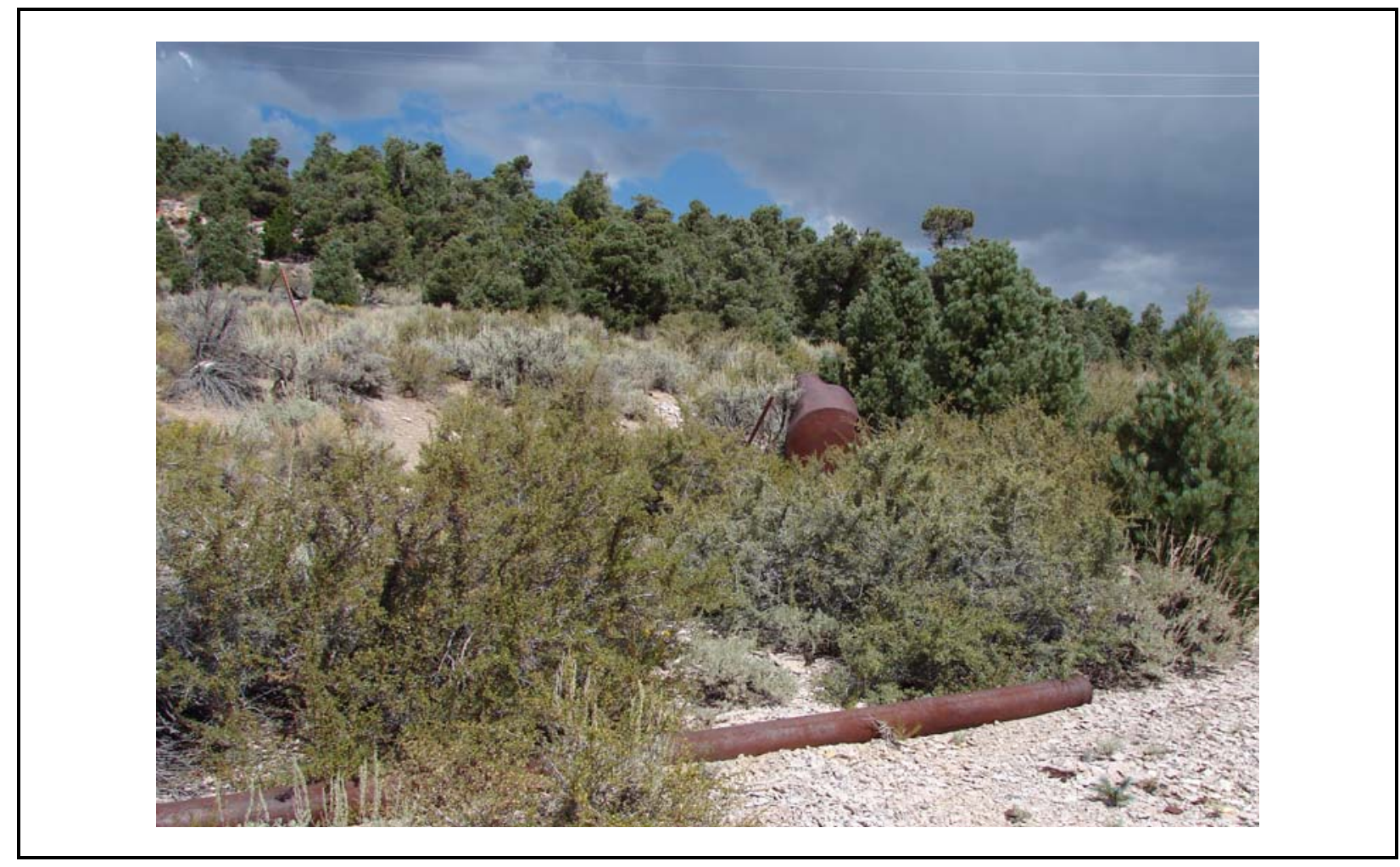

Figure 2-10

Debris at CAS 12-09-01, Mud Pit

\subsubsection{Corrective Action Site 12-09-04, Mud Pit}

The mud pit consists of a natural drainage channel that was used for the disposal of drilling muds during the construction of the U-12r emplacement hole. Drilling of the emplacement hole occurred between March 23 and October 24, 1962. The Wineskin test in emplacement hole U-12r created a crater that changed the slope of a portion of the drainage channel containing the drilling mud so that it sloped back towards the emplacement hole. The CAS is partially within the fenced crater subsidence area. Figure 2-11 is a photograph of a portion of the mud pit outside the fenced crater subsidence area.

\subsubsection{Corrective Action Site 12-09-08, Mud Pit}

Corrective Action Site 12-09-08 mud pit is associated with the drilling of U12e.14 HFR CH\#1 that began on November 9, 1972. The exact date of the mud pit construction is unknown. The U12e.14 test (Dido Queen) took place on June 5, 1973, and activity at the site ended shortly thereafter. Figure 2-12 shows the debris (pipe and crushed drums) left at this CAS. 


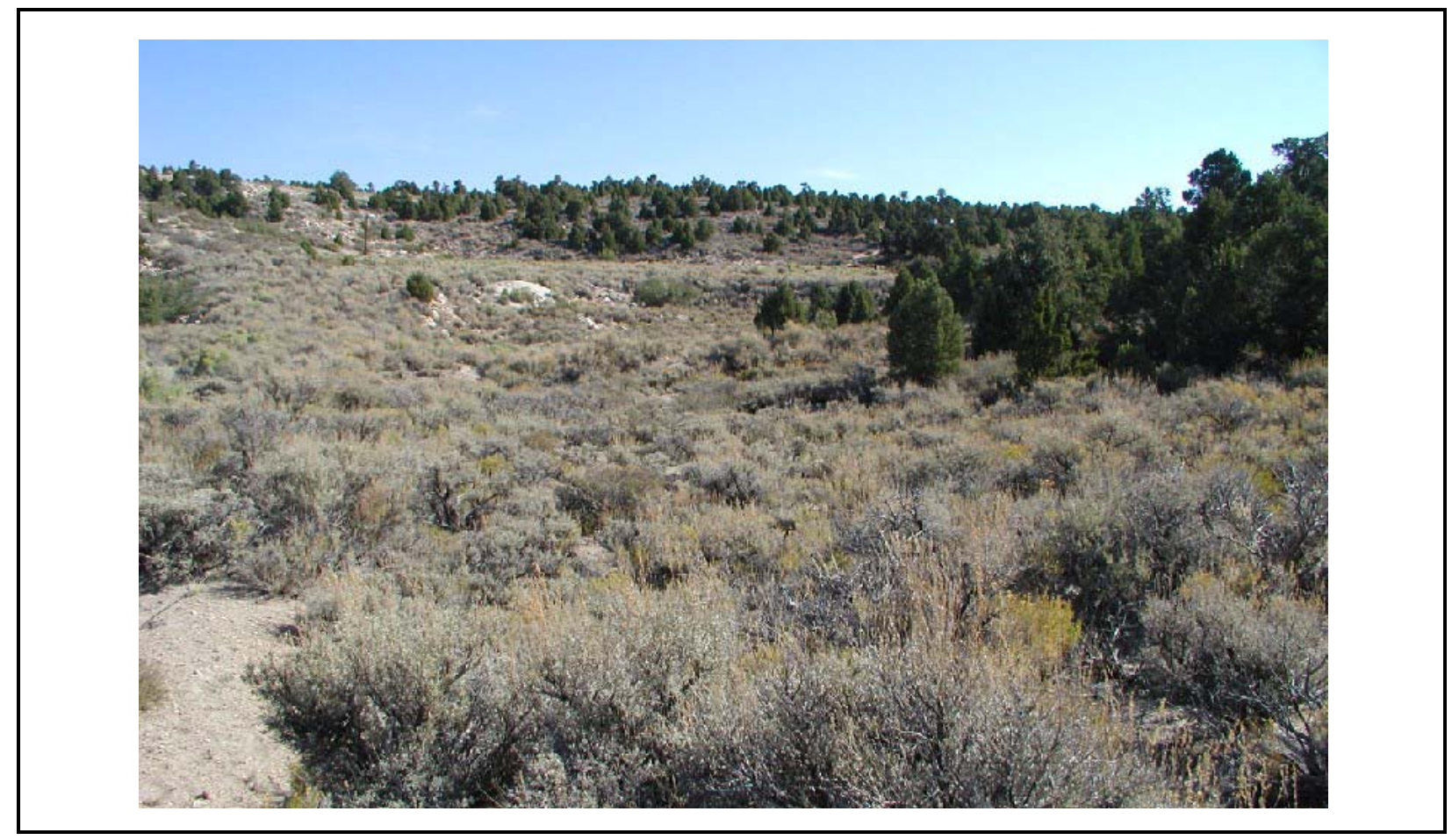

Figure 2-11

Mud Pit with Crater in Background at CAS 12-09-04, Mud Pit

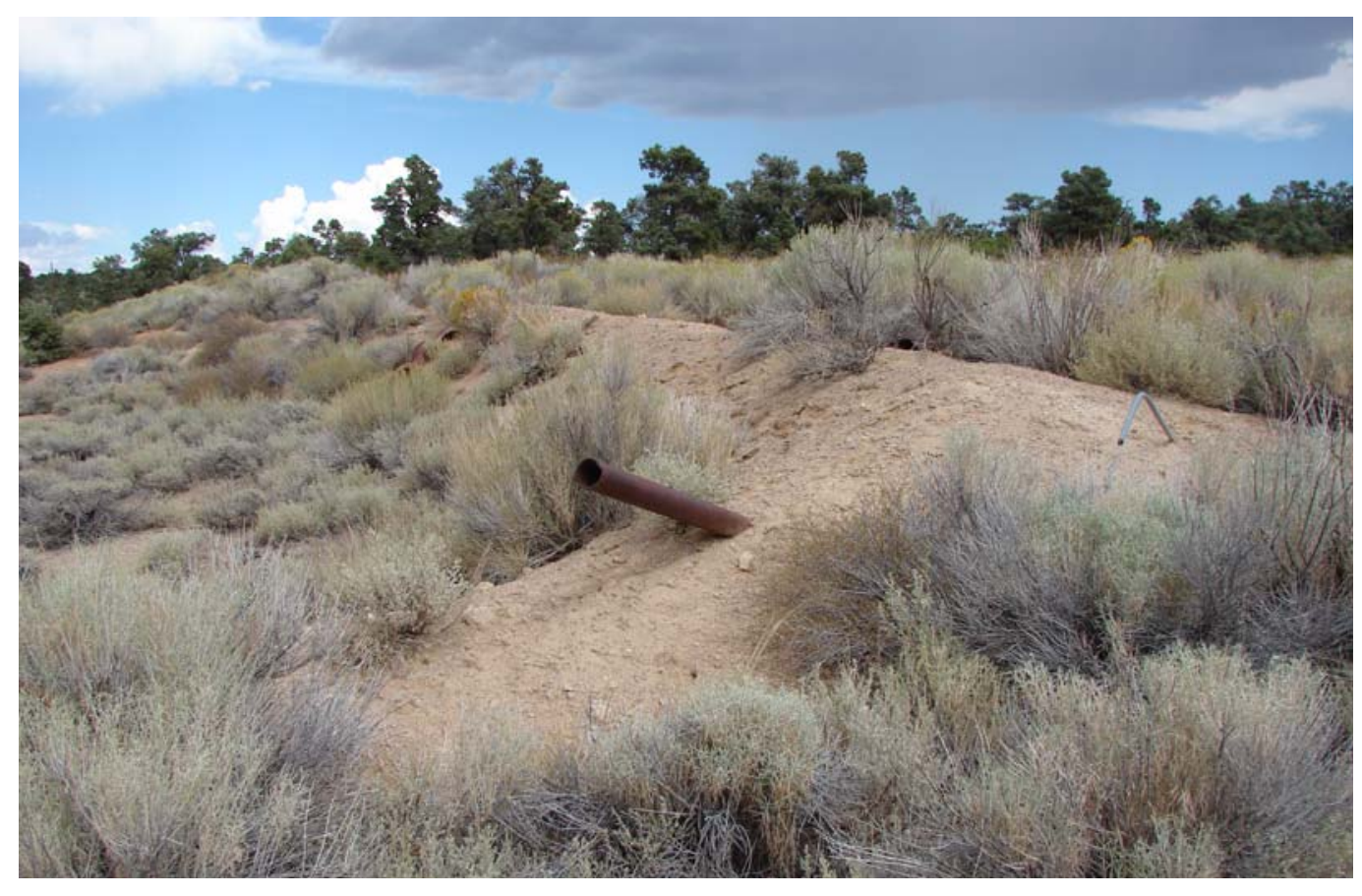

Figure 2-12

Pipe and Crushed Drums at CAS 12-09-08, Mud Pit 


\subsubsection{Corrective Action Site 12-30-14, Cellar}

The CAS 12-30-14 cellar was the site for the drilling of the U12r PS\#1A and U12r PS\#1AS post-test boreholes. U12r PS\#1A (2,045 ft bgs) was drilled from January 19 to 23, 1969, and U12r PS\#1AS (2,007 ft bgs) was drilled from January 23 to 24, 1969. The Wineskin test took place in U12r on January 15, 1969. The cellar is $9 \mathrm{ft}$ deep and $10 \mathrm{ft}$ in diameter, and is lined vertically by corrugated steel. Because of the presence of approximately $5 \mathrm{ft}$ of liquid within the cellar, it is unknown what the construction of the cellar floor might be. These post-test boreholes are currently under consideration for future use as monitoring boreholes by the Borehole Management Program. Figure 2-13 shows the cellar at this CAS.

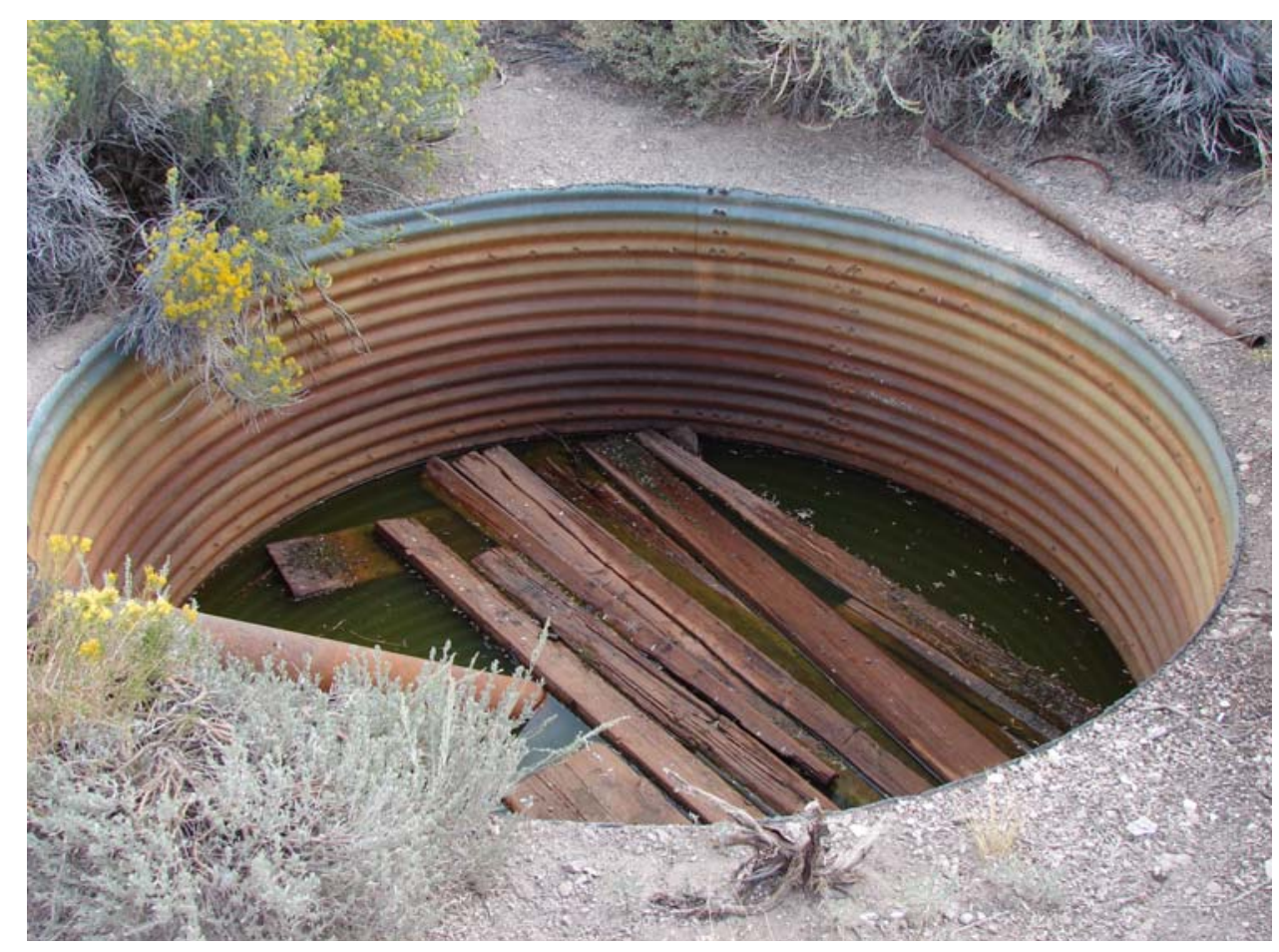

Figure 2-13

Corrective Action Site 12-30-14, Cellar 


\subsubsection{Corrective Action Site 12-99-07, Mud Dump}

Corrective Action Site 12-99-07 is located at the south end of the Area 12 Batch Plant and consists of an area of dumped concrete from vehicles that transported concrete from the plant to various NTS locations. The area of concrete is approximately 200 by $200 \mathrm{ft}$. The Batch Plant was constructed between 1972 and 1974, and in approximately 1998, its use was discontinued. Figure 2-14 is a photograph of the concrete dumped at this CAS.

\subsubsection{Corrective Action Site 15-09-01, Mud Pit}

Corrective Action Site 15-09-01 is a mud spill that resulted from drilling mud that flowed gravitationally to a berm where it accumulated into its current triangular shape. The mud was used in the drilling of instrument hole U-15GZ \#14 that was drilled between September 8, 1964, and March 3, 1965. Figure 2-15 is a photograph of this CAS.

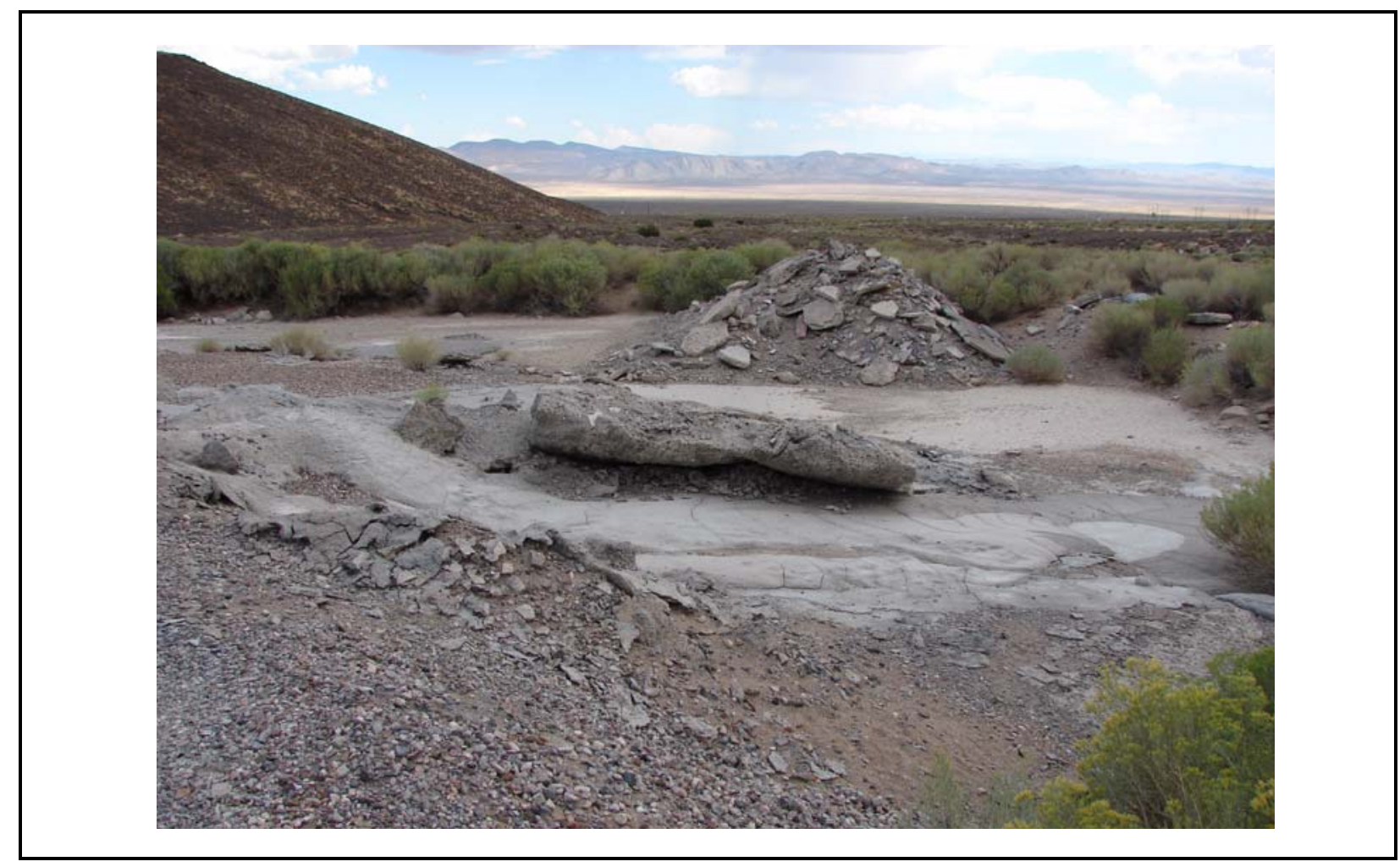

Figure 2-14

Corrective Action Site 12-99-07, Mud Dump 


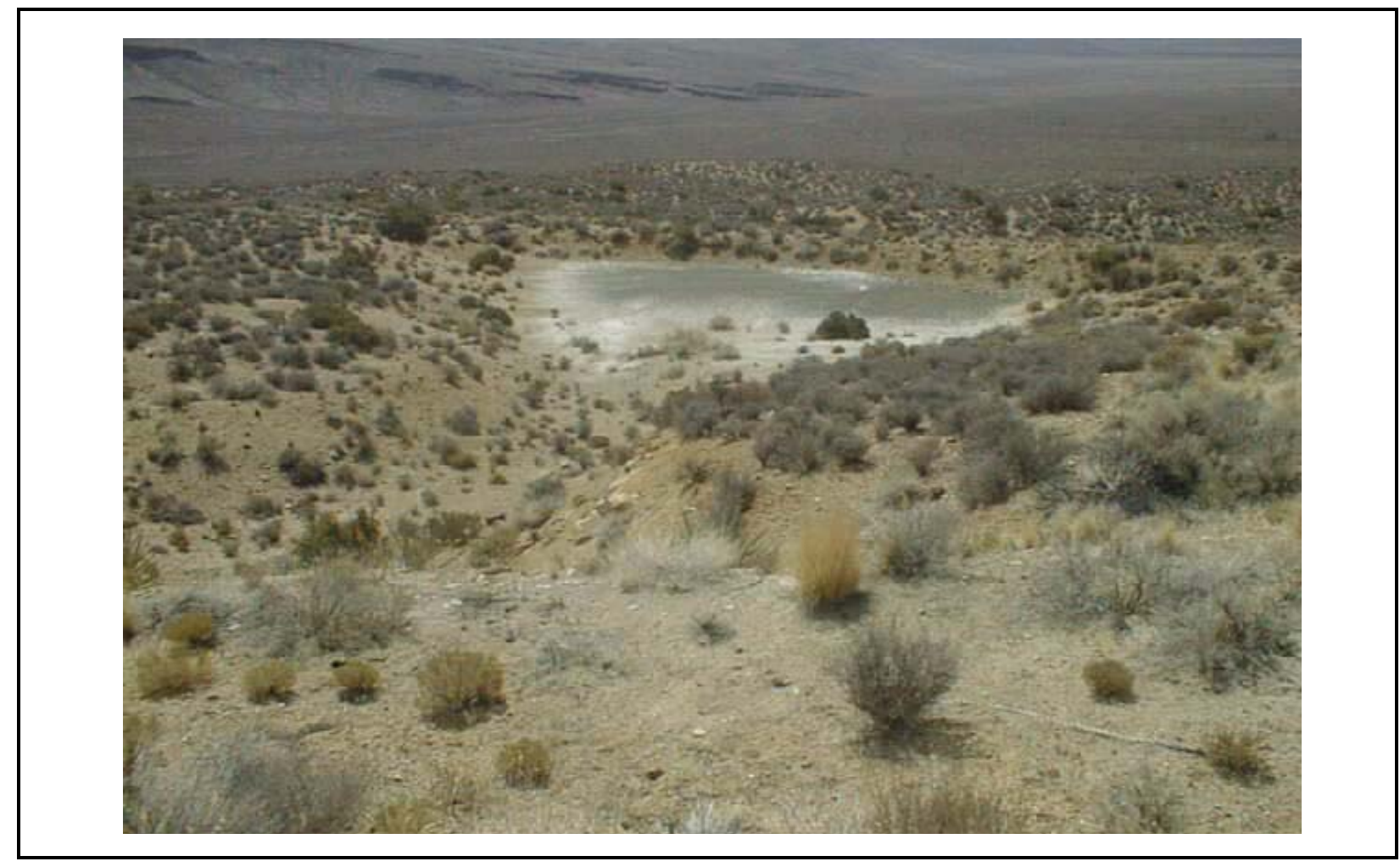

Figure 2-15

Corrective Action Site 15-09-01, Mud Pit

\subsection{Waste Inventory}

Available documentation, interviews with former site employees, process knowledge, and general historical NTS practices were used to identify wastes that may be present. Historical information and site visits indicate that the sites contain wastes such as construction materials and debris, equipment parts, and other miscellaneous debris.

\subsubsection{Corrective Action Site 02-09-48, Area 2 Mud Plant \#1}

Solid waste items identified at CAS 02-49-08 include the drilling mud and a 55-gallon (gal) drum laying on its side within the mud sump. The drilling mud is expected to be sanitary based on previous investigations described in Section 2.5. As the contents of the drum are unknown, the potential waste types include sanitary waste, hydrocarbon waste, Resource Conservation and Recovery Act (RCRA) hazardous waste, radioactive waste, and mixed waste. 


\subsubsection{Corrective Action Site 02-09-49, Area 2 Mud Plant \#2}

Solid waste items identified at CAS 02-09-49 consist of unused drilling muds. The drilling mud is expected to be sanitary based on previous investigations described in Section 2.5.

\subsubsection{Corrective Action Site 02-99-05, Mud Spill}

Solid waste items identified at CAS 02-99-05 consist of concrete left from the legacy cementing of post-test cellar U-2bp-2 PS \#1A. The cement is expected to be sanitary based on previous investigations described in Section 2.5 .

\subsubsection{Corrective Action Site 03-09-02, Mud Dump Trenches}

Solid waste items identified at CAS 03-09-02 include drilling mud and a piece of pipe of unknown length beneath the tumbleweeds within the suction pit. The pipe is not connected to a system and appears to have been discarded in the suction pit. Various small pieces of construction debris may also lie beneath the dense accumulation of tumbleweeds within the suction pit. The drilling mud is expected to contain radionuclides based on process knowledge. If no radionuclides are identified in the drilling mud, then it will be treated as sanitary. As the contents of the pipe are unknown, potential waste types include sanitary waste, hydrocarbon waste, RCRA hazardous waste, radioactive waste, and mixed waste.

\subsubsection{Corrective Action Site 04-44-02, Mud Spill}

Solid waste items identified at CAS 04-44-02 consist of spilled drilling mud. The drilling mud is expected to be sanitary based on previous investigations described in Section 2.5.

\subsubsection{Corrective Action Site 04-99-02, Mud Spill}

Solid waste items identified at CAS 04-99-02 consist of spilled drilling muds. The drilling mud is expected to be sanitary based on previous investigations described in Section 2.5.

\subsubsection{Corrective Action Site 12-09-01, Mud Pit}

Solid waste items identified at CAS 12-09-01 include drilling mud, a piece of pipe, and a large cylindrical-shaped piece of metal debris. The pipe is not connected to a system and is entirely 
exposed on the soil surface. The cylindrical-shaped piece of metal debris is resting on its side, with a metal grating attached to one end, and an opening that at one time was covered by a hinged, metal door. Debris inside the hole where the door was located includes rusted cans, glass, and other small items. Because the source of the pipe and cylindrical metal debris is unknown, potential waste types include sanitary waste, hydrocarbon waste, RCRA hazardous waste, radioactive waste, and mixed waste. All waste types may be comprised of debris, IDW, decontamination liquids, and soils.

\subsubsection{Corrective Action Site 12-09-04, Mud Pit}

Solid waste items identified at CAS 12-09-04 consist of drilling mud placed in a natural depression and allowed to flow away from the U-12r emplacement hole drilling area. The mud flowed in a northeast direction to a maximum of approximately $170 \mathrm{ft}$. The mud is surrounded on the east side by a small hill, on the west side by a low berm, and on the north by a mound. The mud did not travel north beyond this mound. The mud pit trends from northeast to southwest. The southwest reach of the mud pit is approximately $450 \mathrm{ft}$ to the south-southwest of the $\mathrm{U}-12 \mathrm{r}$ borehole. The drilling mud is expected to be sanitary based on previous investigations described in Section 2.5.

\subsubsection{Corrective Action Site 12-09-08, Mud Pit}

Solid waste items identified at CAS 12-09-08 include a section of pipe protruding from the mud pit berm wall, a pile of crushed drums, and various small pieces of construction debris. The angle of the pipe protruding from the berm wall suggests it is not connected to any system, and the depth that it extends below ground surface is unknown. As the source of the pipe and crushed drums is unknown, potential waste types include sanitary waste, hydrocarbon waste, RCRA hazardous waste, radioactive waste, and mixed waste. All waste types may be comprised of debris, IDW, decontamination liquids, and soils.

\subsubsection{Corrective Action Site 12-30-14, Cellar}

Solid waste items identified at CAS 12-30-14 include several pieces of dimensional lumber both inside and outside the cellar. A section of metal pipe is standing inside the cellar and protrudes several feet above ground surface. Additional debris may also be located on the floor of the cellar, but because of the presence of approximately $5 \mathrm{ft}$ of liquid, the floor of the cellar cannot be seen. As the source of the liquid and sediment is unknown, potential waste types include sanitary waste, 
hydrocarbon waste, RCRA hazardous waste, radioactive waste, and mixed waste. All waste types may be comprised of debris, liquids, IDW, decontamination liquids, and soils.

\subsubsection{Corrective Action Site 12-99-07, Mud Dump}

Solid waste items identified at CAS 12-99-07 consist of cement left from dumping cement from vehicles used to transport cement to operations on the NTS. The cement is expected to be sanitary based on previous investigations described in Section 2.5.

\subsubsection{Corrective Action Site 15-09-01, Mud Pit}

Solid waste items identified at CAS 15-09-01 consist of spilled drilling mud. Although listed as a mud pit, the drilling mud was placed into a low-lying area near the U-15GZ \#14 drill site and allowed to flow a short distance (approximately $180 \mathrm{ft}$ ) downgradient, where its progress was stopped by a natural berm. The drilling mud collected in a triangular-shaped pattern, measuring approximately 70 by $100 \mathrm{ft}$ at the extremes. The drilling mud is expected to be sanitary based on previous investigations described in Section 2.5.

\subsection{Release Information}

Known or suspected releases from the CASs, including potential release mechanisms, and migration routes associated with each of the CASs that will undergo investigation are described in the following subsections. There has been no known migration of contamination beyond a shallow layer of surface soil at any of the CAU 234 CASs. Potentially affected media for all CASs include surface and shallow subsurface soil. Exposure routes to site workers include ingestion, inhalation, and/or dermal contact (absorption) from disturbance of contaminated soils, debris, and/or structures. Site workers may also be exposed to radiation by performing activities in proximity to radiologically contaminated materials.

The following subsections contain CAS-specific descriptions of known or suspected releases associated with CAU 234. 


\subsubsection{Corrective Action Site 02-09-48, Area 2 Mud Plant \#1}

There is no potential for release of contaminants associated with the unused drilling mud located within the concrete-lined mud sump. Because it is believed that the mud in the mud storage sump is unused, there is no reason to believe that the mud contains potential contaminants. The presence of the rusted metal drum within the mud pit poses a potential for release of contaminants to the mud storage sump.

Contaminants may have leaked from the 55-gal drum subsequent to its placement in the mud sump. If a release occurred, contaminants would have been limited in volume and are expected to be located in the soil in close proximity to the drum.

\subsubsection{Corrective Action Site 02-09-49, Area 2 Mud Plant \#2}

There is no potential for release of contaminants associated with the drilling mud contained within the concrete-lined former water reservoir, because the mud is believed to be unused and therefore does not contain potential contaminants. No potential releases have been identified at this CAS.

\subsubsection{Corrective Action Site 02-99-05, Mud Spill}

There is no potential for release of contaminants associated with the cement pile left from the legacy grouting operation at post-test cellar U-2bp-2 PS \#1A. No potential releases have been identified at this CAS.

\subsubsection{Corrective Action Site 03-09-02, Mud Dump Trenches}

Potential release of contaminants is associated with the drilling muds associated with the mud, suction, and reserve pits associated with emplacement hole U-3kz. Contaminants may have been brought to the surface from drilling operations that intercepted a radiation contaminant plume from another test nearby. The drilling muds were being used for an emplacement hole and were not expected to encounter any contamination that would be brought to the surface during the drilling operation. Radiation was detected after drilling mud had been brought to the surface and disposed of in the mud pits. Contamination, if present, is expected to have remained within the bermed walls of the mud pits, with minimal vertical migration due to the binding properties of the drilling muds. 
Additional potential release of contaminants is associated with the discarded section of pipe found within the suction pit. No other potential releases are associated with this CAS.

\subsubsection{Corrective Action Site 04-44-02, Mud Spill}

There is no potential for release of contaminants associated with the spilled drilling mud used for the drilling of the U-4at PS \#1A post-test cellar. No potential releases have been identified at this CAS.

\subsubsection{Corrective Action Site 04-99-02, Mud Spill}

There is no potential for release of contaminants associated with the spilled drilling muds used for the drilling of the U-4at emplacement hole. No potential releases have been identified at this CAS.

\subsubsection{Corrective Action Site 12-09-01, Mud Pit}

Potential release of contaminants are associated with the section of metal pipe, and large metal cylindrical-shaped debris, that are each associated with their own footprint. Contaminants may have originated from the pipe and/or from the large cylindrical-shaped metal debris subsequent to placement at their current locations. If a release occurred, contaminants would have been limited in volume and are expected to be located in the soil within close proximity to the pipe and/or cylindrical-shaped debris. There is no potential for release associated with the drilling mud within the mud pit.

\subsubsection{Corrective Action Site 12-09-04, Mud Pit}

There is no potential for release of contaminants associated with the mud used during the emplacement hole drilling. No potential releases have been identified at this CAS.

\subsubsection{Corrective Action Site 12-09-08, Mud Pit}

Potential release of contaminants are associated with the partially buried pipe and crushed drums within the mud pit. If a release occurred from the pipe or crushed drums, contaminants would have been limited in volume and are expected to be located in the soil within close proximity to pipe and the drums. There is no potential for release associated with the drilling mud within the mud pit. 


\subsubsection{Corrective Action Site 12-30-14, Cellar}

Potential release of contaminants is associated with the sediments and liquid contained in the U-12r PS\#1A post-test cellar. No other potential releases have been identified at this CAS.

\subsubsection{Corrective Action Site 12-99-07, Mud Dump}

There is no potential for release of contaminants associated with the concrete dumped from delivery vehicles at this CAS. No potential releases have been identified at this CAS.

\subsubsection{Corrective Action Site 15-09-01, Mud Pit}

There is no potential for release of contaminants associated with drilling muds used in the construction of instrument hole U-15GZ \#14. No potential releases have been identified at this CAS.

\subsection{Investigative Background}

The CAU 234 mud pit and mud spill CASs are very similar to the CASs investigated in the Closure Report (CR) for Corrective Action Units 530, 531, 532, 533, 534, 535: NTS Mud Pits (NNSA/NSO, 2006a). The Mud Pit CR demonstrated that total petroleum hydrocarbons (TPH)-diesel-range organics (DRO) is not a COC at NTS mud pit CASs (no other COPCs were identified in the Mud Pit $\mathrm{CR}$ and provided the following recommendation:

"Therefore, consistent with the conclusions and recommendations in the Mud Pit CR and SAFER Plan, non-radioactive mud pit CASs identified in the future should be transferred directly from Appendix II to Appendix IV of the FFACO, provided they meet the following criteria:

- The CAS is either a single mud pit or a system of mud pits.

- The CAS is not located in a radiological or radioactive material posted area.

- The CAS does not serve as habitat for threatened and endangered species.

- There are no biasing factors evident based on a visual inspection.”

The CAU 234 mud pit or mud spill CASs that meet these criteria will not require additional sample collection. Also, CASs that only contain unused drilling mud or concrete will not require sampling, because there are no identified potential releases of hazardous waste associated with unused drilling 
mud or concrete. As an aid in the identification of which CAU 234 CASs do not require additional sample collection, the CASs have been divided into three categories as follows:

- Category I CASs are those in which the mud pits or mud spills fit the Mud Pit CR criteria and will be recommended for closure with no further investigation.

- Category II CASs are those in which the mud pits or mud spills are comprised only of unused drilling mud or concrete where there are no indicators of a potential to release. These CASs do not fit the Mud Pit CR criteria, because unused drilling muds were not included in the investigation. However, as the drilling muds were not used for field operations, they possess no potential for release of contaminants.

- Category III CASs do not meet the criteria of the Mud Pit CR, because they contain a potential release that was not addressed by the Mud Pit CR.

Each CAS will be classified by Category I, II, or III according to Table 2-1. Only Category III CASs will require that additional samples be collected. Therefore, DQOs will be developed only for those CASs. Justification for not sampling each CAS assigned to Category I or II is provided in Section 2.6.

Table 2-1

Corrective Action Site Categorization for CAU 234

\begin{tabular}{|c|c|c|c|}
\cline { 2 - 4 } \multicolumn{1}{c|}{} & \multicolumn{3}{c|}{ CAS Category } \\
\cline { 2 - 4 } & I & II \\
\hline \multirow{2}{*}{ CAS Number } & $\begin{array}{c}04-44-02,04-99-02, \\
12-09-04,15-09-01\end{array}$ & $\begin{array}{c}02-09-49,02-99-05, \\
12-99-07\end{array}$ & $\begin{array}{c}02-09-48,03-09-02,09-01,12-09-08, \\
12-30-14\end{array}$ \\
\hline
\end{tabular}

The following subsections summarize the investigations conducted at the CAU 234 sites. More detailed discussions of these investigations are in Appendix A.

\subsubsection{Corrective Action Site 02-09-48, Area 2 Mud Plant \#1}

No samples have been collected for analysis from this CAS. There is no record of a geophysical survey for this CAS. 
On May 23, 2006, a radiological survey was performed of the mud sump and the former water reservoir (not a part of this CAS). The findings of the survey were not significantly different than background (SNJV, 2006).

\subsubsection{Corrective Action Site 02-09-49, Area 2 Mud Plant \#2}

No samples have been collected for analysis from this CAS. A radiological walkover survey of CAS 02-09-49 conducted in 2003 identified a maximum gamma emission radiation that was not significantly different from background. In 2006, an informal geophysical survey was conducted around the reservoir to identify the direction and possible association of the extensive piping that exists at the reservoir. The results of the survey only identified piping from WW-2 to the reservoir.

On May 23, 2006, a radiological survey was performed of the mud sump (not a part of this CAS) and the former water reservoir. The findings of the survey were not significantly different from background (SNJV, 2006).

\subsubsection{Corrective Action Site 02-99-05, Mud Spill}

Samples were collected from the concrete and surrounding soil for analysis on August 27, 1997. The samples were analyzed for volatile organic compounds (VOCs), semivolatile organic compounds (SVOCs), radionuclides, and RCRA metals. No COCs were identified in the samples.

\subsubsection{Corrective Action Site 03-09-02, Mud Dump Trenches}

No samples have been collected for analysis from this CAS. There is no record of a geophysical or radiological survey for this CAS.

\subsubsection{Corrective Action Site 04-44-02, Mud Spill}

No samples have been collected for analysis from this CAS. A radiological walkover survey was conducted at CAS 04-44-02 on May 15, 2006. None of the results were significantly above background levels in the walkover survey. There is no record of a geophysical survey for this CAS. 


\subsubsection{Corrective Action Site 04-99-02, Mud Spill}

No samples have been collected for analysis from this CAS. A radiological walkover survey was conducted at CAS 04-99-02 on May 15, 2006. Radiation emission results were not significantly different from background levels. There is no record of a geophysical or survey for this CAS.

\subsubsection{Corrective Action Site 12-09-01, Mud Pit}

No samples have been collected for analysis from this CAS. No record of a geophysical survey has been identified. No radiological survey has been performed for this CAS.

\subsubsection{Corrective Action Site 12-09-04, Mud Pit}

There is no record of sampling or geophysical work performed at this CAS. No radiological survey has been performed for this CAS.

\subsubsection{Corrective Action Site 12-09-08, Mud Pit}

No samples have been collected for analysis from this CAS. No record of a geophysical survey has been identified. No radiological survey has been performed for this CAS.

\subsubsection{Corrective Action Site 12-30-14, Cellar}

No samples have been collected for analysis from this CAS. No record of a geophysical survey has been identified. No radiological survey has been performed for this CAS.

\subsubsection{Corrective Action Site 12-99-07, Mud Dump}

No samples have been collected for analysis from this CAS. The CAS consists of an area of concrete dumped from vehicles used for carrying concrete to various projects within the NTS.

\subsubsection{Corrective Action Site 15-09-01, Mud Pit}

Analytical results from samples collected in August 1997 and analyzed for VOCs, SVOCs, RCRA metals, and radionuclides. No analytes were identified above their respective action levels. No geophysical or radiological survey information has been identified. The drilling mud used at this 
location was dumped into a natural slope away from the work area, and flowed to a natural berm where it accumulated into a triangular-shaped collection of drilling mud.

\subsubsection{National Environmental Policy Act}

The Final Environmental Impact Statement for the Nevada Test Site and Off-Site Locations in the State of Nevada (DOE/NV, 1996) includes site investigation activities such as those proposed for CAU 234.

In accordance with the NNSA/NSO National Environmental Policy Act (NEPA) Compliance Program, a NEPA checklist will be completed before CAU 234 site investigation activities begin. This checklist requires NNSA/NSO project personnel to evaluate their proposed project activities against a list of potential impacts that include, but are not limited to: air quality, chemical use, waste generation, noise level, and land use. Completion of the checklist results in a determination of the appropriate level of NEPA documentation by the NNSA/NSO NEPA Compliance Officer.

\subsection{CAS Categorization}

\subsubsection{Corrective Action Site 02-09-48, Area 2 Mud Plant \#1}

Corrective Active Site 02-09-48 is a Category III CAS because of the presence of the 55-gal drum in the mud sump. The drilling mud within the sump has not been used for drilling operations and, therefore, is not exposed to the potential contaminants identified in the Mud Pit CR. The drilling mud will only be sampled in association with the potential release from the 55-gal drum.

\subsubsection{Corrective Action Site 02-09-49, Area 2 Mud Plant \#2}

Corrective Active Site 02-09-49 is a Category II CAS because the drilling mud is unused. There was no exposure to the potential contaminants of used drilling muds, and there is no other potential for release identified with this CAS.

\subsubsection{Corrective Action Site 02-99-05, Mud Spill}

Because the CAS is actually a pile of dumped cement and not drilling mud, this CAS is a Category II CAS. Therefore, sampling is not necessary, and there is no potential for release. Additionally, this 
CAS has been sampled and no contaminants were identified further supporting that no sampling is required at this CAS.

\subsubsection{Corrective Action Site 03-09-02, Mud Dump Trenches}

Corrective Action Site 03-09-02 is a Category III CAS because process knowledge indicates there is a possibility for the presence of contaminants at levels not typically associated with drilling muds (Professional Analysis, Inc., 1992). The potential for release from a pipe within the suction pit is also present, exempting this CAS from the coverage provided by the similarity to CASs sampled within the Mud Pit CR.

\subsubsection{Corrective Action Site 04-44-02, Mud Spill}

The mud spill in this CAS is similar to those identified in the Mud Pit CR as CAU 535 CASs. There are no contaminants associated with CAU 535 CASs; therefore, this CAS is a Category I CAS, and sampling is not necessary, because there is no identified potential for release.

\subsubsection{Corrective Action Site 04-99-02, Mud Spill}

The mud spills within this CAS are similar to those identified in the Mud Pit CR as CAU 535 CASs. There are no contaminants associated with CAU 535 CASs; therefore, this CAS is a Category I CAS and sampling is not necessary, because there is no identified potential for release.

\subsubsection{Corrective Action Site 12-09-01, Mud Pit}

The mud pit associated with this CAS is similar to a CAU 533-type mud pit within the Mud Pit CR and therefore possesses no potential for release of COPCs. However, the presence of a length of metal pipe and a large, metal, cylindrical-shaped piece of debris is present within the CAS in footprints separate from the mud pit. The mud pit will not be sampled because of the Mud Pit CR, but the potential for release from the pipe and cylindrical debris will require investigation. Therefore, CAS 12-09-01 is a Category III CAS. 


\subsubsection{Corrective Action Site 12-09-04, Mud Pit}

The mud pit associated with this CAS is drilling mud that was placed into a natural drainage channel and flowed some $700 \mathrm{ft}$ away from the site of placement into the channel. The drilling mud is actually a mud spill, because there is no engineered containment for its reuse or storage; therefore, the CAS is similar to a CAU 535 mud pit in the Mud Pit CR. The CAS is a Category I CAS. There is no other potential for release of contaminants identified for this CAS. No further investigation is required.

\subsubsection{Corrective Action Site 12-09-08, Mud Pit}

The mud pit associated with this CAS contains a length of metal pipe extending from one of the berm walls, and some crushed drums located along the mud/berm wall interface along another berm wall. The mud pit is a CAU 534-type as identified in the Mud Pit CR, but the presence of the potential for release from the pipe and drums makes this a Category III CAS, requiring further investigation.

\subsubsection{Corrective Action Site 12-30-14, Cellar}

There is no mud pit associated with this CAS; therefore, this CAS is a Category III CAS. The potential for release associated with the cellar contents and surrounding soils requires further investigation.

\subsubsection{Corrective Action Site 12-99-07, Mud Dump}

Because there is no drilling mud associated with this CAS, it is a Category II CAS, and requires no further investigation, because there is no potential for release of contaminants from the concrete.

\subsubsection{Corrective Action Site 15-09-01, Mud Pit}

The configuration is similar to that of a mud spill identified as CAU 535 in the Mud Pit CR. Because there is no other potential release of contaminants identified for this CAS, it is a Category I CAS. 


\subsection{Objectives}

This section presents an overview of the DQOs for CAU 234 and formulation of the CSM. Also presented is a summary listing of the contaminants reasonably suspected to be present at each CAS, the COPCs, the preliminary action levels (PALs) for the investigation, and the process used to establish FALs. Additional details and figures depicting the CSM are in Appendix A.

Note: Only Category III CASs will be discussed in this section:

- CAS 02-09-48

- CAS 03-09-02

- CAS 12-09-01

- CAS 12-09-08

- CAS 12-30-14

\subsection{Conceptual Site Model}

The CSM describes the most probable scenario for current site conditions and defines the assumptions that are the basis for identifying future land use, contaminant sources, release mechanisms, migration pathways, exposure points, and exposure routes. The CSM is also used to support appropriate sampling strategies and data collection methods. The CSM has been developed for CAU 234 using information from the physical setting, potential contaminant sources, release information, historical background information, knowledge from similar sites, and physical and chemical properties of the potentially affected media and COPCs. Figure 3-1 depicts a tabular representation of the conceptual pathways to receptors from CAU 234 sources. Figure 3-2 depicts a graphical representation of the CSM. If evidence of contamination that is not consistent with the presented CSM is identified during investigation activities, the situation will be reviewed, CSM revised, DQOs re-assessed, and a recommendation made on how best to proceed. In such cases, decision-makers listed in Section A.3.1 will be notified and given the opportunity to comment on and/or concur with the recommendation.

The following sections discuss future land use and the identification of exposure pathways (i.e., combination of source, release, migration, exposure point, and receptor exposure route) for the CAU 234. 


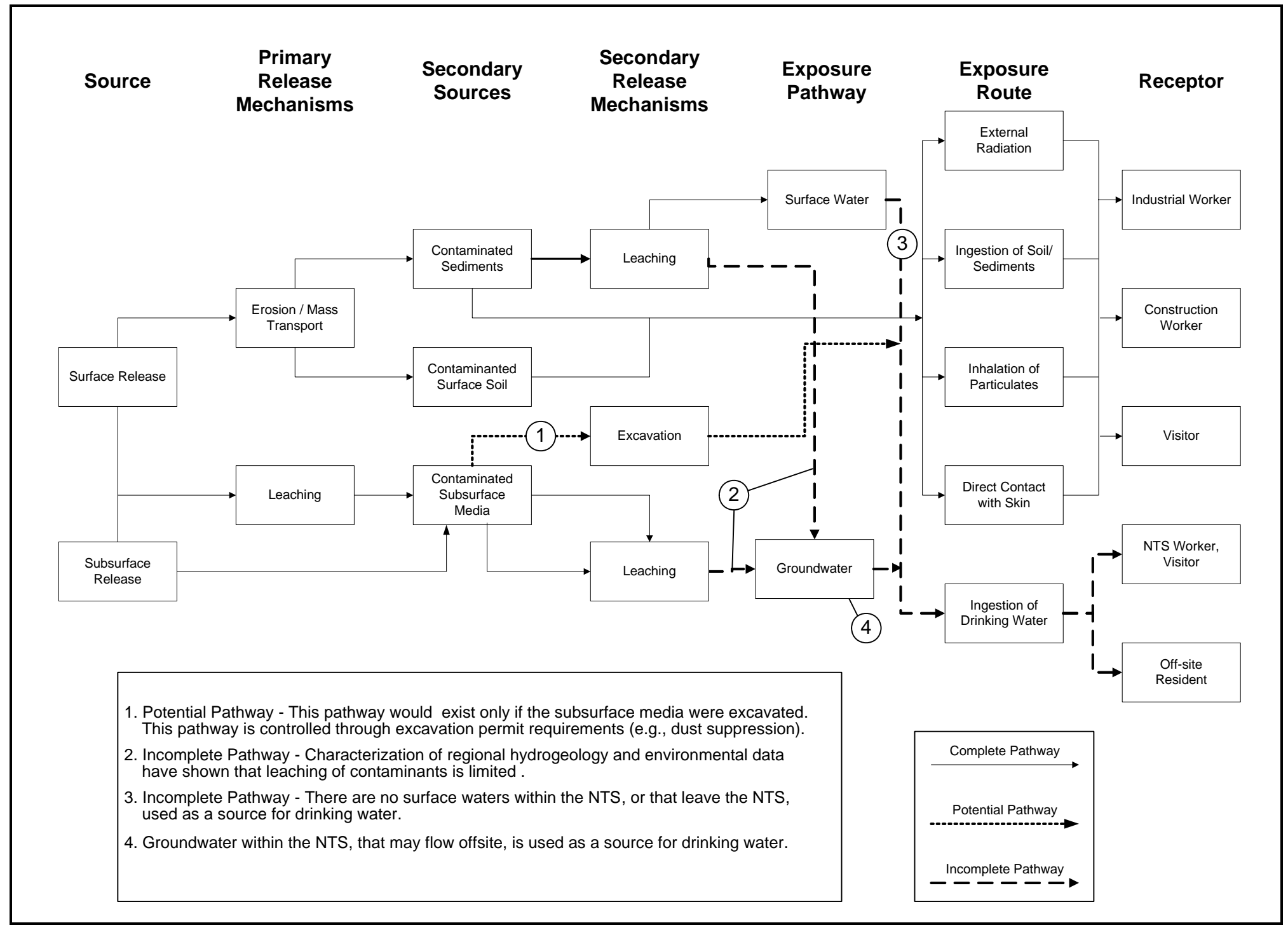

Figure 3-1

Conceptual Site Model Diagram 


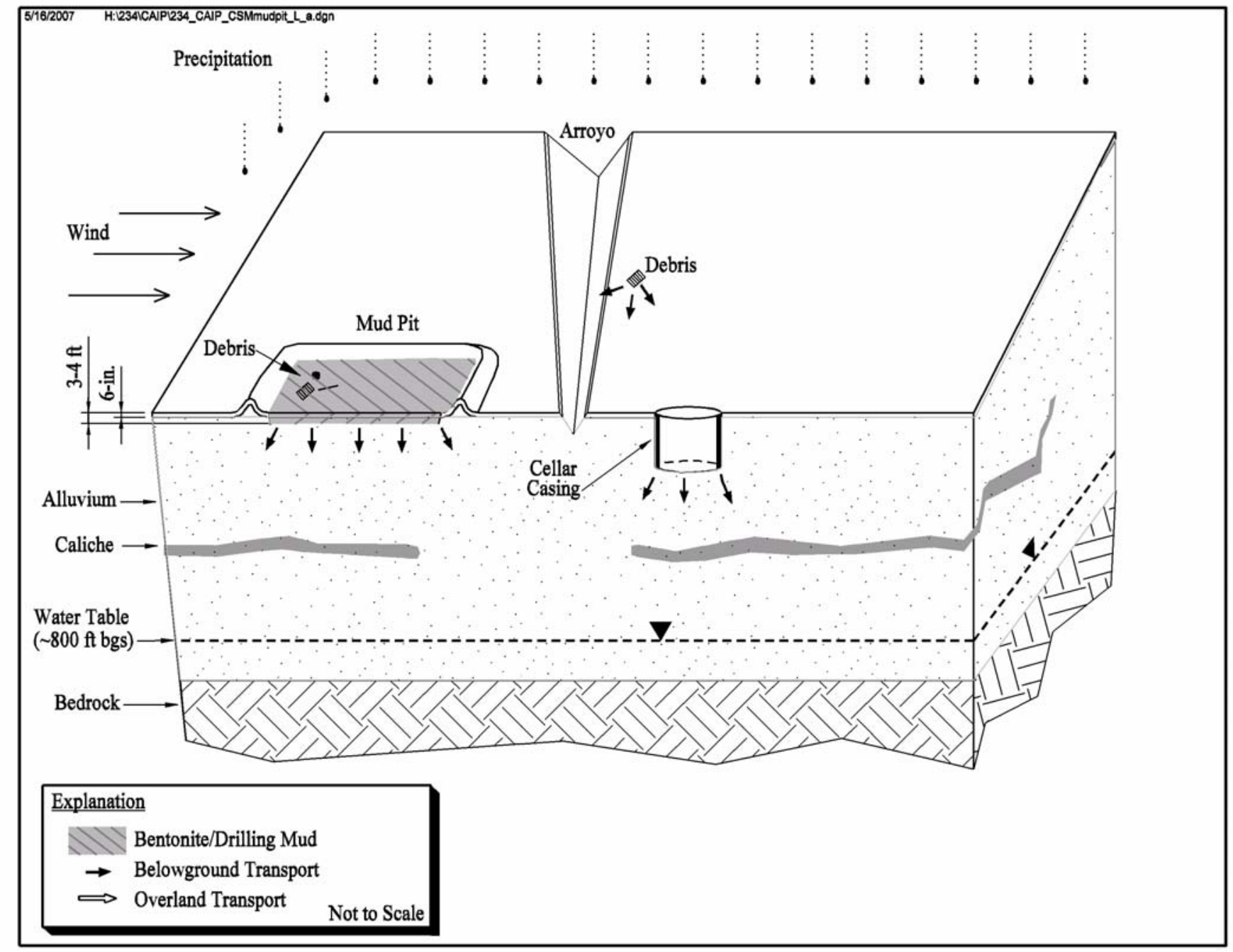

Figure 3-2

Corrective Action Unit 234 Conceptual Site Model 


\subsubsection{Land Use and Exposure Scenarios}

All CAU 234 CAS are located within the land-use zone described as the "Nuclear and High Explosive Test Zone.” This area is designated within the Nuclear Test Zone for additional underground nuclear weapons tests and outdoor high explosives tests. This zone includes compatible defense and non-defense research, development, and testing activities (DOE/NV, 1998).

All land-use zones dictate future land use and restrict current and future land use to non-residential (i.e., industrial) activities where the CAU 234 CASs are located.

Exposure scenarios for the CAU 234 CASs have been categorized into two types, based on current and projected future land uses, as follows:

- Remote Work Area for CASs 02-09-48. This exposure scenario assumes non-continuous work activities at a site. This scenario is for areas where an industrial worker may be exposed during regular visits but where the site is not an assigned work area. A site worker under this scenario is assumed to be on the site for an equivalent of 42 days per year for an entire career (25 years).

- Occasional Use Area for CASs 03-09-02, 12-09-01, 12-09-08, and 12-30-14. This exposure scenario assumes exposure to industrial workers who are not assigned to the area as a regular worksite but may occasionally use the site for intermittent or short-term activities. A site worker under this scenario is assumed to be on the site for an equivalent of 8 hours per day, 10 days per year, for 5 years.

\subsubsection{Contaminant Sources}

The contamination sources for the CSM are:

- Drums

- Pipes

- Drilling muds

- Cellar contents

\subsubsection{Release Mechanisms}

Release mechanisms for the CSM are spills, leaks, and placement of drilling muds into pits, surface soils and/or into subsurface soils from debris or retained materials. Materials stored in containers may have leaked or been spilled. Contaminants related to debris left in mud pits may have leached into subsurface soils. 


\subsubsection{Migration Pathways}

Migration is influenced by physical and chemical characteristics of the contaminants and media. Contaminant characteristics include, but are not limited to: solubility, density, and adsorption potential. Media characteristics include permeability, porosity, water saturation, sorting, chemical composition, and organic content. In general, contaminants with low solubility, high affinity for media, and high density can be expected to be found relatively close to release points. Contaminants with high solubility, low affinity for media, and low density can be expected to be found further from release points. These factors affect the migration pathways and potential exposure points for the contaminants in the various media under consideration.

Infiltration and percolation of precipitation serves as a driving force for downward migration of contaminants. However, due to high potential evapotranspiration (annual potential evapotranspiration at the Area 3 Radiological Waste Management Site has been estimated at 62.6 inches [in.] [Shott et al., 1997]) and limited precipitation for this region (6.4 in. annually [ARL/SORD, 2007]), percolation of infiltrated precipitation at the NTS does not provide a significant mechanism for vertical migration of contaminants to groundwater (DOE/NV, 1992).

Subsurface migration pathways at the CASs are expected to be predominately vertical. The depth of infiltration (shape of the subsurface contaminant plume) will be dependant upon the type, volume, and duration of the discharge, as well as the presence of relatively impermeable layers that could modify vertical or horizontal transport pathways, both on the ground surface (e.g., concrete) and in the subsurface (e.g., caliche layers).

Surface migration pathways for CASs 02-09-48, 03-09-02, and 12-09-01 include lateral movement along the surface into drainages and arroyos. Surface migration pathways at these CASs are expected to be minor, because these CASs have shallow surface slopes and the potential release sites are not located in or near drainages. Surface migration pathways for CAS 12-09-08 include lateral movement along the surface of the surrounding soil. Surface migration at CAS 12-09-08 is expected to be minor, because the CAS has shallow surface slopes, and the potential release sites are not located in or near drainages. No surface release pathway is identified for CAS 12-30-14, as the contents of the cellar begin at approximately $4 \mathrm{ft}$ bgs. 


\subsubsection{Exposure Points}

Exposure points for the CSM is expected to be areas of surface contamination where visitors and site workers will come in contact with soil surface. Subsurface exposure points may also exist if construction workers come in contact with contaminated media during excavation activities.

\subsubsection{Exposure Routes}

Exposure routes to site workers include ingestion, inhalation, and/or dermal contact (absorption) from disturbance of, or direct contact with, contaminated media. Site workers may also be exposed to radiological contamination by performing activities in proximity to radiologically contaminated materials.

\subsubsection{Additional Information}

Information concerning topography, geology, climatic conditions, hydrogeology, floodplains, and infrastructure at the CAU 234 CASs are available and are presented in Section 2.1, as they pertain to the investigation. This information has been addressed in the CSM and will be considered during the evaluation of corrective action alternatives, as applicable.

\subsection{Contaminants of Potential Concern}

The COPCs for CAU 234 are defined as the list of constituents represented by the analytical methods identified in Table 3-1 for Decision I environmental samples taken at each of the CASs. The constituents reported for each analytical method are listed in Table 3-2. 
Table 3-1

Analytical Program ${ }^{a}$

\begin{tabular}{|c|c|c|c|c|c|}
\hline Analyses & $\begin{array}{c}\text { CAS } \\
02-09-48\end{array}$ & $\begin{array}{c}\text { CAS } \\
03-09-02\end{array}$ & $\begin{array}{l}\text { CAS } \\
12-09-01\end{array}$ & $\begin{array}{l}\text { CAS } \\
12-09-08\end{array}$ & $\begin{array}{c}\text { CAS } \\
12-30-14\end{array}$ \\
\hline \multicolumn{6}{|c|}{ Organic Contaminants of Potential Concern (COPCs) } \\
\hline $\begin{array}{l}\text { Total Petroleum Hydrocarbons-Diesel-Range } \\
\text { Organics }\end{array}$ & $\mathrm{X}$ & $x$ & $\mathrm{X}$ & $\mathrm{X}$ & $\mathrm{X}$ \\
\hline $\begin{array}{l}\text { Total Petroleum Hydrocarbons-Gasoline-Range } \\
\text { Organics }\end{array}$ & $x$ & $\mathrm{X}$ & $\mathrm{X}$ & $\mathrm{X}$ & $\mathrm{X}$ \\
\hline Polychlorinated Biphenyls & $\mathrm{X}$ & $\mathrm{X}$ & $\mathrm{X}$ & $\mathrm{X}$ & $\mathrm{X}$ \\
\hline Semivolatile Organic Compounds & $\mathrm{X}$ & $\mathrm{X}$ & $\mathrm{X}$ & $\mathrm{X}$ & $\mathrm{X}$ \\
\hline Volatile Organic Compounds & $\mathrm{X}$ & $\mathrm{X}$ & $\mathrm{X}$ & $\mathrm{X}$ & $X$ \\
\hline \multicolumn{6}{|c|}{ Inorganic COPCs } \\
\hline Resource Conservation and Recovery Act Metals & $\mathrm{X}$ & $\mathrm{X}$ & $\mathrm{X}$ & $\mathrm{X}$ & $\mathrm{X}$ \\
\hline Beryllium & $\mathrm{X}$ & $\mathrm{X}$ & $\mathrm{X}$ & $\mathrm{X}$ & $\mathrm{X}$ \\
\hline \multicolumn{6}{|c|}{ Radionuclide COPCs } \\
\hline Gamma Spectroscopy & $\mathrm{X}$ & $\mathrm{X}$ & $\mathrm{X}$ & $\mathrm{X}$ & $\mathrm{X}$ \\
\hline Isotopic Uranium & $\mathrm{X}$ & $\mathrm{X}$ & $\mathrm{X}$ & $X$ & $\mathrm{X}$ \\
\hline Isotopic Plutonium & $\mathrm{X}$ & $\mathrm{X}$ & $x$ & $\mathrm{X}$ & $\mathrm{X}$ \\
\hline Strontium-90 & $X$ & $X$ & $X$ & $X$ & $X$ \\
\hline
\end{tabular}

\footnotetext{
${ }^{\mathrm{a}}$ The contaminants of potential concern are the constituents reported from the analytical methods listed.

$\mathrm{X}=$ Required analytical method
}

The list of COPCs is intended to encompass all of the contaminants that could potentially be present at each CAS. These COPCs were identified during the planning process through the review of site history, process knowledge, personal interviews, past investigation efforts (where available), and inferred activities associated with the CASs. Contaminants detected at similar NTS sites were also included in the COPC list to reduce the uncertainty about potential contamination at the CASs, because complete information regarding activities performed at the CAU 234 sites is not available. 
Table 3-2

\section{Constituents Reported by Analytical Methods}

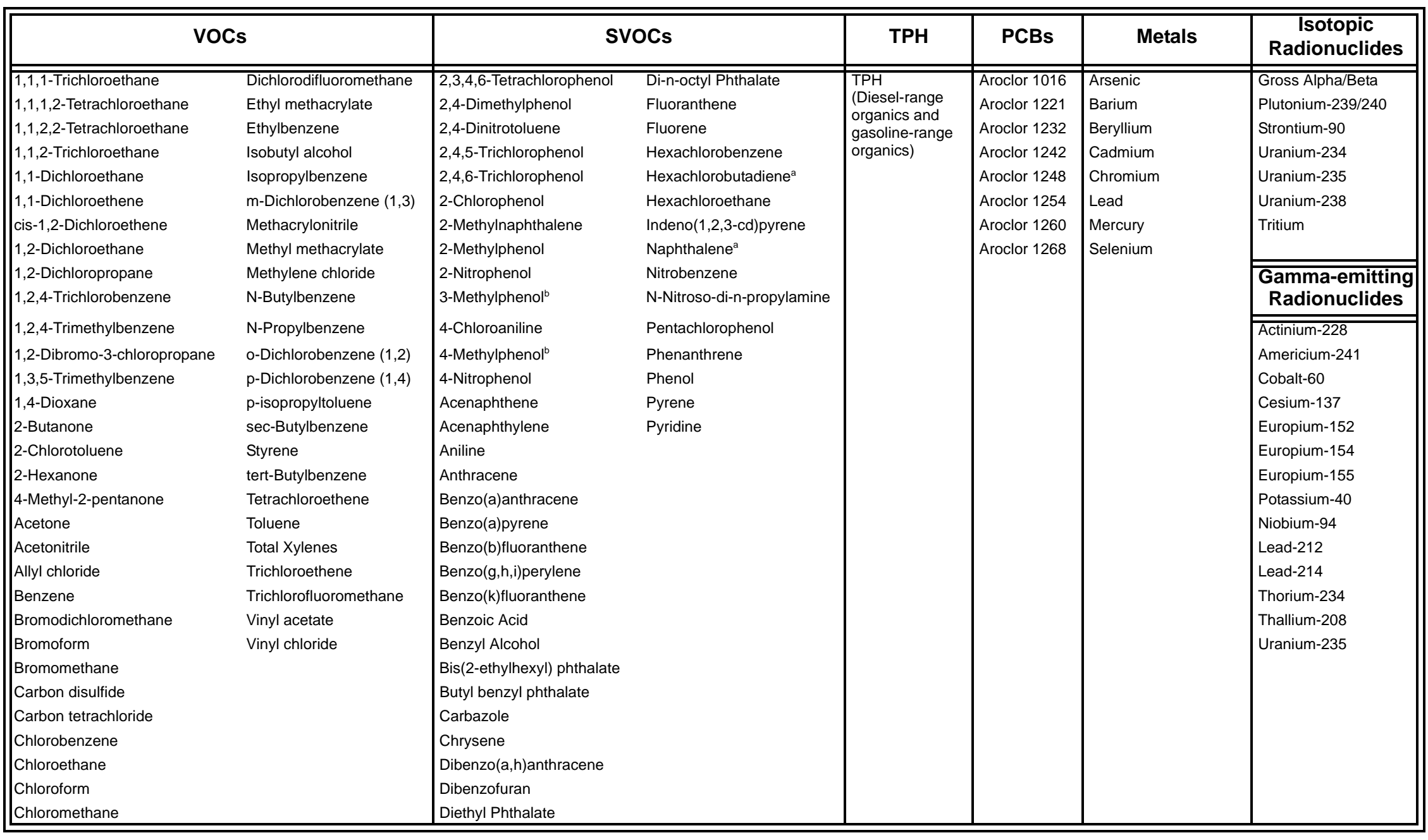

aMay be reported with VOCs

'May be reported as 3,4-methylpenol 


\subsection{Preliminary Action Levels}

The PALs presented in this section are to be used for site screening purposes. They are not intended to be used as cleanup action levels or FALs. However, they are useful in screening out contaminants that are not present in sufficient concentrations to warrant further evaluation, thereby streamlining the consideration of remedial alternatives. The risk-based corrective action (RBCA) process used to establish FALs is described in the Industrial Sites Project Establishment of Final Action Levels (NNSA/NSO, 2006b). This process conforms with Nevada Administrative Code (NAC)

Section 445A.227, which lists the requirements for sites with soil contamination (NAC, 2006c). For the evaluation of corrective actions, NAC Section 445A.22705 (NAC, 2006d) requires the use of American Society for Testing and Materials (ASTM) Method E 1739-95 (ASTM, 1995) to "conduct an evaluation of the site, based on the risk it poses to public health and the environment, to determine the necessary remediation standards (i.e., FALs) or to establish that corrective action is not necessary."

This RBCA process, summarized in Figure 3-3, defines three tiers (or levels) of evaluation involving increasingly sophisticated analyses:

- Tier 1 evaluation - Sample results from source areas (highest concentrations) are compared to action levels based on generic (non-site-specific) conditions (i.e., the PALs established in the CAIP). The FALs may then be established as the Tier 1 action levels or the FALs may be calculated using a Tier 2 evaluation.

- Tier 2 evaluation - Conducted by calculating Tier 2 site-specific target levels (SSTLs) using site-specific information as inputs to the same or similar methodology used to calculate Tier 1 action levels. The Tier 2 SSTLs are then compared to individual sample results from reasonable points of exposure (as opposed to the source areas as is done in Tier 1) on a point-by-point basis. The TPH concentrations will not be used for risk-based decisions under Tier 2 or Tier 3. Rather, the individual chemicals of concern will be compared to the SSTLs.

- Tier 3 evaluation - Conducted by calculating Tier 3 SSTLs on the basis of more sophisticated risk analyses using methodologies described in ASTM Method E 1739-95 that consider site-, pathway-, and receptor-specific parameters. 


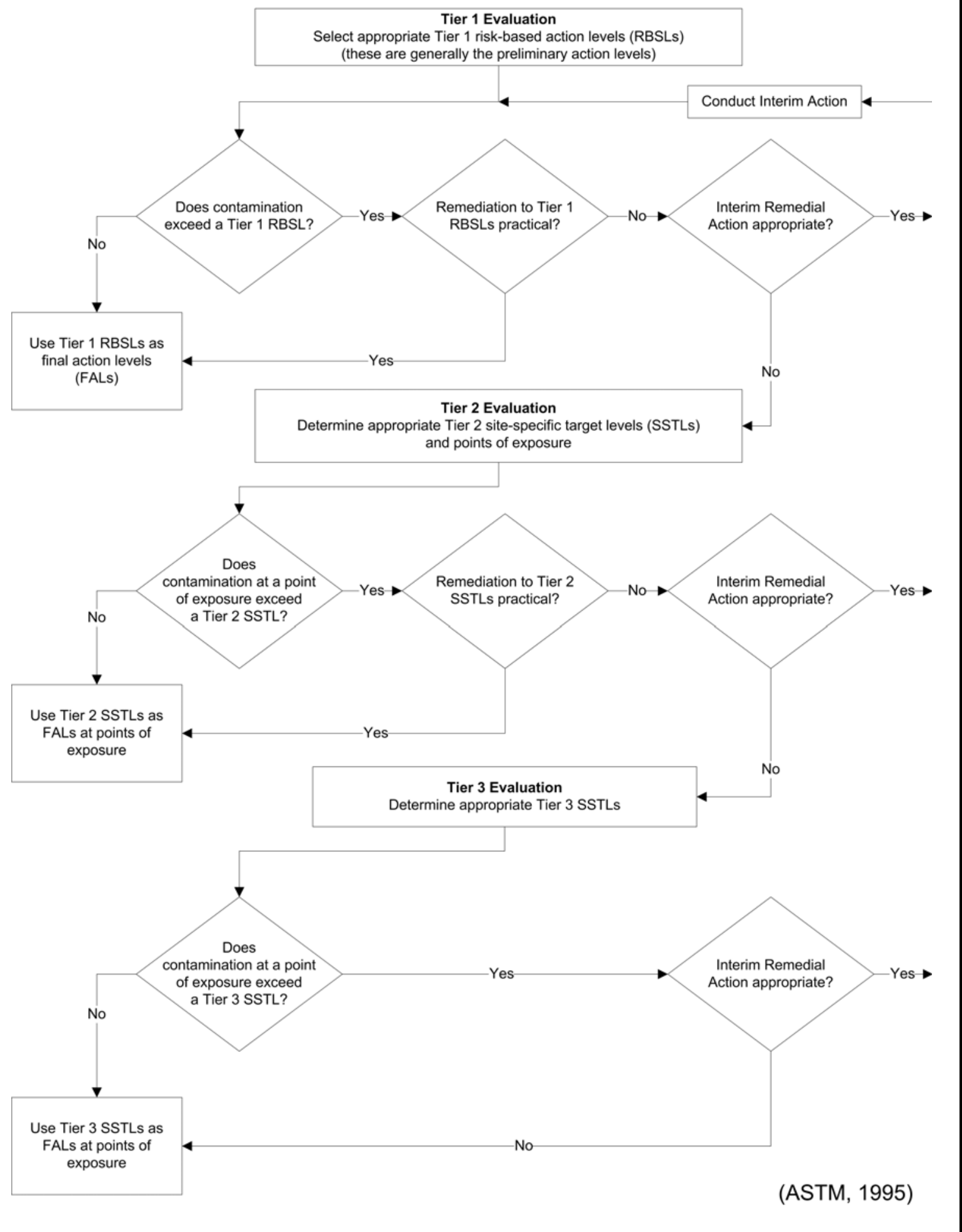

Figure 3-3

Risk-Based Corrective Action Decision Process 
This process includes a provision for conducting an interim remedial action if necessary and appropriate. The decision to conduct an interim action may be made at any time during the investigation and at any level (tier) of analysis. Concurrence of the decision-makers listed in Section A.3.1 will be obtained before any interim action is implemented. Evaluation of DQO decisions will be based on conditions at the site following completion of any interim actions. Any interim actions conducted will be reported in the investigation report.

The FALs (along with the basis for selection) will be proposed in the investigation report, where they will be compared to laboratory results in the evaluation of potential corrective actions.

\subsubsection{Chemical PALs}

Except as noted herein, the chemical PALs are defined as the U.S. Environmental Protection Agency (EPA) Region 9 Risk-Based Preliminary Remediation Goals (PRGs) for contaminant constituents in industrial soils (EPA, 2004a). Background concentrations for RCRA metals will be used instead of PRGs when natural background concentrations exceed the PRG, which is often the case with arsenic on the NTS. Background is considered the mean plus two standard deviations of the mean for sediment samples collected by the Nevada Bureau of Mines and Geology throughout the Nevada Test and Training Range (formerly the Nellis Air Force Range) (NBMG, 1998; Moore, 1999). For detected chemical COPCs without established PRGs, the protocol used by the EPA Region 9 in establishing PRGs (or similar) will be used to establish PALs. If used, this process will be documented in the investigation report.

\subsubsection{Total Petroleum Hydrocarbon PALs}

The PAL for TPH is 100 parts per million (ppm) as listed in NAC 445A.2272 (NAC, 2006e).

\subsubsection{Radionuclide PALs}

The PALs for radiological contaminants (other than tritium) are based on the National Council on Radiation Protection and Measurement (NCRP) Report No. 129 recommended screening limits for construction, commercial, industrial land-use scenarios (NCRP, 1999) using a 25 millirem per year (mrem/yr) dose constraint (Murphy, 2004) and the generic guidelines for residual concentration of radionuclides in DOE Order 5400.5 (DOE, 1993). These PALs are based on the construction, 
commercial, and industrial land-use scenario provided in the guidance and are appropriate for the NTS based on future land use scenarios as presented in Section 3.1.1.

The PAL for tritium is based on the Underground Test Area (UGTA) Project limit of 400,000 picocuries per liter (pCi/L) for discharge of water containing tritium (NNSA/NV, 2002b). The activity of tritium in the soil moisture of soil samples will be reported in units of $\mathrm{pCi} / \mathrm{L}$ for comparison to this PAL.

Solid media such as concrete and/or structures may pose a potential radiological exposure risk to site workers if contaminated. The radiological PAL for solid media will be defined as the unrestricted-release criteria defined in the NV/YMP Radiological Control (RadCon) Manual (NNSA/NSO, 2004).

\subsection{Data Quality Objective Process Discussion}

This section contains a summary of the DQO process that is presented in Appendix A. The DQO process is a strategic planning approach based on the scientific method that is designed to ensure that the data collected will provide sufficient and reliable information to identify, evaluate, and technically defend the recommendation of viable corrective actions (e.g., no further action, clean closure, or closure in place).

The DQO strategy for CAU 234 was developed at a meeting on April 12, 2007. The DQOs were developed to identify data needs, clearly define the intended use of the environmental data, and to design a data collection program to satisfy these purposes. During the DQO discussions for CAU 234, the informational inputs or data needs to resolve problem statements and decision statements were documented.

The problem statement for CAU 234 is: "Existing information on the nature and extent of potential contamination is insufficient to evaluate and recommend corrective action alternatives for the CASs in CAU 234." To address this question, the resolution of two decisions statements is required:

- Decision I: “Is any COC present in environmental media within the CAS?” If a COC is detected, then Decision II must be resolved. Otherwise, the investigation for that CAS is complete. 
- Decision II: "If a COC is present, is sufficient information available to evaluate potential corrective action alternatives?” Sufficient information is defined to include:

- Identifying the volume of media containing any COC bounded by analytical sample results in lateral and vertical directions.

- The information needed to determine potential remediation waste types.

The presence of a COC would require a corrective action. A corrective action may also be necessary if there is a potential for wastes that are present at a site to impose COCs into site environmental media if the wastes were to be released. To evaluate the potential for the cellar contents of CAS 12-30-14 to result in the introduction of a COC into the surrounding environmental media, the following conservative assumptions were made:

- The cellar containment would fail at some point and the contents would be released to the surrounding media.

- The resulting concentration of contaminants in the surrounding media would be equal to the concentration of contaminants in the cellar waste.

- Any liquid contaminant in the cellar exceeding the RCRA toxicity characteristic concentration can result in the introduction of a COC to the surrounding media.

Sediment containing a contaminant exceeding an equivalent FAL concentration would be considered a potential source material and require a corrective action. Cellar liquids with contaminant concentrations exceeding an equivalent toxicity characteristic action level would be considered to be potential source material and would require a corrective action.

Decision I samples will be submitted to analytical laboratories for the analyses listed in Table 3-1. Decision II samples will be submitted for the analysis of all unbounded COCs. In addition, samples will be submitted for analyses as needed to support waste management or health and safety decisions.

The data quality indicators (DQIs) of precision, accuracy, representativeness, completeness, comparability, and sensitivity needed to satisfy DQO requirements are discussed in Section 6.2. Laboratory data will be assessed in the investigation report to confirm or refute the CSM and determine whether the DQO data needs were met. 
To satisfy the DQI of sensitivity (see Section 6.2.8), the analytical methods must be sufficient to detect contamination that is present in the samples at concentrations less than or equal to the corresponding FALs. Analytical methods for each CAU 234 COPC are provided in Tables 3-3 and 3-4. Due to changes in analytical methodology and changes in analytical laboratory contracts, information in Tables 3-3 and 3-4 that varies from corresponding information in the QAPP will supersede the QAPP specifications (NNSA/NV, 2002a).

Table 3-3

Analytical Requirements for Radionuclides for CAU 234

(Page 1 of 2)

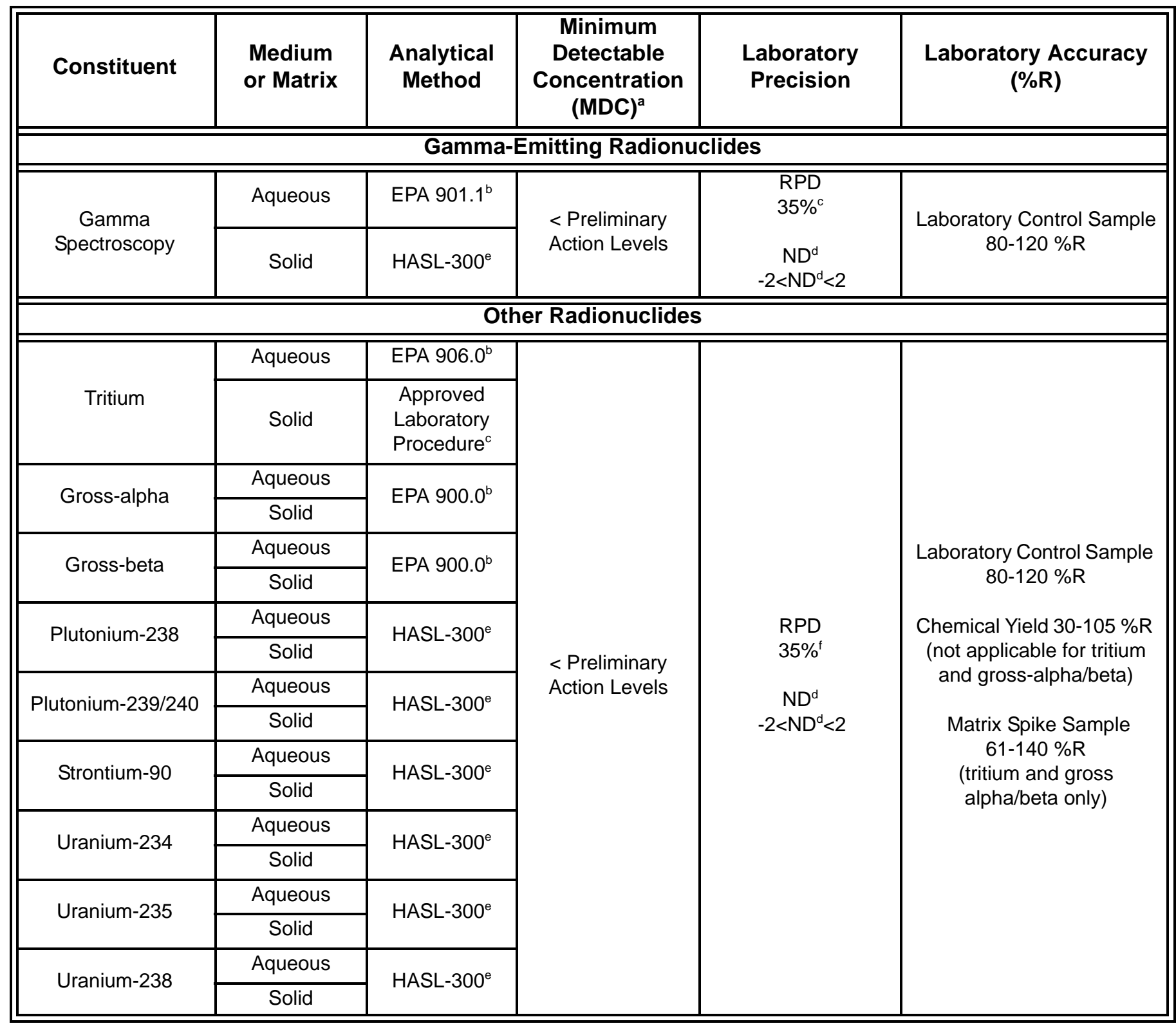


Table 3-3

Analytical Requirements for Radionuclides for CAU 234

(Page 2 of 2)

\begin{tabular}{||c|c|c|c|c|c|}
\hline Constituent & $\begin{array}{c}\text { Medium } \\
\text { or Matrix }\end{array}$ & $\begin{array}{c}\text { Analytical } \\
\text { Method }\end{array}$ & $\begin{array}{c}\text { Minimum } \\
\text { Detectable } \\
\text { Concentration } \\
\text { (MDC) }\end{array}$ & $\begin{array}{c}\text { Laboratory } \\
\text { Precision }\end{array}$ & $\begin{array}{c}\text { Laboratory Accuracy } \\
(\% R)\end{array}$ \\
\hline
\end{tabular}

${ }^{a}$ The MDC is the lowest concentration of a radionuclide present in a sample and can be detected with a $95 \%$ confidence level.

${ }^{\mathrm{b}}$ Prescribed Procedures for Measurement of Radioactivity in Drinking Water (EPA, 1980).

'Laboratory procedure must be approved by appropriate project personnel.

${ }^{d} \mathrm{ND}$ is not RPD; rather, it is another measure of precision used to evaluate duplicate analyses. The ND is calculated as the difference between two results divided by the square root of the sum of the squares of their total propagated uncertainties. Evaluation of

Radiochemical Data Usability (DOE, 1997a).

${ }^{\mathrm{e}}$ The Procedures Manual of the Environmental Measurements Laboratory, HASL-300 (DOE, 1997b).

'Sampling and Analysis Plan (Field Sampling Plan and Quality Assurance Project Plan) with Guidance (EPA, 2002).

EPA $=$ U.S. Environmental Protection Agency

HASL $=$ Health and Safety Laboratory

ND = Normalized difference

$\mathrm{RPD}=$ Relative percent difference

$\% \mathrm{R}=$ Percent recovery

Table 3-4

Analytical Requirements for Chemical COPCs for CAU 234

(Page 1 of 2)

\begin{tabular}{|c|c|c|c|c|c|}
\hline Analysis $^{a}$ & Matrix & $\begin{array}{l}\text { Analytical } \\
\text { Method } \\
(\mathrm{SW}-846)^{\mathrm{b}}\end{array}$ & $\begin{array}{c}\text { Minimum } \\
\text { Detectable } \\
\text { Concentration } \\
\text { (MDC) }^{c}\end{array}$ & $\begin{array}{l}\text { Laboratory } \\
\text { Precision }\end{array}$ & $\begin{array}{c}\text { Laboratory } \\
\text { Accuracy } \\
\text { (\%R) }\end{array}$ \\
\hline \multicolumn{6}{|c|}{ ORGANICS } \\
\hline \multirow{2}{*}{$\begin{array}{l}\text { Total Volatile Organic } \\
\text { Compounds }\end{array}$} & Aqueous & \multirow{2}{*}{$8260 \mathrm{~B}$} & \multirow{2}{*}{$\begin{array}{l}<\text { Preliminary } \\
\text { Action Levels }\end{array}$} & \multirow{2}{*}{ Lab-specific $^{d}$} & \multirow{2}{*}{ Lab-specific $^{d}$} \\
\hline & Solid & & & & \\
\hline \multirow{2}{*}{$\begin{array}{l}\text { Total Semivolatile Organic } \\
\text { Compounds }\end{array}$} & Aqueous & \multirow{2}{*}{$8270 \mathrm{C}$} & \multirow{2}{*}{$\begin{array}{l}<\text { Preliminary } \\
\text { Action Levels }\end{array}$} & \multirow{2}{*}{ Lab-specific $^{d}$} & \multirow{2}{*}{ Lab-specific $^{d}$} \\
\hline & Solid & & & & \\
\hline \multirow{2}{*}{ Polychlorinated Biphenyls } & Aqueous & \multirow{2}{*}{8082} & \multirow{6}{*}{$\begin{array}{l}<\text { Preliminary } \\
\text { Action Levels }\end{array}$} & \multirow{2}{*}{ Lab-specific $^{d}$} & \multirow{2}{*}{ Lab-specific ${ }^{d}$} \\
\hline & Solid & & & & \\
\hline \multirow{2}{*}{$\begin{array}{l}\text { Total Petroleum Hydrocarbons- } \\
\text { Gasoline-Range Organics }\end{array}$} & Aqueous & \multirow{2}{*}{$\begin{array}{c}\text { 8015B } \\
\text { (modified) }\end{array}$} & & \multirow{2}{*}{ Lab-specific $^{d}$} & \multirow{2}{*}{ Lab-specific $^{d}$} \\
\hline & Solid & & & & \\
\hline \multirow{2}{*}{$\begin{array}{l}\text { Total Petroleum Hydrocarbons- } \\
\text { Diesel-Range Organics }\end{array}$} & Aqueous & \multirow{2}{*}{$\begin{array}{c}\text { 8015B } \\
\text { (modified) }\end{array}$} & & \multirow{2}{*}{ Lab-specific $^{d}$} & \multirow{2}{*}{ Lab-specific $^{d}$} \\
\hline & Solid & & & & \\
\hline
\end{tabular}


Table 3-4

Analytical Requirements for Chemical COPCs for CAU 234 (Page 2 of 2)

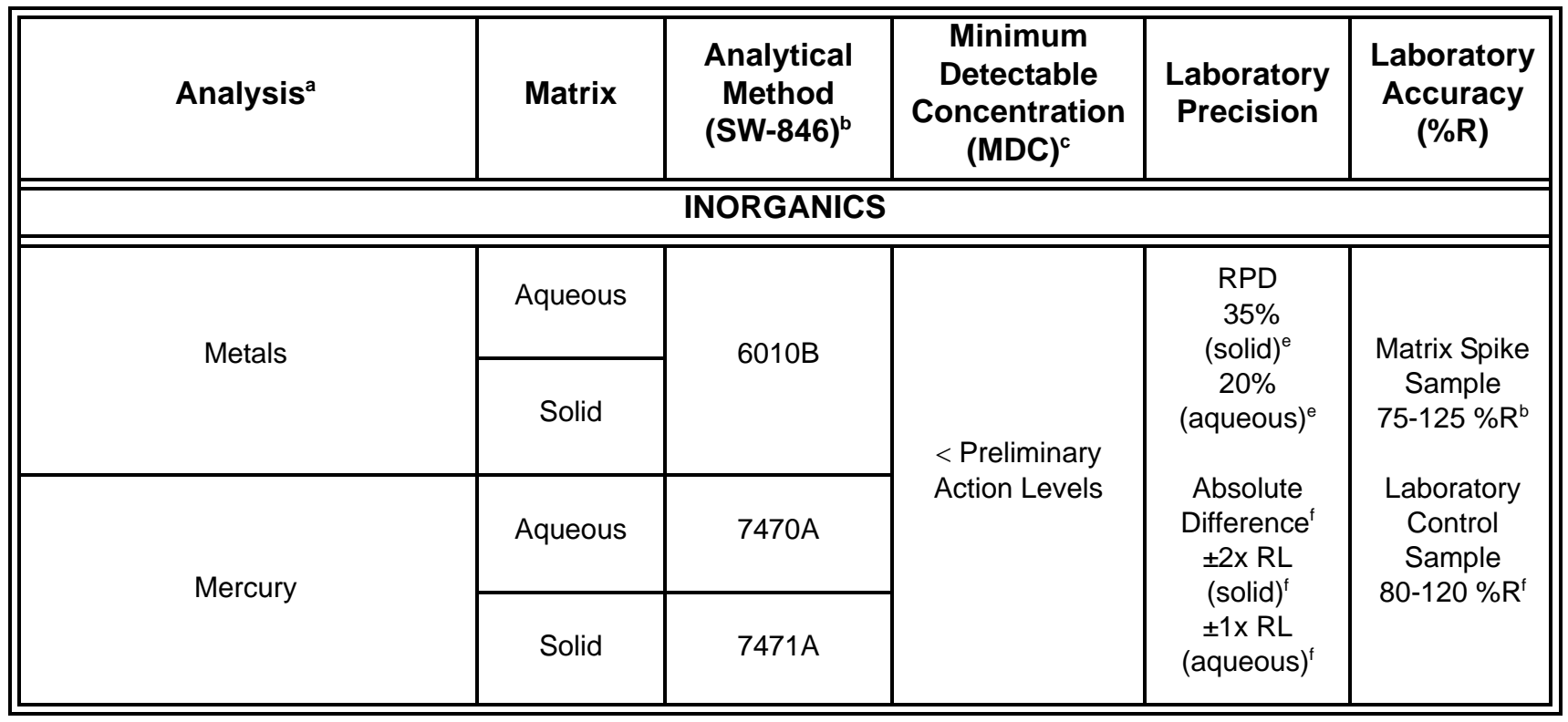

${ }^{\mathrm{a} A p p l i c a b l e ~ c o n s t i t u e n t s ~ a r e ~ l i s t e d ~ i n ~ T a b l e ~ 3-2 . ~}$

${ }^{\mathrm{b}}$ Test Methods for Evaluating Solid Waste, Physical/Chemical Methods (SW-846) (EPA, 1996)

${ }^{\mathrm{C}}$ The MDC is the lowest concentration that can be reliably achieved within specified limits of accuracy and precision. ${ }^{\mathrm{d}} \mathrm{RPD}$ and \%R performance criteria are developed by the analytical laboratory according to approved procedures.

e Sampling and Analysis Plan (Field Sampling Plan and Quality Assurance Project Plan) with Guidance (EPA, 2002)

${ }^{f}$ U.S. EPA Contract Laboratory Program National Functional Guidelines for Inorganic Data Review (EPA, 2004b)

MDC = Minimum detectable concentration

$\mathrm{RL}=$ Reporting limit

$\mathrm{RPD}=$ Relative percent difference

$\% \mathrm{R}=$ Percent recovery

$<=$ Less than

$\pm=$ Plus or minus 


\subsection{Field Investigation}

This section contains a description of the activities to be conducted to gather and document information from the CAU 234 field investigation.

\subsection{Technical Approach}

The information necessary to satisfy the DQO data needs will be generated for each CAU 234 CAS (see Section 1.2.1) for investigation by collecting and analyzing samples generated during a field investigation. The presence and nature of contamination at each CAS will be evaluated using a judgmental approach.

If there is a waste present that, if released, has the potential to release significant contamination into site environmental media, that waste will be sampled. If it is determined that a COC is present at any CAS, that CAS will be further addressed by determining the extent of contamination before evaluating corrective action alternatives.

Because this CAIP only addresses contamination originating from the CAU, it may be necessary to distinguish overlapping contamination originating from other sources. For example, widespread surface radiological contamination originating from atmospheric tests will not be addressed in the CAU 234 investigation. To determine whether contamination is from the CAU or from other sources, soil samples may be collected from locations outside the influence of releases from the CAS at selected CASs.

Modifications to the investigative strategy may be required should unexpected field conditions be encountered at any CAS. Significant modifications shall be justified and documented before implementation. If an unexpected condition indicates that conditions are significantly different than the corresponding CSM, the activity will be rescoped and the identified decision-makers notified. 


\subsection{Field Activities}

Field activities at CAU 234 include site preparation, sample location selection, and sample collection.

\subsubsection{Site Preparation Activities}

Site preparation activities conducted by the NTS Management and Operating Contractor before the investigation may include, but not be limited to: relocation or removal of surface debris, equipment, and structures; construction of hazardous waste accumulation areas (HWAAs) and site exclusion zones, providing sanitary facilities; construction of decontamination facilities; and temporarily moving staged equipment.

Before mobilization for collecting investigation samples, the following preparatory activities will also be performed:

- $\quad$ Radiological surveys of CAS 03-09-02.

- Visual surveys at the CASs within CAU 234 listed in Section 1.2.1 to identify any staining, discoloration, disturbance of native soils, or any other indication of potential contamination.

\subsubsection{Sample Location Selection}

At each CAS, biasing factors (including field-screening results) will be used to select the most appropriate samples from a particular location for submittal to the analytical laboratory. Biasing factors to be used for selection of sampling locations are listed in Section A.5.2.1. As biasing factors are identified and used for selection of sampling locations, they will be documented in the appropriate field documents.

The CAS-specific sampling strategy and the estimated locations of biased samples for each CAS are presented in Appendix A. The number, location, and spacing of step-outs may be modified by the Task Manager or Site Supervisor, as warranted by site conditions, to achieve DQO criteria stipulated in Appendix A. Where sampling locations are modified by the Task Manager or Site Supervisor, the justification for these modifications will be documented in the field logbook. 


\subsubsection{Sample Collection}

The CAU 234 sampling collection activities will consist of the following:

- Collect and analyze samples from locations as described in this section.

- Collect required QC samples.

- Collect waste management samples.

- Collect soil samples from locations outside the influence of releases from the CAS, if necessary.

- Perform radiological characterization surveys of construction materials and debris as necessary for disposal purposes.

- Record Global Positioning System coordinates for each environmental sample location.

Decision I surface soil samples ( 0 to $0.5 \mathrm{ft}$ bgs) will be collected. If biasing factors are present in soils below locations where Decision I samples were collected, subsurface Decision I soil samples will also be collected by hand augering, backhoe excavation, direct-push, or drilling techniques, as appropriate. Decision I subsurface soil samples will collected at depth intervals selected by the Task Manager or Site Supervisor based on biasing factors to a depth where the biasing factors are no longer present.

The content of the CAS 12-30-14 cellar will be sampled to characterize the contents as potential source material.

Decision II sampling will consist of further defining the extent of contamination where COCs have been confirmed. Step-out (Decision II) sampling locations at each CAS will be selected based on the CSM, biasing factors, field-screening results, existing data, and the outer boundary sample locations where COCs were detected. In general, step-out sample locations will be arranged in a triangular pattern around areas containing a $\mathrm{COC}$ at distances based on site conditions, COC concentrations, process knowledge, and biasing factors. If COCs extend beyond step-out locations, additional Decision II samples will be collected from locations further from the source. If a spacial boundary is reached, the CSM is shown to be inadequate, or the Site Supervisor determines that extent sampling needs to be re-evaluated, work will be temporarily suspended, NDEP notified, and the investigation 
strategy re-evaluated. A minimum of one analytical result less than the action level from each lateral and vertical direction will be required to define the extent of COC contamination. The lateral and vertical extent of COCs will only be established based on validated laboratory analytical results (i.e., not field screening).

\subsubsection{Sample Management}

The laboratory requirements to be used when analyzing the COPCs are presented in Tables 3-3 and 3-4. The analytical program for each CAS is presented in Table 3-1. All sampling activities and QC requirements for field and laboratory environmental sampling will be conducted in compliance with the Industrial Sites QAPP (NNSA/NV, 2002a) and other applicable, approved procedures.

\subsection{Safety}

A site-specific health and safety document will be prepared and approved before the field effort. As required by the DOE Integrated Safety Management System (ISMS) (DOE/NV, 1997), this document outlines the requirements for protecting the health and safety of the workers and the public. The ISMS program requires that site personnel will reduce or eliminate the possibility of injury, illness, or accidents, and to protect the environment during all project activities. Safety issues will be taken into consideration when evaluating the hazards and associated control procedures for field activities as follows:

- Potential hazards to site personnel and the public include, but are not limited to: radionuclides, chemicals (e.g., heavy metals, VOCs, SVOCs, and petroleum hydrocarbons), adverse and rapidly changing weather, remote location, and motor vehicle and heavy equipment operations.

- $\quad$ Proper training of all site personnel to recognize and mitigate the anticipated hazards.

- Work controls to reduce or eliminate the hazards including engineering controls, substitution of less hazardous materials, and use of appropriate personal protective equipment (PPE).

- Occupational exposure monitoring to prevent overexposures to hazards such as radionuclides, chemicals, and physical agents (e.g., heat, cold, and high wind).

- Radiological surveying for alpha/beta and gamma emitters to minimize and/or control personnel exposures; use of the "as-low-as-reasonably-achievable” principle when addressing radiological hazards. 
- Emergency and contingency planning to include medical care and evacuation, decontamination, spill control measures, and appropriate notification of project management. The same principles apply to emergency communications.

\subsection{Site Restoration}

Following completion of CAI and waste management activities, the following actions will be implemented before closure of the site Real Estate/Operations Permit:

- Removal of all equipment, wastes, debris, and materials associated with the CAI.

- Removal of all signage and fencing (unless part of a corrective action).

- Grading of site to pre-investigation condition (unless changed condition is necessary under a corrective action).

- Site will be inspected and certified that restoration activities have been completed. 


\subsection{Waste Management}

Management of IDW will be based on regulatory requirements, field observations, process knowledge, and laboratory results from CAU 234 investigation samples.

Investigation-derived waste that consists of disposable sampling equipment, PPE, and rinsate are considered potentially contaminated waste only by virtue of contact with potentially contaminated media (e.g., soil) or potentially contaminated debris (e.g., construction materials). Therefore, sampling and analysis of IDW, separate from analyses of site investigation samples, may not be necessary for all IDW. However, if associated investigation samples are found to contain contaminants above regulatory levels, conservative estimates of total waste contaminant concentrations may be made based on the mass of the waste, the amount of contaminated media contained in the waste, and the maximum concentration of contamination found in the media. Direct samples of IDW may also be taken to support waste characterization.

Sanitary, hazardous, radioactive, and/or mixed waste, if generated, will be managed and disposed of in accordance with applicable DOE orders, U.S. Department of Transportation (DOT) regulations, state and federal waste regulations, and agreements and permits between DOE and NDEP.

\subsection{Waste Minimization}

Investigation activities are planned to minimize IDW generation. This will be accomplished by incorporating the use of process knowledge, visual examination, and/or radiological survey and swipe results. When possible, disturbed media (such as soil removed during trenching) or debris will be returned to its original location. Contained media (e.g., soil managed as waste) as well as other IDW will be segregated to the greatest extent possible to minimize generation of hazardous, radioactive, or mixed waste. Hazardous material used at the sites will be controlled in order to limit unnecessary generation of hazardous or mixed waste. Administrative controls, including decontamination procedures and waste characterization strategies, will minimize waste generated during investigations. 


\subsection{Potential Waste Streams}

Waste generated during the investigation activities will include the following potential waste streams:

- Personal protective equipment and disposable sampling equipment (e.g., plastic, paper, sample containers, aluminum foil, spoons, bowls)

- Decontamination rinsate

- Environmental media (e.g., soil)

- Surface debris in investigation area (e.g., 55-gal drums)

- Lubricants/fuels from heavy equipment (e.g., hydraulic fluids)

- Field-screening waste (e.g., disposable sampling equipment, and/or PPE contaminated by field-screening activities)

\subsection{Investigation-Derived Waste Management}

The onsite management and ultimate disposition of IDW will be determined based on a determination of the waste type (e.g., sanitary, low-level radioactive, hazardous, hydrocarbon), or the combination of waste types (e.g., hazardous/mixed low-level [MLLW]). A determination of the waste type will be guided by several factors, including, but not limited to: the analytical results of samples directly or indirectly associated with the waste, historical site knowledge, knowledge of the waste generation process, field observations, field-monitoring/screening results, and/or radiological survey/swipe results.

Table 4-2 of the NV/YMP RadCon Manual (NNSA/NSO, 2004) shall be used to determine whether such materials may be declared nonradioactive. Onsite IDW management requirements by waste type are detailed in the following sections. Applicable waste management regulations and requirements are listed in Table 5-1. 
Table 5-1

Waste Management Regulations and Requirements

\begin{tabular}{|c|c|c|}
\hline Waste Type & Federal Regulation & Additional Requirements \\
\hline Solid (non-hazardous) & N/A & $\begin{array}{c}\text { NRS }^{\mathrm{a}} 444.440-444.620 \\
\text { NAC }^{\mathrm{b}} 444.570-444.7499 \\
\text { NTS Landfill Permit SW13.097.04 } \\
\text { NTS Landfill Permit SW13.097.03 } 5 \\
\text { Rev. } 7\end{array}$ \\
\hline Liquid/Rinsate (non-hazardous) & $\mathrm{N} / \mathrm{A}$ & $\begin{array}{l}\text { Water Pollution Control General Permit } \\
\text { GNEV93001, Rev. 3ive }\end{array}$ \\
\hline Hazardous & $\begin{array}{c}\text { RCRA }^{f}, \\
40 \text { CFR 260-282 }\end{array}$ & $\begin{array}{c}\text { NRS }^{a} 459.400-459.600 \\
\text { NAC }^{b} 444.850-444.8746 \\
\text { POC }^{g}\end{array}$ \\
\hline Low-Level Radioactive & $\mathrm{N} / \mathrm{A}$ & $\begin{array}{l}\text { DOE Orders } \\
\text { NTSWAC }^{\mathrm{h}}\end{array}$ \\
\hline Mixed & $\begin{array}{c}\text { RCRA }^{f}, \\
40 \text { CFR 260-282 }\end{array}$ & $\begin{array}{l}\text { POC }^{g} \\
\text { NTSWAC }^{h}\end{array}$ \\
\hline Hydrocarbons & $\mathrm{N} / \mathrm{A}$ & $\begin{array}{c}\text { NTS Landfill Permit SW13.097.02 Rev. } 7 \\
\text { NAC }^{\text {b }} \text { 445A.2272 }\end{array}$ \\
\hline Polychlorinated Biphenyls & $\begin{array}{l}\text { TSCA } \\
40 \text { CFR } 761\end{array}$ & $\begin{array}{l}\text { NRS }^{\mathrm{a}} 459.400-459.600 \\
\text { NAC }^{\mathrm{b}} 444.940-444.9555\end{array}$ \\
\hline Asbestos & $\begin{array}{c}\text { TSCA }^{\mathrm{j}} \\
40 \text { CFR } 763 \\
\text { Subpart E; } \\
40 \text { CFR } 61, \text { Subpart M }\end{array}$ & $\begin{array}{l}N_{R S}^{a} 618.750-618.840 \\
N^{\prime} C^{b} 444.965-444.976\end{array}$ \\
\hline
\end{tabular}

aNevada Revised Statutes (NRS, 2005a, b, c)

${ }^{\mathrm{b}} \mathrm{Nevada}$ Administrative Code (NAC, 2006a and e)

${ }^{c}$ Area 23 Class II Solid Waste Disposal Site (NDEP, 2006a)

${ }^{\text {dArea }} 9$ Class III Solid Waste Disposal Site (NDEP, 2006c)

eNevada Test Site Sewage Lagoons Permit (NDEP, 2005)

${ }^{\mathrm{f}}$ Resource Conservation and Recovery Act (CFR, 2006a)

${ }^{9}$ Nevada Test Site Performance Objective for the Certification of Nonradioactive Hazardous Waste (BN, 1999)

${ }^{\mathrm{h}}$ Nevada Test Site Waste Acceptance Criteria, Rev. 6-02 (NNSA/NSO, 2006c)

'Area 6 Class III Solid Waste Disposal Site for Hydrocarbon Waste (NDEP, 2006b)

'Toxic Substance Control Act (CFR, 2006b and c)

CFR $=$ Code of Federal Regulations

DOE $=$ U.S. Department of Energy

$\mathrm{N} / \mathrm{A}=$ Not applicable

NAC = Nevada Administrative Code

NRS $=$ Nevada Revised Statutes

NTS $=$ Nevada Test Site

NTSWAC = Nevada Test Site Waste Acceptance Criteria

$\mathrm{POC}=$ Performance Objective for the Certification of Nonradioactive Hazardous Waste

RCRA = Resource Conservation and Recovery Act

TSCA = Toxic Substance Control Act 


\subsubsection{Sanitary Waste}

Sanitary IDW generated at each CAS will be collected, managed, and disposed of in accordance with the sanitary waste management regulations and the permits for operation of the NTS 10c Industrial Waste Landfill (NDEP, 2006c).

Office trash and lunch waste will be placed in the dumpster to be transported to the sanitary landfill for disposal. Sanitary IDW generated at each CAS will only be collected in plastic bags, sealed, labeled with the CAS number from each site in which it was generated, and dated. The waste will then be placed in a roll-off box located in Mercury, or other approved roll-off box location. The number of bags of sanitary IDW placed in the roll-off box will be counted as they are placed in the roll-off box, noted in a log, and documented in the Field Activity Daily Log. These logs will provide necessary tracking information for ultimate disposal in the 10c Industrial Waste Landfill.

\subsubsection{Low-Level Radioactive Waste}

Radiological swipe surveys and/or direct-scan surveys may be conducted on reusable sampling equipment and the PPE and disposable sampling equipment waste streams exiting a radiologically controlled area (RCA). This allows for the immediate segregation of radioactive waste from waste that may be unrestricted regarding radiological release. Removable contamination limits, as defined in Table 4-2 of the current version of the NV/YMP RadCon Manual (NNSA/NSO, 2004), will be used to determine whether such waste may be declared unrestricted regarding radiological release versus being declared radioactive waste. Direct sampling of the waste may be conducted to aid in determining whether a particular waste unit (e.g., drum of soil) contains low-level radioactive waste, as necessary. Waste that is determined to be below the values of Table 4-2, by either direct radiological survey/swipe results or through process knowledge, will not be managed as potential radioactive waste but will be managed in accordance with the appropriate section of this document. Wastes in excess of Table 4-2 values will be managed as potential radioactive waste and in accordance with this section and other applicable sections of this document.

Low-level radioactive waste, if generated, will be managed in accordance with the contractor-specific waste certification program plan, DOE orders, and the requirements of the current version of the Nevada Test Site Waste Acceptance Criteria (NTSWAC) (NNSA/NSO, 2006c). Potential radioactive 
waste containers with soil, PPE, disposable sampling equipment, and/or rinsate may be staged at a designated radioactive material area (RMA), or RCA when full, or at the end of an investigation phase. The waste drums will remain at the RMA pending certification and disposal under NTSWAC requirements (NNSA/NSO, 2006c).

\subsubsection{Hazardous Waste}

The CAU will have waste accumulation areas established according to the needs of the project. Satellite accumulation areas (SAAs) and HWAAs will be managed consistent with the requirements of federal and state regulations (CFR, 2006a; NAC, 2006b). The HWAAs will be properly controlled for access, and will be equipped with spill kits and appropriate spill containment. Suspected hazardous wastes will be placed in DOT-compliant containers. All containerized hazardous waste will be handled, inspected, and managed in accordance with Title 40 Code of Federal Regulations (CFR) 265 Subpart I (CFR, 2006a). These provisions include managing the waste in containers compatible with the waste type and segregating incompatible waste types so that in the event of a spill, leak, or release, incompatible wastes shall not contact one another. The HWAAs will be covered under a Site-Specific Emergency Response and Contingency Action Plan until such time the waste is determined to be non-hazardous or all containers of hazardous waste have been removed from the storage area. Hazardous waste will be characterized in accordance with the requirement of Title 40 CFR 261 (CFR, 2006a). Resource Conservation and Recovery Act-“listed” waste has not been identified at CAU 234. Waste determined to be hazardous will be managed and transported in accordance with RCRA and DOT requirements to a permitted treatment, storage, and disposal facility (CFR, 2006a).

\subsubsection{Hydrocarbon Waste}

Hydrocarbon soil waste containing more than 100 milligrams per kilogram of TPH will be managed onsite in a drum or other appropriate container until fully characterized. Hydrocarbon waste may be disposed of at a designated hydrocarbon landfill (NDEP, 2006b), an appropriate hydrocarbon waste management facility (e.g., recycling facility), or other method in accordance with State of Nevada regulations. 


\subsubsection{Mixed Low-Level Waste}

If generated, MLLW shall be managed and dispositioned according to the requirements of RCRA (CFR, 2006a) or subject to agreements between NNSA/NSO and the State of Nevada, as well as DOE requirements for radioactive waste. The waste will be marked with the following: "Hazardous Waste Pending Analysis and Radioactive Waste Pending Analysis.” Until a waste determination has been completed and replaced with the appropriate radioactive/hazardous/DOT marking and labeling, waste characterized as MLLW will not be stored for a period of time that exceeds the requirements of RCRA unless subject to agreements between NNSA/NSO and the State of Nevada. The MLLW shall be transported via an approved hazardous waste/radioactive waste transporter to the NTS transuranic waste storage pad for storage pending treatment or disposal. The MLLW that meets the Land Disposal Restrictions treatment standards with hazardous waste constituents may be disposed of at the NTS Area 5 Radioactive Waste Management Site if the waste meets the requirements of the NTSWAC (NNSA/NSO, 2006c), the NTS NDEP permit for a Hazardous Waste Management Facility (NEV HW0009 [NDEP, 2000]), and the RCRA Part B Permit Application for Waste Management Activities at the Nevada Test Site (DOE/NV, 1999). Mixed waste constituent concentrations exceeding Land Disposal Restrictions will require development of a treatment and disposal plan under the requirements of the Mutual Consent Agreement between the DOE and State of Nevada (NDEP, 1995).

\subsubsection{Polychlorinated Biphenyls}

The management of polychlorinated biphenyls (PCBs) is governed by the Toxic Substances Control Act (USC, 1976) and its implementing regulations at 40 CFR 761 (CFR, 2006b). Polychlorinated biphenyl contamination may be found as a sole contaminant or in combination with any of the types of waste discussed in this document. For example, PCBs may be a co-contaminant in soil that contains a RCRA “characteristic” waste (PCB/hazardous waste), or in soil that contains radioactive wastes (PCB/radioactive waste), or even in mixed waste (PCB/radioactive/hazardous waste). The IDW will be initially evaluated using analytical results for media samples from the investigation. If any type of PCB waste is generated, it will be managed according to 40 CFR 761 (CFR, 2006b) as well as State of Nevada requirements (NAC, 2006a), guidance, and agreements with NNSA/NSO, and 40 CFR 261, as applicable. 


\subsection{Management of Specific Waste Streams}

\subsubsection{Personal Protective Equipment}

Personal protective equipment and disposable sampling equipment will be visually inspected for stains, discoloration, and gross contamination as the waste is generated, and also evaluated for radiological contamination. Staining and/discoloration will be assumed to be the result of contact with potentially contaminated media such as soil, sludge, or liquid. Gross contamination is the visible contamination of an item (e.g., clumps of soil/sludge on a sampling spoon or free liquid smeared on a glove). While gross contamination can often be removed through decontamination methods, removal of gross contamination from small items, such as gloves or booties is not typically conducted. Any IDW that meets this description will be segregated and managed as potentially "characteristic" hazardous waste. This segregated population of waste will be either: (1) assigned the characterization of the soil/sludge that was sampled, (2) sampled directly, or (3) undergo further evaluation using the soil/sludge sample results to determine how much soil/sludge would need to be present in the waste to exceed regulatory levels. Waste that is determined to be hazardous will be entered into an approved waste management system where it will be managed and dispositioned according to RCRA requirements or subject to agreements between NNSA/NSO and the State of Nevada. The PPE and equipment that is not visibly stained, discolored, or grossly contaminated and that is within the radiological free-release criteria will be managed as non-hazardous sanitary waste.

\subsubsection{Management of Decontamination Rinsate}

Rinsate at CAU 234 will not be considered hazardous waste unless there is evidence that the rinsate may display a RCRA characteristic. Evidence may include the presence of a visible sheen, $\mathrm{pH}$, or association with equipment/materials used to respond to a release/spill of a hazardous waste/substance. Decontamination rinsate that is potentially hazardous (using associated sample results and/or process knowledge) will be managed as characteristic hazardous waste (CFR, 2006a), pending analysis, as applicable. The regulatory status of the potentially hazardous rinsate will be determined through the application of associated sample results or through direct sampling. If the associated samples do not indicate the presence of hazardous constituents, then the rinsate will be characterized as non-hazardous. 
The disposal of non-hazardous rinsate will be consistent with guidance established in current NNSA/NSO Fluid Management Plans for the NTS as follows:

- Rinsate that is determined to be non-hazardous and contaminated and containing radioactive constituents at concentrations at or below the limits identified in the NTS Sewage Lagoon Permit (NDEP, 2005).

- Non-hazardous rinsate containing constituents at radioactive concentrations that exceed the limits identified in the NTS Sewage Lagoon Permit (NDEP, 2005), will be disposed of in an evaporation basin, with written approval from NDEP, or solidified and disposed of as sanitary low-level waste in accordance with the respective sections of this document.

\subsubsection{Management of Soil}

Waste streams consist of soil removed during excavation, drilling, site sampling or similar field activity that are not subsequently returned to the same approximate location.

This waste stream consists of soil removed for disposal during soil sampling, excavation, and/or drilling. This waste stream will be characterized based on laboratory analytical results from representative locations. If the soil is determined to potentially contain COCs, the material will either be managed onsite or containerized for transportation to an appropriate disposal site.

Onsite management of the waste soil will be allowed only if it is managed within an area of concern and it is appropriate to defer the management of the waste until the final remediation of the site. If this option is chosen, the waste soil shall be protected from run-on and run-off using appropriate protective measures based on the type of contaminant(s) (e.g., covered with plastic and bermed).

Management of soil waste for disposal consists of placing the waste in containers, labeling the containers, temporarily storing the containers until shipped, and shipping the waste to a storage/disposal site. The containers, labels, management of stored waste, transport to the disposal site, and disposal shall be appropriate for the type of waste (e.g., hazardous, hydrocarbon, mixed).

Note that soils returned into a borehole or excavation in the same approximate location from which it originated is not considered to be waste. 


\subsubsection{Management of Debris}

This waste stream can vary depending on site conditions. Debris that requires removal for the investigation activities (soil sampling, excavation, and/or drilling) must be characterized for proper management and disposition. Historical site process knowledge of waste generation field observations, field-monitoring/screening results, radiological survey/swipe results and/or the analytical results of samples either directly or indirectly associated with the waste may be used to characterize the debris. Debris will be inspected visually for stains, discoloration, and gross contamination. Debris may be deemed reusable, recyclable, sanitary waste, hazardous waste, PCB waste, or low-level waste. Waste that is not sanitary will be entered into an approved waste management system where it will be managed and dispositioned according to federal, state requirements, and agreements between NNSA/NSO and the State of Nevada. The debris will be managed onsite by berming and covering next to the excavation, by placement in a container(s), or left on the footprint of the CAS and its disposition deferred until implementation of corrective action at the site.

\subsubsection{Field-Screening Waste}

The use of field test kits and/or instruments may result in the generation of small quantities of hazardous wastes. If hazardous waste is produced by field screening, it will be segregated from other IDW and managed in accordance with the hazardous waste regulations (CFR, 2006a) and radiological release criteria, as applicable. For sites where field-screening samples contain radioactivity above background levels, field-screening methods that have the potential to generate hazardous waste will not be used, thus avoiding the potential to generate mixed waste. In the event a mixed waste is generated, the waste will be managed in accordance with Section 5.3.5. 


\subsection{Quality Assurance/Quality Control}

The overall objective of the characterization activities described in this CAIP is to collect accurate and defensible data to support the selection and implementation of a closure alternative for each CAU 234 CAS. Sections 6.1 and 6.2 discuss the collection of required QC samples in the field and QA requirements for laboratory/analytical data to achieve closure. Unless otherwise stated in this CAIP or required by the results of the DQO process (see Appendix A), this investigation will adhere to the Industrial Sites QAPP (NNSA/NV, 2002a).

\subsection{Quality Control Sampling Activities}

Field QC samples will be collected in accordance with established procedures. Field QC samples are collected and analyzed to aid in determining the validity of environmental sample results. The number of required QC samples depends on the types and number of environmental samples collected. The minimum frequency of collecting and analyzing QC samples for this investigation, as determined in the DQO process, include:

- $\quad$ Trip blanks (1 per sample cooler containing VOC environmental samples)

- Equipment rinsate blanks (1 per sampling event for each type of decontamination procedure)

- $\quad$ Source blanks (1 per lot of uncharacterized source material that contacts sampled media)

- Field duplicates (1 per 20 environmental samples or 1 per CAS per matrix, if less than 20 collected)

- $\quad$ Field blanks (1 per CAS)

- Laboratory QC samples (1 per 20 environmental samples or 1 per CAS per matrix, if less than 20 collected)

Additional QC samples may be submitted based on site conditions at the discretion of the Task Manager or Site Supervisor. Field QC samples shall be analyzed using the same analytical procedures implemented for associated environmental samples. Additional details regarding field QC samples are available in the Industrial Sites QAPP (NNSA/NV, 2002a). 


\subsection{Laboratory/Analytical Quality Assurance}

Criteria for the investigation, as stated in the DQOs (see Appendix A) and except where noted, require laboratory analytical quality data be used for making critical decisions. Rigorous QA/QC will be implemented for all laboratory samples including documentation, data verification and validation of analytical results, and an assessment of DQIs in relation to laboratory analysis.

\subsubsection{Data Validation}

Data verification and validation will be performed in accordance with the Industrial Sites QAPP (NNSA/NV, 2002a), except where otherwise stipulated in this CAIP. All chemical and radiological laboratory data from samples that are collected and analyzed will be evaluated for data quality according to company-specific procedures. The data will be reviewed to ensure that all suspected samples were appropriately collected, analyzed, and the results passed data validation criteria. Validated data, including estimated data (i.e., J-qualified), will be assessed to determine whether the data meet the DQO investigation requirements and the performance criteria for the DQIs. The results of this assessment will be documented in the Corrective Action Decision Document (CADD). If the DQOs were not met, corrective actions will be evaluated, selected, and implemented (e.g., refine CSM or resample to fill data gaps).

\subsubsection{Data Quality Indicators}

The DQIs are qualitative and quantitative descriptors used in interpreting the degree of acceptability or utility of data. Data quality indicators are used to evaluate the entire measurement system and laboratory measurement processes (i.e., analytical method performance) as well as to evaluate individual analytical results (i.e., parameter performance). The quality and usability of data used to make DQO decisions will be assessed based on the following DQIs:

- Precision

- Accuracy/bias

- Representativeness

- Comparability

- Completeness

- Sensitivity 
Table 6-1 provides the established analytical method/measurement system performance criteria for each of the DQIs and the potential impacts to the decision if the criteria are not met. The following subsections discuss each of the DQIs that will be used to assess the quality of laboratory data. Due to changes in analytical methodology and changes in analytical laboratory contracts, criteria for precision and accuracy in Tables 3-3 and 3-4 that vary from corresponding information in the QAPP will supersede that information in the QAPP (NNSA/NV, 2002a).

\subsubsection{Precision}

Precision is a measure of the repeatability of the analysis process from sample collection through analysis results. It is used to assess the variability between two equal samples.

Determinations of precision will be made for field duplicate samples and laboratory duplicate samples. Field duplicate samples will be collected simultaneously with samples from the same source under similar conditions in separate containers. The duplicate sample will be treated independently of the original sample to assess field impacts and laboratory performance on precision through a comparison of results. Laboratory precision is evaluated as part of the required laboratory internal QC program to assess performance of analytical procedures. The laboratory sample duplicates are an aliquot, or subset, of a field sample generated in the laboratory. They are not a separate sample but a split, or portion, of an existing sample. Typically, laboratory duplicate QC samples may include matrix spike duplicate and laboratory control sample (LCS) duplicate samples for organic, inorganic, and radiological analyses.

Precision is a quantitative measure used to assess overall analytical method and field-sampling performance as well as to assess the need to "flag” (qualify) individual parameter results when corresponding QC sample results are not within established control limits.

The criteria used for the assessment of inorganic chemical precision when both results are greater than or equal to $5 x$ reporting limit (RL) is 20 percent and 35 percent for aqueous and soil samples, respectively. When either result is less than 5x RL, a control limit of $\pm 1 x R L$ and $\pm 2 x$ RL for aqueous and soil samples, respectively, is applied to the absolute difference. 
Table 6-1

Laboratory and Analytical Performance Criteria for CAU 234 Data Quality Indicators

\begin{tabular}{|c|c|c|}
\hline $\begin{array}{l}\text { Data Quality } \\
\text { Indicator }\end{array}$ & Performance Metric & $\begin{array}{l}\text { Potential Impact on Decision } \\
\text { If Performance Metric Not Met }\end{array}$ \\
\hline Precision & $\begin{array}{l}\text { At least } 80 \% \text { of the sample results for each } \\
\text { measured contaminant are not qualified for } \\
\text { precision based on the criteria for each } \\
\text { analytical method-specific and } \\
\text { laboratory-specific criteria presented in } \\
\text { Section } 6.2 .3 \text {. }\end{array}$ & $\begin{array}{l}\text { If the performance metric is not met, the } \\
\text { affected analytical results from each } \\
\text { affected CAS will be assessed to } \\
\text { determine whether there is sufficient } \\
\text { confidence in analytical results to use the } \\
\text { data in making DQO decisions. }\end{array}$ \\
\hline Accuracy & $\begin{array}{l}\text { At least } 80 \% \text { of the sample results for each } \\
\text { measured contaminant are not qualified for } \\
\text { accuracy based on the method-specific and } \\
\text { laboratory-specific criteria presented in } \\
\text { Section } 6.2 .4 \text {. }\end{array}$ & $\begin{array}{l}\text { If the performance metric is not met, the } \\
\text { affected analytical results from each } \\
\text { affected CAS will be assessed to } \\
\text { determine whether there is sufficient } \\
\text { confidence in analytical results to use the } \\
\text { data in making DQO decisions. }\end{array}$ \\
\hline Sensitivity & $\begin{array}{l}\text { Minimum detectable concentrations are less } \\
\text { than or equal to respective FALs. }\end{array}$ & $\begin{array}{l}\text { Cannot determine whether COCs are } \\
\text { present or migrating at levels of concern. }\end{array}$ \\
\hline Comparability & $\begin{array}{l}\text { Sampling, handling, preparation, analysis, } \\
\text { reporting, and data validation are performed } \\
\text { using standard methods and procedures. }\end{array}$ & $\begin{array}{c}\text { Inability to combine data with data } \\
\text { obtained from other sources and/or } \\
\text { inability to compare data to regulatory } \\
\text { action levels. }\end{array}$ \\
\hline Representativeness & $\begin{array}{l}\text { Samples contain contaminants at } \\
\text { concentrations present in the environmental } \\
\text { media from which they were collected. }\end{array}$ & $\begin{array}{l}\text { Analytical results will not represent true } \\
\text { site conditions. Inability to make } \\
\text { appropriate DQO decisions. }\end{array}$ \\
\hline Completeness & $\begin{array}{c}80 \% \text { of the CAS-specific COPCs } \\
\text { have valid results. } \\
100 \% \text { of CAS-specific targeted contaminants } \\
\text { have valid results. }\end{array}$ & $\begin{array}{l}\text { Cannot support/defend decision on } \\
\text { whether COCs are present. }\end{array}$ \\
\hline Extent Completeness & $\begin{array}{l}100 \% \text { of COCs used to define extent } \\
\text { have valid results. }\end{array}$ & $\begin{array}{l}\text { Extent of contamination cannot be } \\
\text { accurately determined. }\end{array}$ \\
\hline $\begin{array}{l}\text { Clean Closure } \\
\text { Completeness }\end{array}$ & $\begin{array}{c}100 \% \text { of targeted contaminants } \\
\text { have valid results. }\end{array}$ & $\begin{array}{l}\text { Cannot determine whether } \\
\text { COCs remain in soil. }\end{array}$ \\
\hline
\end{tabular}

CAS $=$ Corrective action site

$\mathrm{COC}=$ Contaminant of concern

$\mathrm{COPC}=$ Contaminant of potential concern

$\mathrm{DQO}=$ Data quality objective

$\mathrm{FAL}=$ Final action level 
The criteria used for the assessment of radiological precision when both results are greater than or equal to 5x MDC is 20 percent and 35 percent for aqueous and soil samples, respectively. When either result is less than 5x MDC, the normalized difference should be between -2 and +2 for aqueous and soil samples. The parameters to be used for assessment of precision for duplicates are listed in Table 3-4.

Values outside the specified criteria do not necessarily result in the qualification of analytical data. It is only one factor in making an overall judgment about the quality of the reported analytical results. The performance metric for assessing the DQI of precision on DQO decisions (see Table 6-1) is that at least 80 percent of sample results for each measured contaminant are not qualified due to duplicates exceeding the criteria. If this performance is not met, an assessment will be conducted in the investigation report on the impacts to DQO decisions specific to affected contaminants and CASs.

The criteria used for the assessment of organic chemical precision is based on professional judgement using laboratory-derived control limits and gas chromatography comparison.

\subsubsection{Accuracy}

Accuracy is a measure of the closeness of an individual measurement to the true value. It is used to assess the performance of laboratory measurement processes.

Accuracy is determined by analyzing a reference material of known parameter concentration or by reanalyzing a sample to which a material of known concentration or amount of parameter has been added (spiked). Accuracy will be evaluated based on results from three types of spiked samples: matrix spike (MS), LCS, and surrogates (organics). The LCS sample is analyzed with the field samples using the same sample preparation, reagents, and analytical methods employed for the samples. One LCS will be prepared with each batch of samples for analysis by a specific measurement.

The criteria used for the assessment of inorganic chemical accuracy are 75 to 125 percent for MS recoveries and 80 to 120 percent for LCS recoveries. For organic chemical accuracy, MS and LCS laboratory-specific percent recovery criteria developed and generated in-house by the laboratory 
according to approved laboratory procedures are applied. The criteria used for the assessment of radiochemical accuracy are 80 to 120 percent for LCS and MS recoveries.

Values outside the specified criteria do not necessarily result in the qualification of analytical data. It is only one factor in making an overall judgment about the quality of the reported analytical results. Factors beyond laboratory control, such as sample matrix effects, can cause the measured values to be outside of the established criteria. Therefore, the entire sampling and analytical process may be evaluated when determining the usability of the affected data.

The performance metric for assessing the DQI of accuracy on DQO decisions (see Table 6-1) is that at least 80 percent of the sample results for each measured contaminant are not qualified for accuracy. If this performance is not met, an assessment will be conducted in the investigation report on the impacts to DQO decisions specific to affected contaminants and CASs.

\subsubsection{Representativeness}

Representativeness is the degree to which sample characteristics accurately and precisely represent a characteristics of a population or an environmental condition (EPA, 2002). Representativeness is assured by a carefully developing the sampling strategy during the DQO process such that false negative and false positive decision errors are minimized. The criteria listed in DQO Step 6 - Specify the Tolerable Limits on Decision Errors are:

- For Decision I judgmental sampling, having a high degree of confidence that the sample locations selected will identify COCs if present anywhere within the CAS.

- For Decision I probabilistic sampling, having a high degree of confidence that the sample locations selected will represent contamination of the CAS.

- Having a high degree of confidence that analyses conducted will be sufficient to detect any COCs present in the samples.

- For Decision II, having a high degree of confidence that the sample locations selected will identify the extent of COCs.

These are qualitative measures that will be used to assess measurement system performance for representativeness. The assessment of this qualitative criterion will be presented in the investigation report. 


\subsubsection{Completeness}

Completeness is defined as generating sufficient data of the appropriate quality to satisfy the data needs identified in the DQOs. For judgmental sampling, completeness will be evaluated using a quantitative measure and a qualitative assessment. The quantitative measurement to be used to evaluate completeness is presented in Table 6-1 and is based on the percentage of measurements that are judged to be valid.

For the judgmental sampling approach, the completeness goal for targeted contaminants and the remaining COPCs is 100 and 80 percent, respectively. If this goal is not achieved, the dataset will be assessed for potential impacts on making DQO decisions.

The qualitative assessment of completeness is an evaluation of the sufficiency of information available to make DQO decisions. This assessment will be based on meeting the data needs identified in the DQOs and will be presented in the investigation report. Additional samples will be collected if it is determined that the number of samples do not meet completeness criteria.

\subsubsection{Comparability}

Comparability is a qualitative parameter expressing the confidence with which one dataset can be compared to another (EPA, 2002). The criteria for the evaluation of comparability will be that all sampling, handling, preparation, analysis, reporting, and data validation were performed and documented in accordance with approved procedures that are in conformance with standard industry practices. Analytical methods and procedures approved by DOE will be used to analyze, report, and validate the data. These methods and procedures are in conformance with applicable methods used in industry and government practices. An evaluation of comparability will be presented in the investigation report. 


\subsubsection{Sensitivity}

Sensitivity is the capability of a method or instrument to discriminate between measurement responses representing different levels of the variable of interest (EPA, 2002). The evaluation criteria for this parameter will be that measurement sensitivity (detection limits) will be less than or equal to the corresponding FALs. If this criterion is not achieved, the affected data will be assessed for usability and potential impacts on meeting site characterization objectives. This assessment will be presented in the investigation report. 


\subsection{Duration and Records Availability}

\subsection{Duration}

Table 7-1 is a tentative duration of activities (in calendar days) for the CAI.

Table 7-1

Corrective Action Investigation Activity Durations

\begin{tabular}{|c|c|}
\hline $\begin{array}{c}\text { Duration } \\
\text { (days) }\end{array}$ & Activity \\
\hline \hline 5 & Site Preparation \\
\hline 76 & Fieldwork Preparation and Mobilization \\
\hline 15 & Sampling \\
\hline 160 & Data Assessment \\
\hline 180 & Waste Management \\
\hline
\end{tabular}

\subsection{Records Availability}

Historic information and documents referenced in this plan are retained in the NNSA/NSO project files in Las Vegas, Nevada, and can be obtained through written request to the NNSA/NSO Federal Sub-Project Director. This document is available in the DOE public reading rooms located in Las Vegas and Carson City, Nevada, or by contacting the DOE Federal Sub-Project Director. The NDEP maintains the official Administrative Record for all activities conducted under the auspices of the FFACO. 


\subsection{References}

ARL/SORD, see Air Resources Laboratory/Special Operations and Research Division.

ASTM, see American Society for Testing and Materials.

Air Resources Laboratory/Special Operations and Research Division. 2007. NTS Climatological Rain Gauge Data. As accessed at http://www.sord.nv.doe/home_climate_rain.htm on 13 April.

American Society for Testing and Materials. 1995. Standard Guide for Risk-Based Corrective Action Applied at Petroleum Release Sites, ASTM E 1739-95 (Reapproved 2002). Philadelphia, PA.

BN, see Bechtel Nevada.

Bechtel Nevada. 1999. Nevada Test Site Performance Objective for Certification of Nonradioactive Hazardous Waste, Rev. 0, G-E11/96.01. Las Vegas, NV.

CFR, see Code of Federal Regulations.

Code of Federal Regulations. 2006a. Title 40 CFR, Parts 260-282, "Hazardous Waste Management System: General.” Washington, DC: U.S. Government Printing Office.

Code of Federal Regulations. 2006b. Title 40 CFR, Parts 761, "Polychlorinated Biphenyls (PCBs) Manufacturing, Processing, Distribution in Commerce, and Use Prohibitions.” Washington, DC: U.S. Government Printing Office.

Code of Federal Regulations. 2006c. Title 40 CFR, Part 763, “Asbestos.” Washington, DC:

U.S. Government Printing Office.

DOE, see U.S. Department of Energy.

DOE/NV, see U.S. Department of Energy, Nevada Operations Office.

DRI, see Desert Research Institute.

Desert Research Institute. 1988. CERCLA Preliminary Assessment of DOE's Nevada Operations Office, Nuclear Weapons Testing Areas. April. Las Vegas, NV.

EPA, see U.S. Environmental Protection Agency.

ERDA, see U.S. Energy Research and Development Administration. 
FFACO, see Federal Facility Agreement and Consent Order.

Federal Facility Agreement and Consent Order. 1996 (as amended). Agreed to by the State of Nevada; U.S. Department of Energy, Environmental Management; U.S. Department of Defense; and U.S. Department of Energy, Legacy Management.

Laczniak, R.J., J.C. Cole, D.A. Sawyer, and D.A. Trudeau. 1996. Summary of Hydrogeologic Controls Ground-Water flow at the Nevada Test Site, Nye County, Nevada. As accessed at http://water.usgs.geo/pubs/wri/wri964109/report.htm on 13 April 2007.

Moore, J., Science Applications International Corporation. 1999. Memorandum to M. Todd (SAIC) entitled, "Background Concentrations for NTS and TTR Soil Samples,” 3 February. Las Vegas, NV: IT Corporation.

Murphy, T., Bureau of Federal Facilities. 2004. Letter to R. Bangerter (NNSA/NSO) entitled, "Review of Industrial Sites Project Document Guidance for Calculating Industrial Sites Project Remediation Goals for Radionuclides in Soil Using the Residual Radiation (RESRAD) Computer Code.” 19 November. Las Vegas, NV.

NAC, see Nevada Administrative Code.

NBMG, see Nevada Bureau of Mines and Geology.

NCRP, see National Council on Radiation Protection and Measurements.

NDEP, see Nevada Division of Environmental Protection.

NNSA/NSO, see U.S. Department of Energy, National Nuclear Security Administration Nevada Site Office.

NNSA/NV, see U.S. Department of Energy, National Nuclear Security Administration Nevada Operations Office.

NOAA, see National Oceanic and Atmospheric Administration.

NRS, see Nevada Revised Statutes.

National Council on Radiation Protection and Measurements. 1999. Recommended Screening Limits for Contaminated Surface Soil and Review of Factors Relevant to Site-Specific Studies/National Council on Radiation Protection and Measurements, NCRP Report No. 129. Bethesda, MD.

National Oceanic and Atmospheric Administration. 2002. Precipitation Summary. As accessed at http://www.sord.nv.doe.gov/home_climate.htm on 13 April 2007. 
Nevada Administrative Code. 2006a. NAC 444, "Sanitation.” Carson City, NV. As accessed at http://www.leg.state.nv.us/nac on 13 April 2007.

Nevada Administrative Code. 2006b. NAC 445A, "Water Controls.” Carson City, NV. As accessed at http://www.leg.state.nv.us/nac on 13 April 2007.

Nevada Administrative Code. 2006c. NAC 445A.227, “Contamination of Soil: Order by Director for Corrective Action; Factors To Be Considered in Determining Whether Corrective Action Required.” Carson City, NV. As accessed at http://www.leg.state.nv.us/nac on 13 April 2007.

Nevada Administrative Code. 2006d. NAC 445A.22705, “Contamination of Soil: Evaluation of Site by Owner or Operator; Review of Evaluation by Division.” Carson City, NV. As accessed at http://www.leg.state.nv.us/nac on 13 April 2007.

Nevada Administrative Code. 2006e. NAC 445A.2272, "Contamination of Soil: Establishment of Action Levels.” Carson City, NV. As accessed at http://www.leg.state.nv.us/nac on 13 April 2007.

Nevada Bureau of Mines and Geology. 1998. Mineral and Energy Resource Assessment of the Nellis Air Force Range, Open-File Report 98-1. Reno, NV.

Nevada Division of Environmental Protection. 1995. Mutual Consent Agreement between the State of Nevada and the U.S. Department of Energy for the Storage of Low-Level Land Disposal Restricted Mixed Waste. Carson City, NV.

Nevada Division of Environmental Protection. 2000. Hazardous Waste Management Facility Draft Permit, No. NEVHW0009. Carson City, NV.

Nevada Division of Environmental Protection. 2005. State of Nevada Water Pollution Control General Permit, No. GNEV93001. Carson City, NV.

Nevada Division of Environmental Protection. 2006a. Class II Solid Waste Disposal Site for Municipal and Solid Waste, Area 23 of the NTS, Permit SW 13-097-04. Carson City, NV.

Nevada Division of Environmental Protection. 2006b (as amended in August 2000). Class III Solid Waste Disposal Site for Hydrocarbon Burdened Soils, Area 6 of the NTS, Permit SW 1309702. Carson City, NV.

Nevada Division of Environmental Protection. 2006c. Class III Solid Waste Disposal Site; U1OC, Area 9 of the NTS, Permit SW 13-097-03. Carson City, NV.

Nevada Revised Statutes. 2005a. NRS 444.440 - 444.620, “Collection and Disposal of Solid Waste.” Carson City, NV. 
Nevada Revised Statutes. 2005b. NRS 459.400 - 459.600, “Disposal of Hazardous Waste.” Carson City, NV.

Nevada Revised Statutes. 2005c. NRS 618.750 - 618.840, “Disposal of Hazardous Waste.” Carson City, NV.

Professional Analysis, Inc. 1992. Compilation of Data on Radionuclide Migration: Aleman Site, Nevada Test Site, Nye County, Nevada. 10 November. Las Vegas, NV.

SNJV, see Stoller-Navarro Joint Venture.

SNJV GIS Systems, see Stoller-Navarro Joint Venture Geographic Information Systems.

Shott, G.J., V. Yucel, M.J. Sully, L.E. Barker, S.E. Rawlinson, and B.A. Moore. 1997. Performance Assessment/Composite Analysis for the Area 3 Radioactive Waste Management Site at the Nevada Test Site, Nye County, Nevada, Rev. 2.0. Las Vegas, NV.

Stoller-Navarro Joint Venture. 2006. Radiological Land Area Survey, CAU 234 - Mud Pits, Cellars, Mud Spills, CAS 02-09-48 - Mud Spill at the Nevada Test Site. Las Vegas, NV.

Stoller-Navarro Joint Venture Geographic Information Systems. 2007. ESRI Arc GIS Software.

USC, see United States Code.

USGS, see U.S. Geological Survey.

USGS and DOE, see United States Geological Survey and U.S. Department of Energy.

United States Code. 1976. 15 USC 2601 et seq., “Toxic Substances Control Act.” Enacted by Public Law No. 94-469, as amended. Washington, DC: U.S. Government Printing Office.

U.S. Department of Energy. 1993. Radiation Protection of the Public and the Environment, DOE Order 5400.5, Change 2. Washington, DC: U.S. Government Printing Office.

U.S. Department of Energy. 1997a. Evaluation of Radiochemical Data Usability, ES/ER/MS-5. April. Prepared by J.G. Paar and D.R. Porterfield. Oak Ridge, TN: U.S. Department of Energy.

U.S. Department of Energy. 1997b. The Procedures Manual of the Environmental Measurements Laboratory, HASL-300, 28th Ed., Vol. I. New York, NY.

U.S. Department of Energy, National Nuclear Security Administration Nevada Operations Office. 2002a. Industrial Sites Quality Assurance Project Plan, Nevada Test Site, Nevada, Rev. 3, DOE/NV--372. Las Vegas, NV. 
U.S. Department of Energy, National Nuclear Security Administration Nevada Operations Office. 2002b. Underground Test Area Project Waste Management Plan, Rev. 2, DOE/NV--343. Las Vegas, NV.

U.S. Department of Energy, National Nuclear Security Administration Nevada Site Office. 2004. NV/YMP Radiological Control Manual, Rev. 5, DOE/NV/11718-079, UC-702. Prepared by A.L. Gile of Bechtel Nevada. Las Vegas, NV.

U.S. Department of Energy, National Nuclear Security Administration Nevada Site Office. 2006a. Closure Report for Corrective Action Units 530, 531, 532, 533, 534, 535: NTS Mud Pits, Nevada Test Site, Nevada, Rev. 0, DOE/NV--1131. Las Vegas, NV.

U.S. Department of Energy, National Nuclear Security Administration Nevada Site Office. 2006b. Industrial Sites Project Establishment of Final Action Levels, Rev. 0, DOE/NV--1107. Las Vegas, NV.

U.S. Department of Energy, National Nuclear Security Administration Nevada Site Office. 2006c. Nevada Test Site Waste Acceptance Criteria, Rev. 6-02, DOE/NV--325. Las Vegas, NV.

U.S. Department of Energy, Nevada Operations Office. 1992. Remedial Investigation and Feasibility Study for the Plutonium Contaminated Soils at Nevada Test Site, Nellis Air Force Range and Tonopah Test Range, April. Las Vegas, NV.

U.S. Department of Energy, Nevada Operations Office. 1996. Final Environmental Impact Statement for the Nevada Test Site and Off-Site Locations in the State of Nevada, DOE/EIS 0243. Las Vegas, NV.

U.S. Department of Energy, Nevada Operations Office. 1997. Integrated Safety Management Policy, DOE Order NV P 450.4. Las Vegas, NV.

U.S. Department of Energy, Nevada Operations Office. 1998. Nevada Test Site Resource Management Plan. DOE/NV--518, Las Vegas, NV.

U.S. Department of Energy, Nevada Operations Office. 1999. RCRA Part B Permit (NEV HW0021) Application for Waste Management Activities at the Nevada Test Site. Las Vegas, NV.

U.S. Energy Research and Development Administration. 1977. Final Environmental Impact Statement, Nevada Test Site, Nye County, Nevada, ERDA-1551, Washington, DC.

U.S. Environmental Protection Agency. 1980. Prescribed Procedures for Measurement of Radioactivity in Drinking Water, EPA 600/4-80-032.

U.S. Environmental Protection Agency. 1996. Test Method for Evaluating Solid Waste Physical/Chemical Methods, SW-846, 3rd Edition. Washington, DC. 
U.S. Environmental Protection Agency. 2002. Guidance for Quality Assurance Project Plans, EPA QA/G5. Washington, DC.

U.S. Environmental Protection Agency. 2004a. Region 9 Preliminary Remediation Goals (PRGs). As accessed at http://www.epa.gov/region09/waste/sfund/prg/index.htm on 13 April 2007. Prepared by S.J. Smucker. San Francisco, CA.

U.S. Environmental Protection Agency. 2004b. Contract Laboratory Program Statement of Work for Inorganic Analysis, ILMO 4.0, EPA/540/R-95/121. Washington, DC.

U.S. Geological Survey. 1990. Geologic Map of the Nevada Test Site, Southern Nevada, USGS Map I-2046. Denver, CO.

U.S. Geological Survey. 1996. Summary of Hydrogeological Controls on Groundwater Flow at the Nevada Test Site, Nye County, Nevada, USGS Water Resources Investigations Report 96-4109. Prepared by R.J. Laczniak, J.C. Cole, D.A. Sawyer, and D.A. Trudeau.

U.S. Geological Survey. 2006. “Ground-Water Levels for Nevada.” As accessed at http://nwis.waterdata.usgs.gov/nv/nwis/gwlevels on 13 April 2007.

U.S. Geological Survey and U.S. Department of Energy. 2006. "USGS/DOE Cooperative Studies in Nevada” As accessed at Appendix J CAU 234, CAS 12-30-14 J-32, http://nevada.usgs.gov/doe\%5Fnv/sitepage_temp.cfm?site_id=370837116040901 as accessed on 10 August. 


\section{Appendix A}

\section{Data Quality Objectives}




\section{A.1.0 Introduction}

The DQO process described in this appendix is a seven-step strategic, systematic method used to plan data collection activities and define performance criteria for the CAU 234, Mud Pits, Cellars, and Mud Spills field investigation. The DQOs are designed to ensure that the data collected will provide sufficient and reliable information to identify, evaluate, and technically defend recommended corrective actions (i.e., no further action, closure in place, or clean closure). Existing information about the nature and extent of contamination at the CASs in CAU 234 is insufficient to evaluate and select preferred corrective actions; therefore, a CAI will be conducted.

The CAU 234 investigation will be based on the DQOs presented in this appendix as developed by representatives of the NDEP and the NNSA/NSO. The seven steps of the DQO process presented in Sections A.3.0 through A.9.0 were developed in accordance with EPA Guidance on Systematic Planning Using the Data Quality Objectives Process (EPA, 2006).

The DQO process presents a judgmental sampling approach. In general, the procedures used in the DQO process provide:

- A method to establish performance or acceptance criteria, which serve as the basis for designing a plan for collecting data of sufficient quality and quantity to support the goals of a study.

- Criteria that will be used to establish the final data collection design such as:

- The nature of the problem that has initiated the study and a conceptual model of the environmental hazard to be investigated.

- The decisions or estimates that need to be made and the order of priority for resolving them.

- The type of data needed.

- An analytic approach or decision rule that defines the logic for how the data will be used to draw conclusions from the study findings. 
- Acceptable quantitative criteria on the quality and quantity of the data to be collected, relative to the ultimate data use.

- A data collection design that will generate data meeting the quantitative and qualitative criteria specified. A data collection design specifies the type, number, location, and physical quantity of samples and data, as well as the QA and QC activities that will ensure that sampling design and measurement errors are managed sufficiently to meet the performance or acceptance criteria specified in the DQOs. 


\section{A.2.0 Background Information}

The following 12 CASs that comprise CAU 234 are located in Areas 2, 3, 4, 12, and 15 of the NTS, as shown in Figure A.2-1:

- $\quad$ CAS 02-09-48, Area 2 Mud Plant \#1

- CAS 02-09-49, Area 2 Mud Plant \#2

- CAS 02-99-05, Mud Spill

- CAS 03-09-02, Mud Dump Trenches

- CAS 04-44-02, Mud Spill

- CAS 04-99-02, Mud Spill

- CAS 12-09-01, Mud Pit

- CAS 12-09-04, Mud Pit

- CAS 12-09-08, Mud Pit

- CAS 12-30-14, Cellar

- CAS 12-99-07, Mud Dump

- CAS 15-09-01, Mud Pit

The following sections (Sections A.2.2 through A.2.13) provide a CAS description, physical setting and operational history, release information, and previous investigation results for each CAU 234 CAS. The CAS-specific COPCs are provided in the following sections. Many of the COPCs are based on a conservative evaluation of possible site activities considering the incomplete site histories of the CASs and considering contaminants found at similar NTS sites. Targeted contaminants are defined as those contaminants that are known or that could be reasonably suspected to be present within the CAS based on previous sampling or process knowledge.

\section{A.2.1 Categorization of Corrective Action Sites in CAU 234}

The mud pit and mud spill CASs in CAU 234 are very similar to the CASs investigated in the Closure Report for Corrective Action Units 530, 531, 532, 533, 534, 535: NTS Mud Pits (NNSA/NSO, 2006a). The Mud Pit CR demonstrated that TPH-DRO is not a COC at NTS mud pit CASs (no other contaminants were identified in the Mud Pit CR) and provided the following recommendation: 


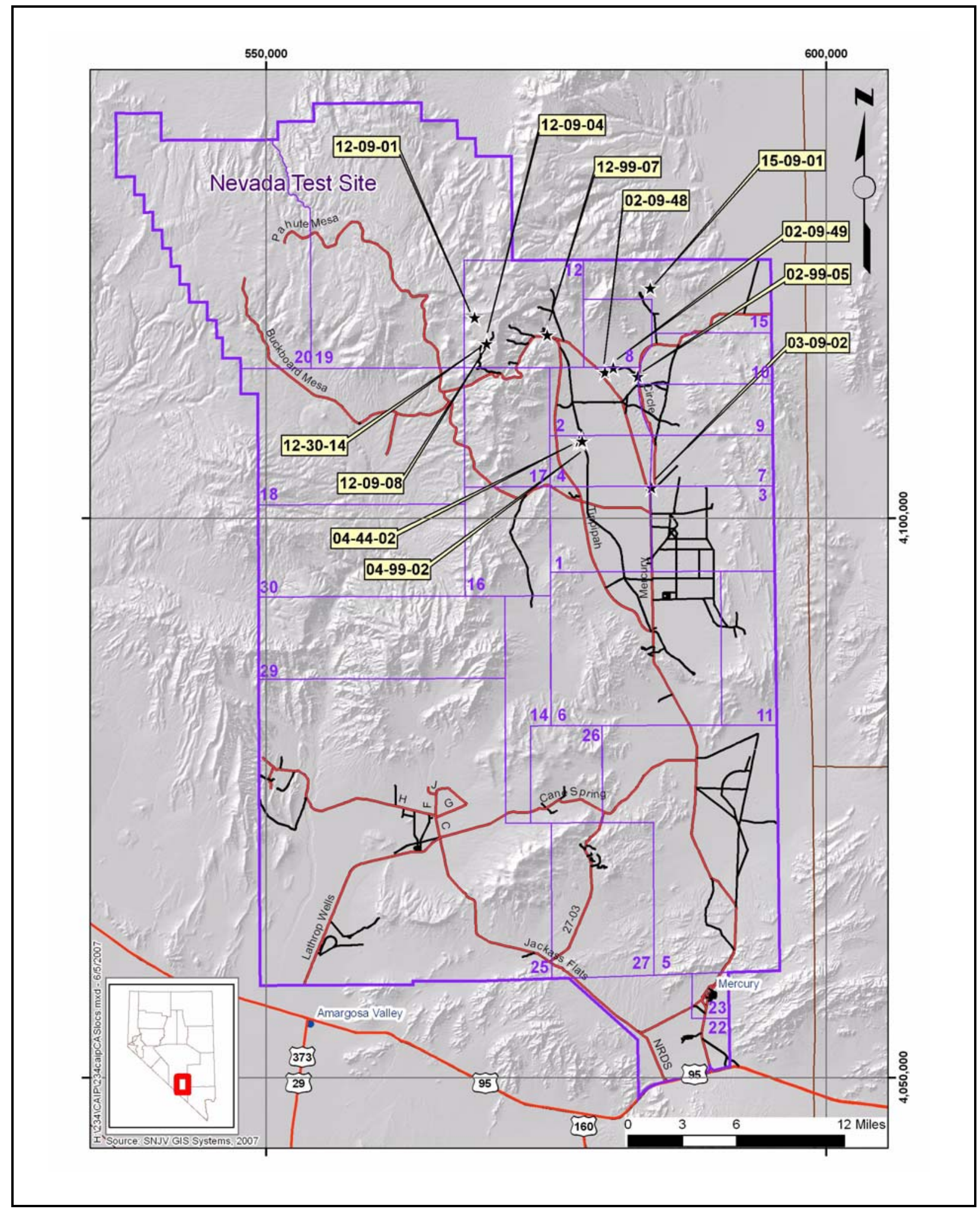

Figure A.2-1

Nevada Test Site Map with CAU 234 CAS Locations 
"Therefore, consistent with the conclusions and recommendations in the Mud Pit CR and SAFER Plan, non-radioactive mud pit CASs identified in the future should be transferred directly from Appendix II to Appendix IV of the FFACO, provided they meet the following criteria:

- The CAS is either a single mud pit or a system of mud pits.

- The CAS is not located in a radiological or radioactive material posted area.

- The CAS does not serve as habitat for threatened and endangered species.

- There are no biasing factors evident based on a visual inspection.”

The CAU 234 mud pit or mud spill CASs that meet these criteria will not require that additional samples be collected. Also, CASs that contain only unused drilling mud or concrete will not require sampling, because there are no identified potential releases of hazardous waste associated with unused drilling mud or concrete. As an aid in the identification of which CAU 234 CASs do not require additional sample collection, the CASs have been categorized as follows:

- Category I CASs are those in which the mud pits or mud spills fit the Mud Pit CR criteria and will be recommended for closure with no further investigation.

- Category II CASs are those in which the mud pits or mud spills are comprised only of unused drilling mud or concrete where there are no indicators of a potential to release. These CASs do not fit the Mud Pit CR criteria, because unused drilling muds were not included in the investigation. However, as the drilling muds were not used for field operations, they possess no potential for release of contaminants.

- Category III CASs do not meet the criteria of the Mud Pit CR, because they contain a potential release that was not addressed by the Mud Pit CR.

Each CAS will be classified by Category I, II, or III according to Table A.2-1. Only Category III CASs will require that additional samples be collected. Therefore, DQOs will be developed only for those CASs identified as Category III. Justification for categorization of each CAS is in Section 2.6. 
Table A.2-1

Corrective Action Site Categorization for CAU 234

\begin{tabular}{|c||c|c|c|}
\cline { 2 - 4 } \multicolumn{1}{c|}{} & \multicolumn{2}{c|}{ CAS Category } \\
\cline { 2 - 4 } \multicolumn{1}{c|}{} & I & II \\
\hline \multirow{2}{*}{ CAS Number } & $\begin{array}{c}04-44-02,04-99-02, \\
12-09-04,15-09-01\end{array}$ & $\begin{array}{c}02-09-49,02-99-05, \\
12-99-07\end{array}$ & $\begin{array}{c}02-09-48,03-09-02,09-01,12-09-08, \\
12-30-14\end{array}$ \\
\hline
\end{tabular}

\section{A.2.2 Corrective Action Site 02-09-48, Area 2 Mud Plant \#1}

Corrective Action Site 02-09-48 consists of unused mud in a concrete, 10,000 barrel capacity storage sump adjacent to the former Area 2 mud plant located southeast of the 2-07 Road in Area 2 of the NTS. The sump is approximately 154 by $77 \mathrm{ft}$ and approximately $15 \mathrm{ft}$ deep with an overhead catwalk and piping running the length of the sump. Tumbleweeds are scattered throughout the sump. A sign at the east end of the catwalk reads "Caution Asbestos,” referring to insulation covering a section of the piping at the east end of the sump. There is a metal drum and an aerator in the northeast portion of the sump. Figure A.2-2 shows a photograph of the CAS, which meets the criteria for Category III as defined in Section A.2.1, due to the presence of the potential to release associated with the drum located within the mud sump.

Physical Setting and Operational History - Corrective Action Site 02-09-48 is located in Area 2 of the NTS, adjacent to the Area 2 Mud Plant. The mud sump contained manufactured drilling mud for use in NTS drilling operations. The site is currently inactive and abandoned.

Release Information - The source of potential contamination is the mud located within the mud storage sump, and any potential material located within the rusted metal drum or in the mud in contact with the drum. Because it is believed that the mud in the mud storage sump is unused, there is no reason to believe that the mud contains potential contaminants associated with drilling operations. Application of the guidelines identified in the Mud Pit CR for CAUs 530 - 535, mud pits and spills that have no other recognizable environmental condition (e.g., staining), other than their common-place use as drilling mud, may be exempt from further investigation (NNSA/NSO, 2006a). Therefore, there is no potential for release of contaminants from the mud located in the mud storage sump at this CAS. The presence of the rusted metal drum within the mud pit poses a potential for release of contaminants to the mud storage sump. 


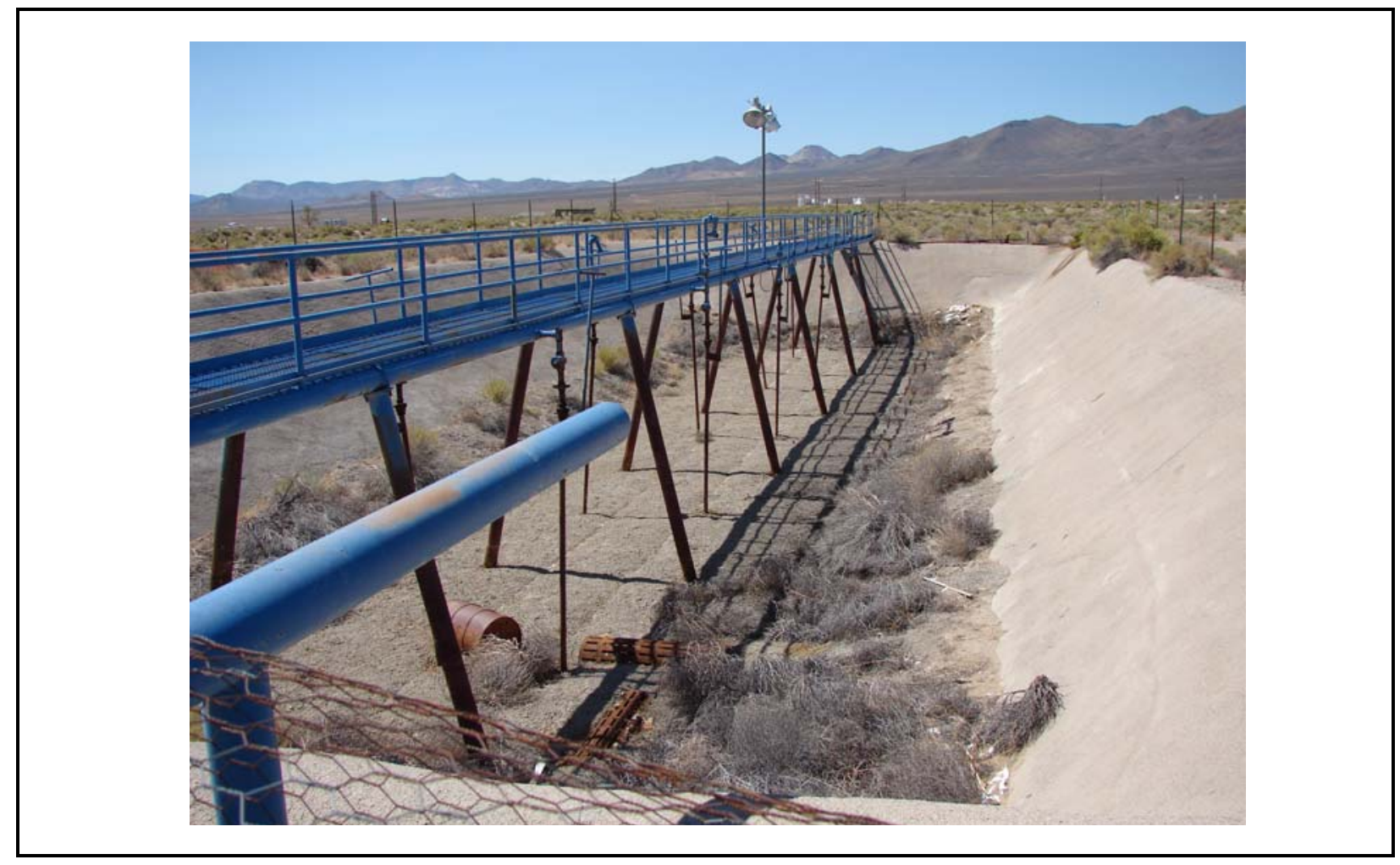

Figure A.2-2

Corrective Action Site 02-09-48, Area 2 Mud Plant \#1

Previous Investigation Results - Based on records review, no sampling has been conducted at this CAS. On May 23, 2006, a radiological survey was conducted at CAS 02-09-48. The survey included the mud pit storage sump and the former water reservoir. The findings of the survey were not distinguishable from background readings.

\section{A.2.3 Corrective Action Site 02-09-49, Area 2 Mud Plant \#2}

Corrective Action Site 02-09-49 consists of unused drilling mud that has been placed into a former water reservoir that once was used to store water from WW-2. Water Well 2 is located approximately $120 \mathrm{ft}$ to the west-northwest of the reservoir in Area 2 of the NTS. The water from the reservoir was used for the operations around the NTS and also possibly for the manufacture of drilling muds at Mud Plant \#2. Figure A.2-3 shows a photograph of the CAS. Corrective Action Site 02-09-49 meets the criteria for a Category II CAS as defined in Section A.2.1. The mud contained within the sump was dumped into the former water reservoir and never used for drilling activities; therefore, the mud was not introduced to potential contamination associated with drilling processes. 


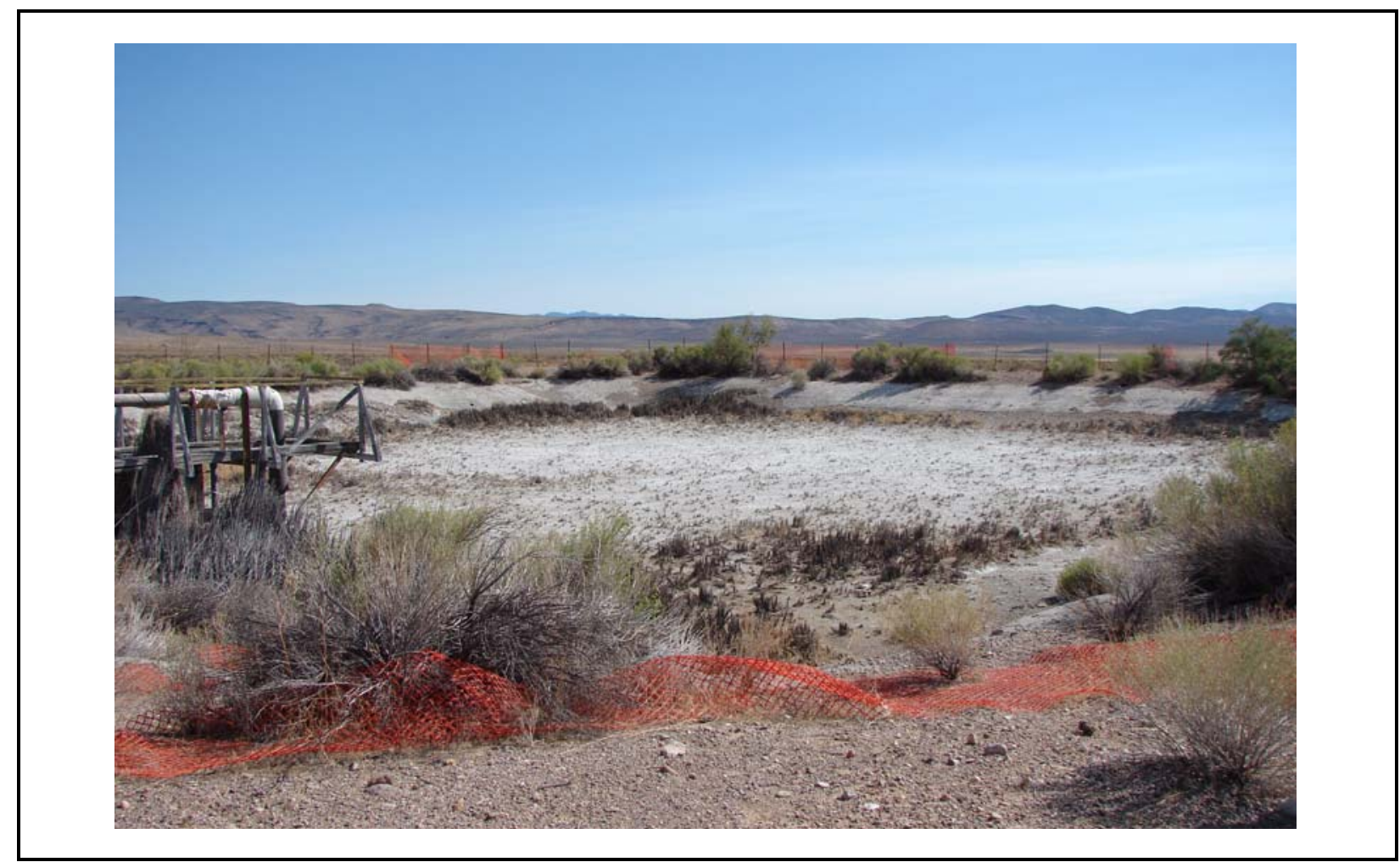

Figure A.2-3

Corrective Action Site 02-09-49, Area 2 Mud Plant \#2

Physical Setting and Operational History - Corrective Action Site 02-09-49 is located in Area 2 of the NTS. The CAS footprint is that of the reservoir once used for water storage. The reservoir was constructed before1964. The reservoir is constructed of concrete and measures approximately 177 by $177 \mathrm{ft}$ and is approximately $10 \mathrm{ft}$ deep. Unused drilling mud was placed into the former water reservoir sometime after 1997, but the exact date of placement of the drilling mud is unknown. Reed-type plants and tumbleweeds are in the reservoir. The site is currently inactive and abandoned.

Release Information - Unused drilling muds do not contain potential contaminants. No potential for release has been identified with this CAS.

Previous Investigation Results - A radiological walkover survey of CAS 02-09-49 conducted in 2003 identified a maximum gamma emission radiation that was not significantly different from background. No analytical results were identified for CAS 02-09-49. In 2006, an informal geophysical survey was conducted around the reservoir to identify the direction and possible 
association of the extensive piping that exists at the reservoir. The results of the survey only identified piping from WW-2 to the reservoir.

\section{A.2.4 Corrective Action Site 02-99-05, Mud Spill}

Corrective Action Site 02-99-05 is located outside the U-2bp-2 PS \#1A post-test cellar area in Area 2 of the NTS. The spill identified as drilling mud is actually a pile of dumped concrete. The concrete is associated with the legacy grouting operation at cellars or surface casings. The site is inactive and abandoned. Figure A.2-4 is a photograph of CAS 02-99-05, which meets the criteria for a Category II CAS as defined in Section A.2.1. There is no potential for release from the concrete that is identified as the CAS.

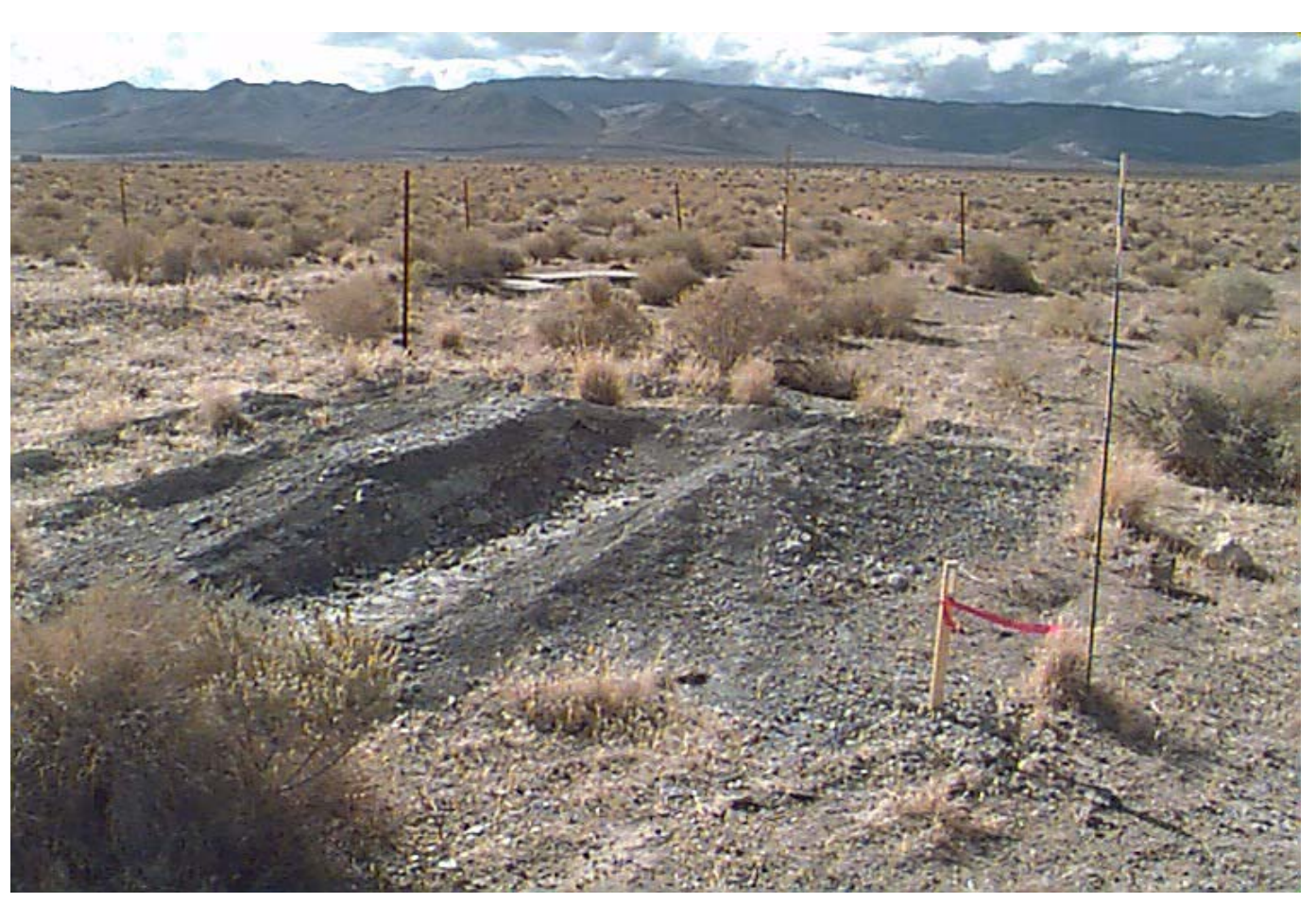

Figure A.2-4

Corrective Action Site 02-99-05, Mud Spill 
Physical Setting and Operational History - The operational history of the CAS is unknown, but it was common practice at the NTS to dump excess concrete from vehicles onto the ground adjacent to the site using the concrete. The cement pile is approximately 22 by $21 \mathrm{ft}$ in area, approximately $2 \mathrm{ft}$ at its deepest, and is located approximately $6 \mathrm{ft}$ northwest of the post-test cellar. The post-test cellar was completed on August 16, 1969, two days after the Spider A and B tests were conducted. It is unknown when the cellar was plugged. The site was first identified on October 18, 1990.

Release Information - There is no identified potential to release associated with CAS 02-99-05.

Previous Investigation Results - A sample of cement chips and soil was collected from the CAS on August 27, 1997, and analyzed for VOCs, SVOCs, radionuclides and RCRA metals. No COCs were identified above their respective action levels.

\section{A.2.5 Corrective Action Site 03-09-02, Mud Dump Trenches}

Corrective Action Site 03-09-02 is a series of mud pits associated with the drilling of the U-3kz emplacement hole. An access road divides the mud pits into a northern and southern footprint within the CAS. The site is inactive and abandoned. Figures A.2-5 and A.2-6 are photographs of the northern footprint, and Figure A.2-7 is a photograph of the southern footprint of this CAS.

Physical Setting and Operational History - Corrective Action Site 03-09-02 is located approximately $180 \mathrm{ft}$ west of the U-3kz crater in Area 3 of the NTS. The U-3kz emplacement hole was drilled in 1984. Two sets of mud pits, divided by an access road, are identified with two distinct footprints that are north and south of the access road. These footprints are the "northern" and “southern” footprints. The northern footprint contains a reserve pit and a suction pit connected by a channel. The reserve pit is approximately 155 by $155 \mathrm{ft}$ and the suction pit is approximately 155 by $10 \mathrm{ft}$. The suction pit is entirely filled with tumbleweeds and a small amount of vegetation. A discarded length of blue pipe is visible through the tumbleweeds. Another potential suction pit is located just to the northwest of the reserve pit, although there is no evidence that it was ever used, as no mud is identified within the pit. The southern footprint contains a borrow pit approximately 300 by $300 \mathrm{ft}$ and contains two distinct parallel pits approximately $150 \mathrm{ft}$ in length and connected by a channel. One pit is elevated relative to the second pit, and both pits contain drilling mud. During the drilling of the U-3kz emplacement hole, unanticipated radiation was detected. It was determined that the U-3kz emplacement hole had intercepted an underground radiation plume from the Sandreef test 
(U-7aq) conducted some seven years earlier and approximately $350 \mathrm{ft}$ to the northwest of U-3kz. Four exploratory holes were drilled to intersect the contaminant plume. Only one exploratory hole identified a narrow band of gamma activity. However, some radiation may have been brought to the surface during the drilling of the U-3kz emplacement hole.

Release Information - The potential to release exists from the drilling muds associated with the mud pits within the northern and southern footprints of CAS 03-09-02 and from any contaminated soils in contact with the drilling muds. Potential contaminants are radionuclides from the drilling muds and cuttings brought to the surface during the drilling of emplacement hole U-3kz. No COCs are anticipated to be associated with the discarded length of blue pipe in the suction pit. Corrective Action Site 03-09-02 meets the criteria for a Category III CAS as defined in Section A.2.1. Process knowledge indicates the potential for contamination to be present due to drilling activities that intercepted an unanticipated contaminant plume from another test. This process knowledge does not allow for the comparison of this CAS to the CAUs found in the Mud Pit CR, resulting in required investigation of the CAS (i.e., Category III).

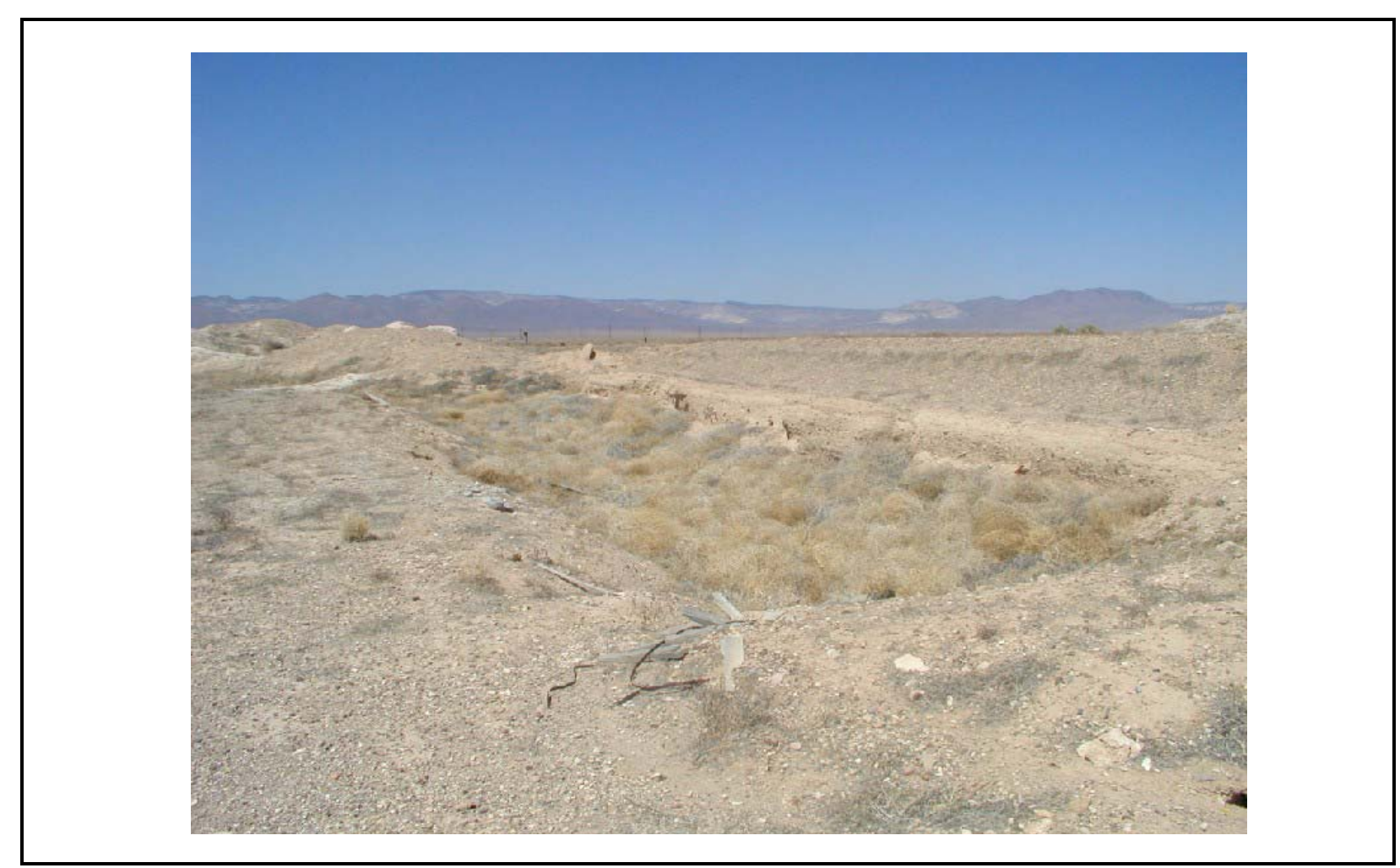

Figure A.2-5

Suction Pit in Northern Footprint of CAS 03-09-02 


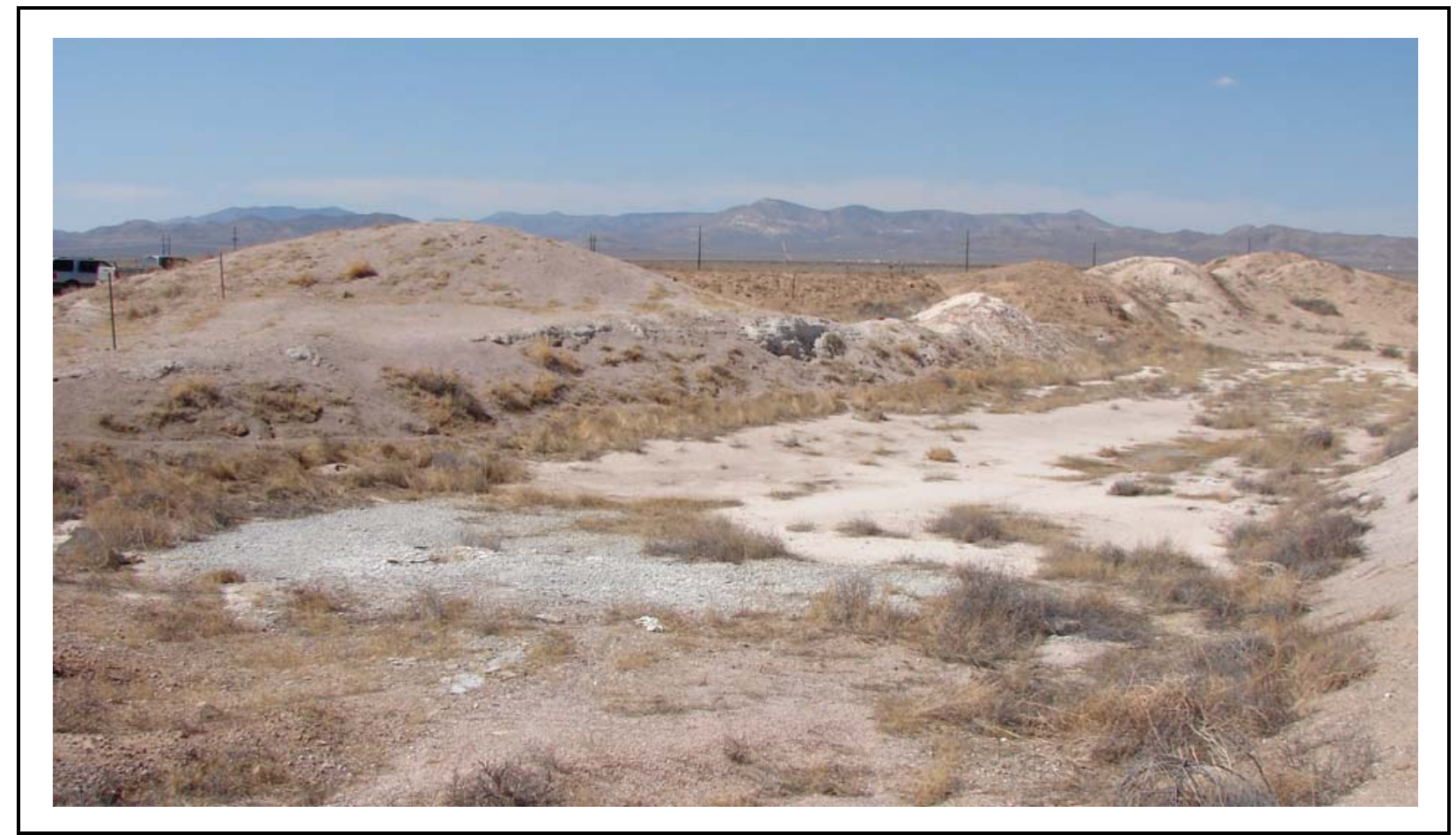

Figure A.2-6

Mud Pit in Northern Footprint of CAS 03-09-02

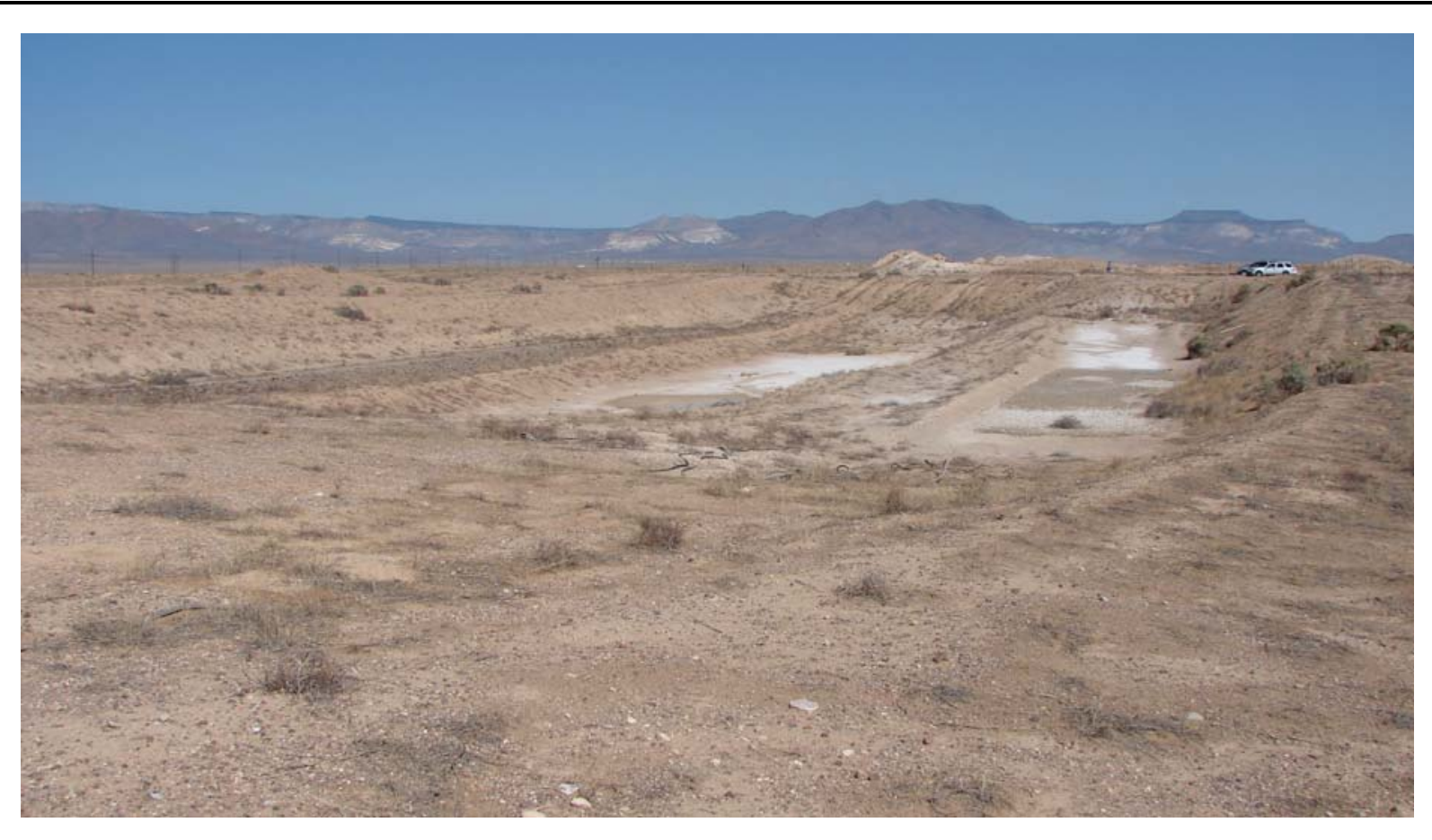

Figure A.2-7

Mud Pits in Southern Footprint of CAS 03-09-02 
Previous Investigation Results - No analytical or geophysical survey results were identified for CAS 03-09-02. A radiological survey covering approximately 29,000 square feet was conducted at CAS 03-20-02 on January 23, 2004. The CAS is located approximately $800 \mathrm{ft}$ to the south of CAS 03-09-02. Gamma emission rates at CAS 03-20-02 were not significantly above background readings.

\section{A.2.6 Corrective Action Site 04-44-02, Mud Spill}

Corrective Action Site 04-44-02 is a drilling mud spill located approximately $130 \mathrm{ft}$ northwest of the U-4at PS\#1A cellar in Area 4 of the NTS. Figure A.2-8 is a photograph of CAS 04-44-02. This CAS meets the criteria for a Category I CAS as defined in Section A.2.1, consisting of a mud spill of the type associated with CAU 535 in the Mud Pit CR.

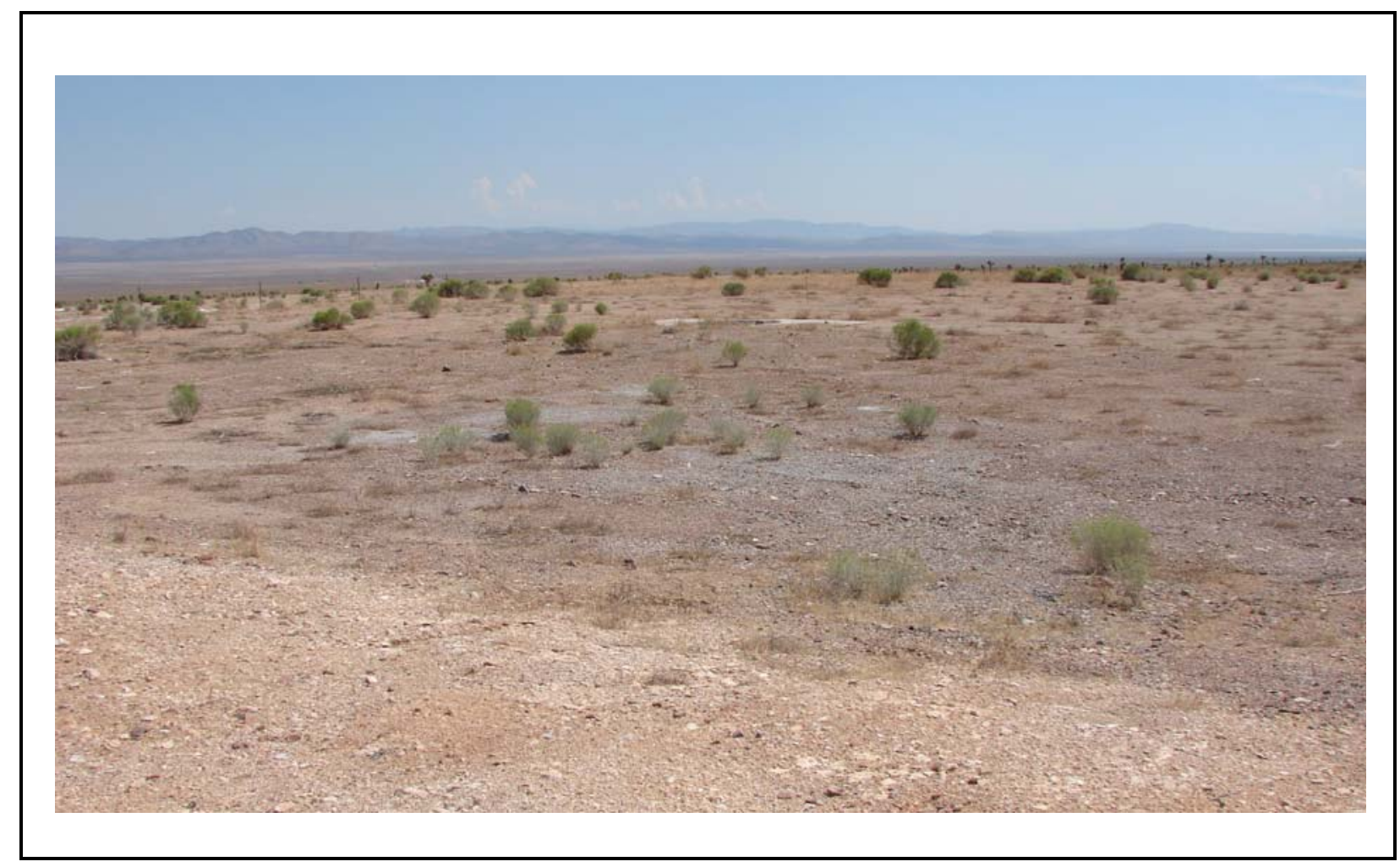

Figure A.2-8

Corrective Action Site 04-44-02, Mud Spill 
Physical Setting and Operational History - Drilling of the post-test cellar U-4at PS\#1A began on May 15 and was completed on May 18, 1989. It is believed that the mud spill is related to the drilling of the post-test cellar for the three Palisade tests. The mud spill is thinly spread with breaks of vegetation covering an area of approximately 50 by $40 \mathrm{ft}$. The spilled mud is approximately $130 \mathrm{ft}$ northwest of the U-4at PS\#1A cellar in Area 4 of the NTS. The site is inactive and abandoned.

Release Information - There is no potential to release associated with the mud spill at CAS 04-44-02.

Previous Investigation Results - A radiological walkover survey was conducted at CAS 04-44-02 on May 15, 2006. None of the results were significantly above background levels in the walkover survey. No analytical results have been identified for CAS 04-44-02.

\section{A.2.7 Corrective Action Site 04-99-02, Mud Spill}

Corrective Action Site 04-99-02 consists of a series of mud spills around and within the fenced and posted U-4at crater area in Area 4 of the NTS. No stability study has been conducted for the U-4at crater. Figure A.2-9 is a photograph of CAS 04-99-02. Corrective Action Site 04-99-02 meets the criteria for a Category I CAS as defined in Section A.2.1, and consists of a group of mud spills of the type identified as belonging to CAU 535 in the Mud Pit CR. This CAS will not be carried through the entire DQO process, and will not be sampled.

Physical Setting and Operational History - Corrective Action Site 04-99-02 consists of five mud spills (identified as “Spill Site A” through “Spill Site “E”) where some are inside, partially inside, and completely outside the fenced and posted U-4at crater area. The mud spills are believed to be associated with the drilling activities conducted at U-4at between May 16 and 18, 1987. The crater area is fenced and posted with signage reading: “Danger Crater Area Keep Out U-4AT.” There are no radiological postings at this CAS, which is inactive and abandoned.

Release Information - There is no potential to release identified with CAS 04-99-02.

Previous Investigation Results - No analytical or geophysical survey results have been identified for CAS 04-99-02. A radiological walkover survey was conducted at CAS 04-99-02 on May 15, 2006. Radiation emission results were not significantly different from background levels. 


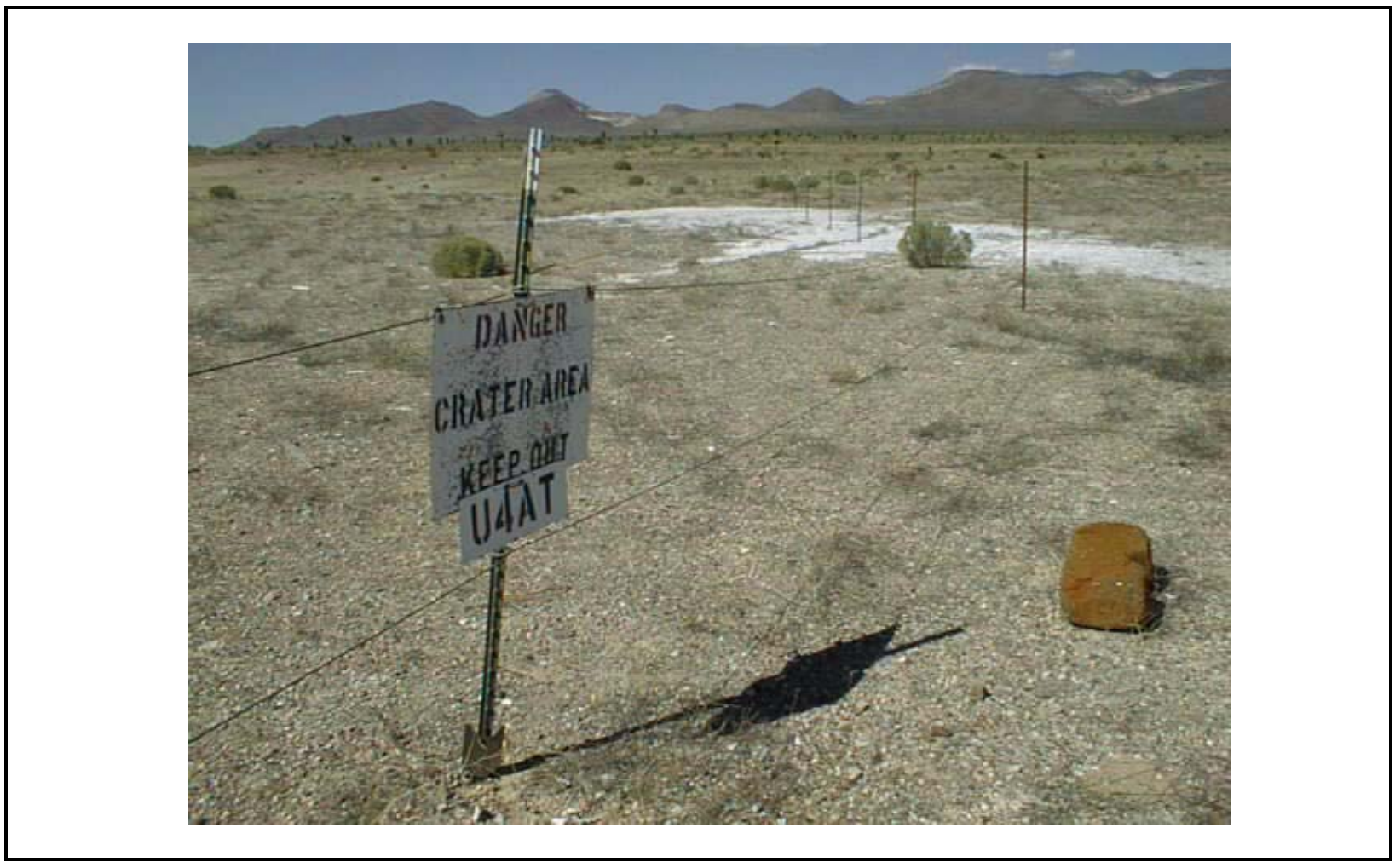

Figure A.2-9

\section{Spill Site C at CAS 04-99-02, Mud Spill}

\section{A.2.8 Corrective Action Site 12-09-01, Mud Pit}

Corrective Action Site 12-09-01 consists of three distinct footprints in Area 12 of the NTS.

Figures A.2-10 and A.2-11 are photographs of CAS 12-09-01. The site is inactive and abandoned.Corrective Action Site 12-09-01 meets the criteria for a Category III CAS as defined in Section A.2.1, due to the presence of a potential for release from of a length of metal pipe and a large piece of cylindrical-shaped metal debris. The mud pit is in a separate footprint from the debris constituting the potential to release. The mud pit is a CAU 533-type mud pit as identified in the Mud Pit CR.

Physical Setting and Operational History - Corrective Action Site 12-09-01 is a mud pit, a length of metal pipe, and a large piece of cylindrical metal debris that are identified with three distinctive footprints. The mud pit is associated with the drilling of the U-12r PS \#1A post-test cellar that was completed in December, 1968. The mud pit is approximately $30 \mathrm{ft}$ to the west of the cellar. The mud pit is approximately 100 by $25 \mathrm{ft}$ in area. The mud pit contains dry, cracked mud and little vegetation. 


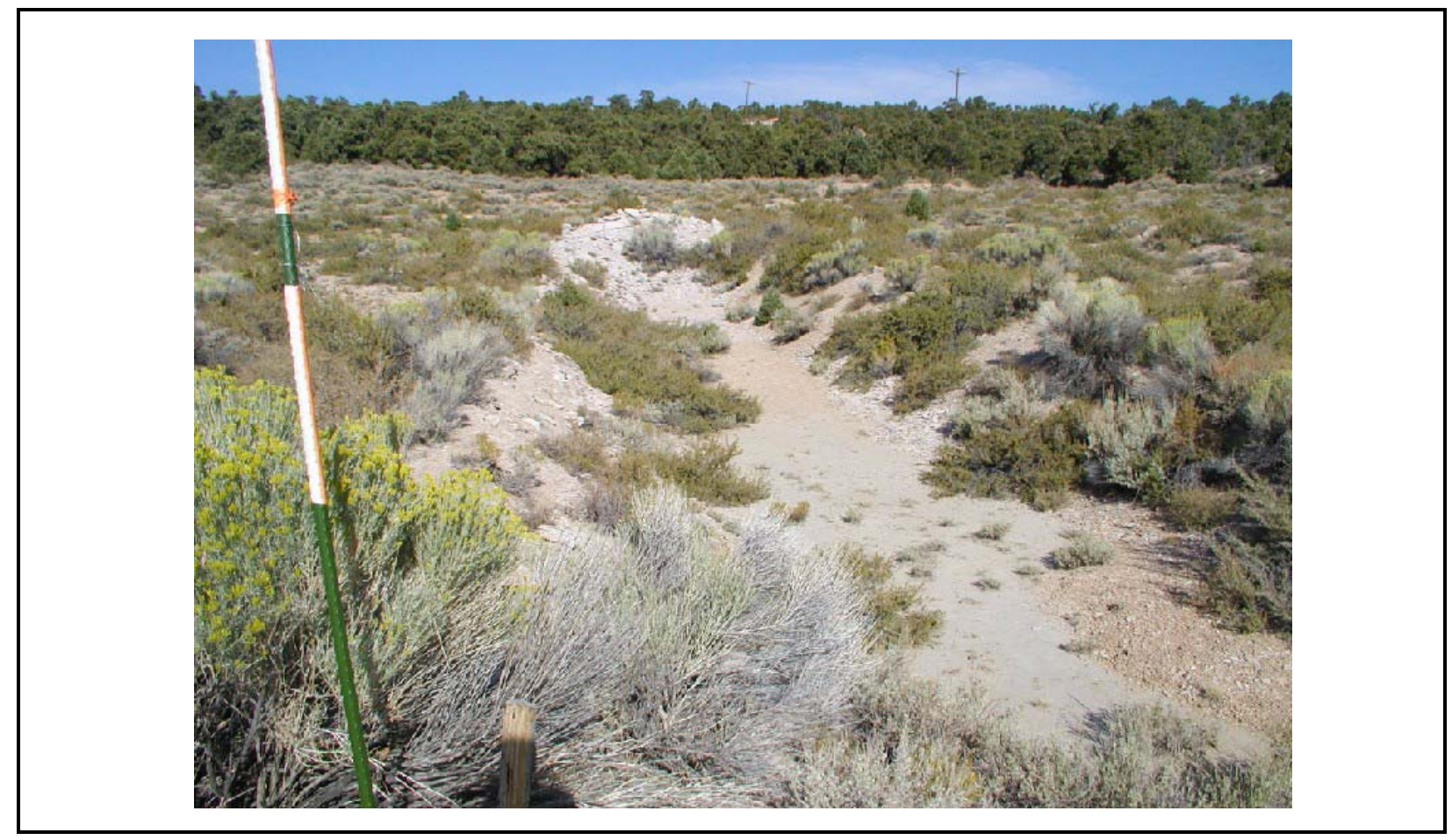

Figure A.2-10

Mud Pit Footprint in CAS 12-09-01, Mud Pit

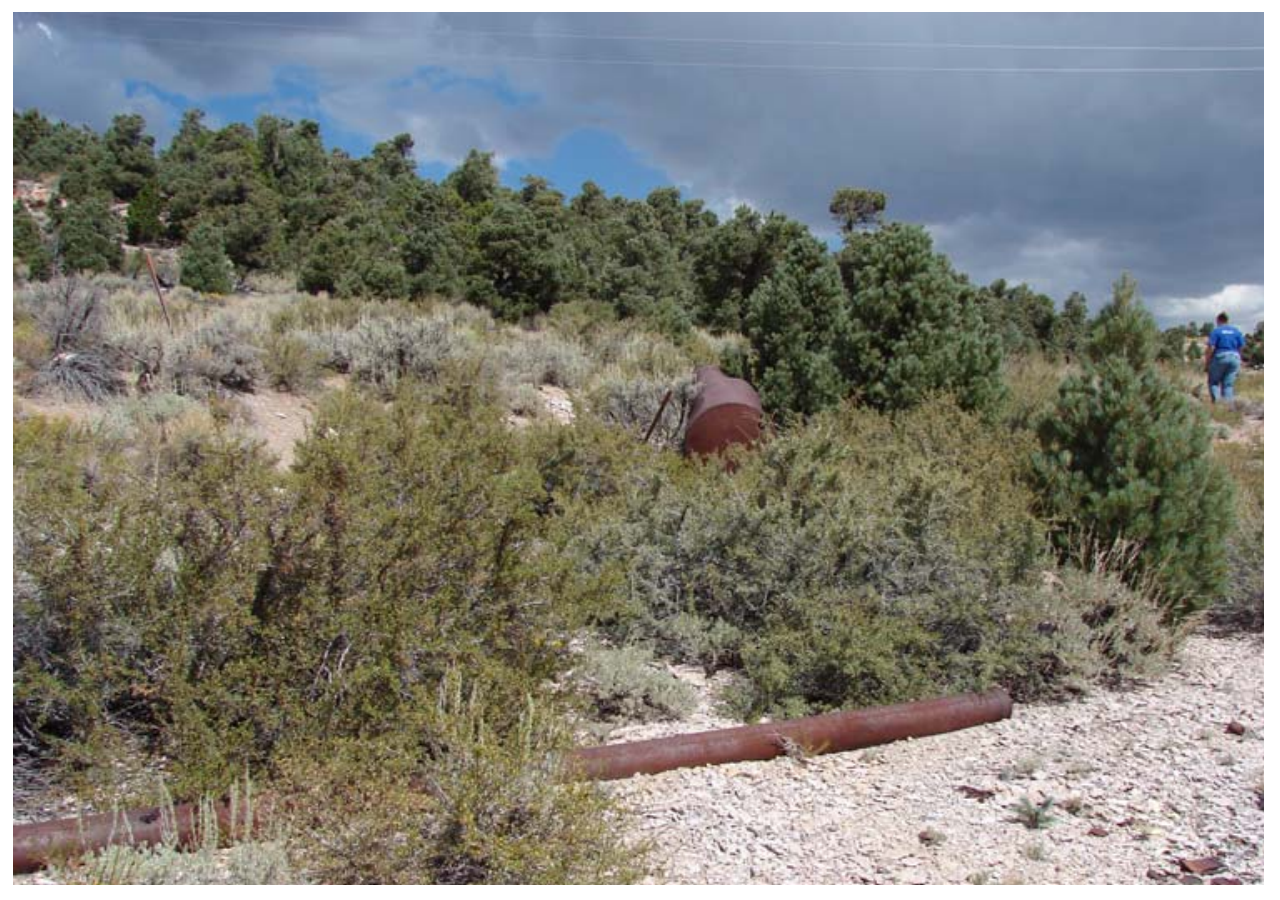

Figure A.2-11

Debris at CAS 12-09-01, Mud Pit 
A length of metal pipe and a large cylindrical piece of metal debris are located approximately $60 \mathrm{ft}$ to the northwest of the mud pit. The metal pipe is laying on the ground surface. The cylindrical metal debris is also laying on its side on the ground surface. The cylindrical metal debris has a large-spaced grid type of base, and a rectangular opening in the side that was once covered by a hinged door. Glass, rusted cans, and other debris are inside the rectangular opening that is close to the ground. It is unknown when the metal pipe and cylindrical metal debris were placed at the site. A separate footprint is associated with each of the three features of this CAS.

Release Information - There is no potential to release associated with the mud pit. A potential to release is associated with the metal pipe and cylindrical metal debris, as well as from the soil in contact with these features.

Previous Investigation Results - No analytical results have been identified for CAS 12-09-01.

\section{A.2.9 Corrective Action Site 12-09-04, Mud Pit}

Corrective Action Site 12-09-04 is a mud pit associated with the drilling of the emplacement hole U-12r, completed on October 24, 1962. During drilling, a natural drainage channel was used for the discharge of used drilling mud. The CAS is located inside and outside the fenced subsidence area around U-12r. There is no stability study associated with the U-12r crater. Figure A.2-12 is a photograph of CAS 12-09-04, which is inactive and abandoned. The CAS is associated with those classified in the Mud Pit CR as a mud pit within CAU 532. CAS 12-09-04 meets the criteria for a Category I CAS as defined in Section A.2.1.

Physical Setting and Operational History - Corrective Action Site 12-09-04 is an area of drilling mud approximately 670 by $100 \mathrm{ft}$. The site is actually characteristic of a mud spill, because the used drilling mud and cuttings were blown into a natural drainage channel and allowed to flow away freely from the emplacement hole. The channel containing the mud is covered with heavy vegetation, and the mud is only visible in some areas within the channel. A portion of the CAS is located within the fenced crater area.

Release Information - There is no potential for release associated with CAS 12-09-04.

Previous Investigation Results - No analytical results have been identified for CAS 12-09-04. 


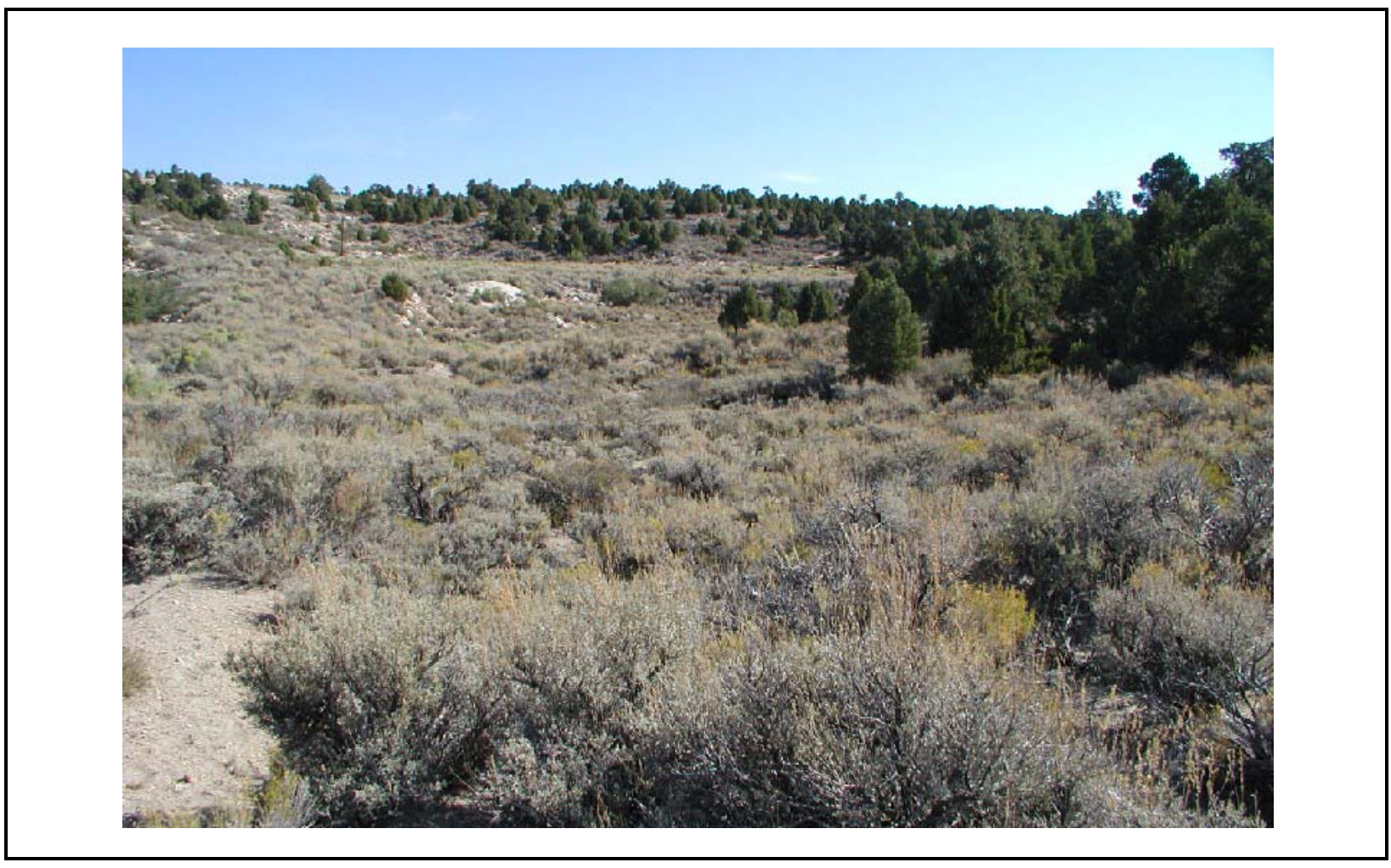

Figure A.2-12

\section{Corrective Action Site 12-09-04, Mud Pit}

\section{A.2.10 Corrective Action Site 12-09-08, Mud Pit}

Corrective Action Site 12-09-08 is a mud pit associated with the drilling of instrument hole U-12e.14 HFR CH\#1 in Area 12 of the NTS. Mud pits associated with the drilling of instrument holes are within CAU 534 in the Mud Pit CR. The mud pit itself, therefore, does not pose a potential for release in CAS 12-09-08. The site is inactive and abandoned. Figure A.2-13 is a photograph of CAS 12-09-08, which meets the criteria for a Category III CAS as defined in Section A.2.1, due to the presence of the potential for release associated with the pipe protruding from the berm wall and the crushed drums that lie along the mud/berm interface. 


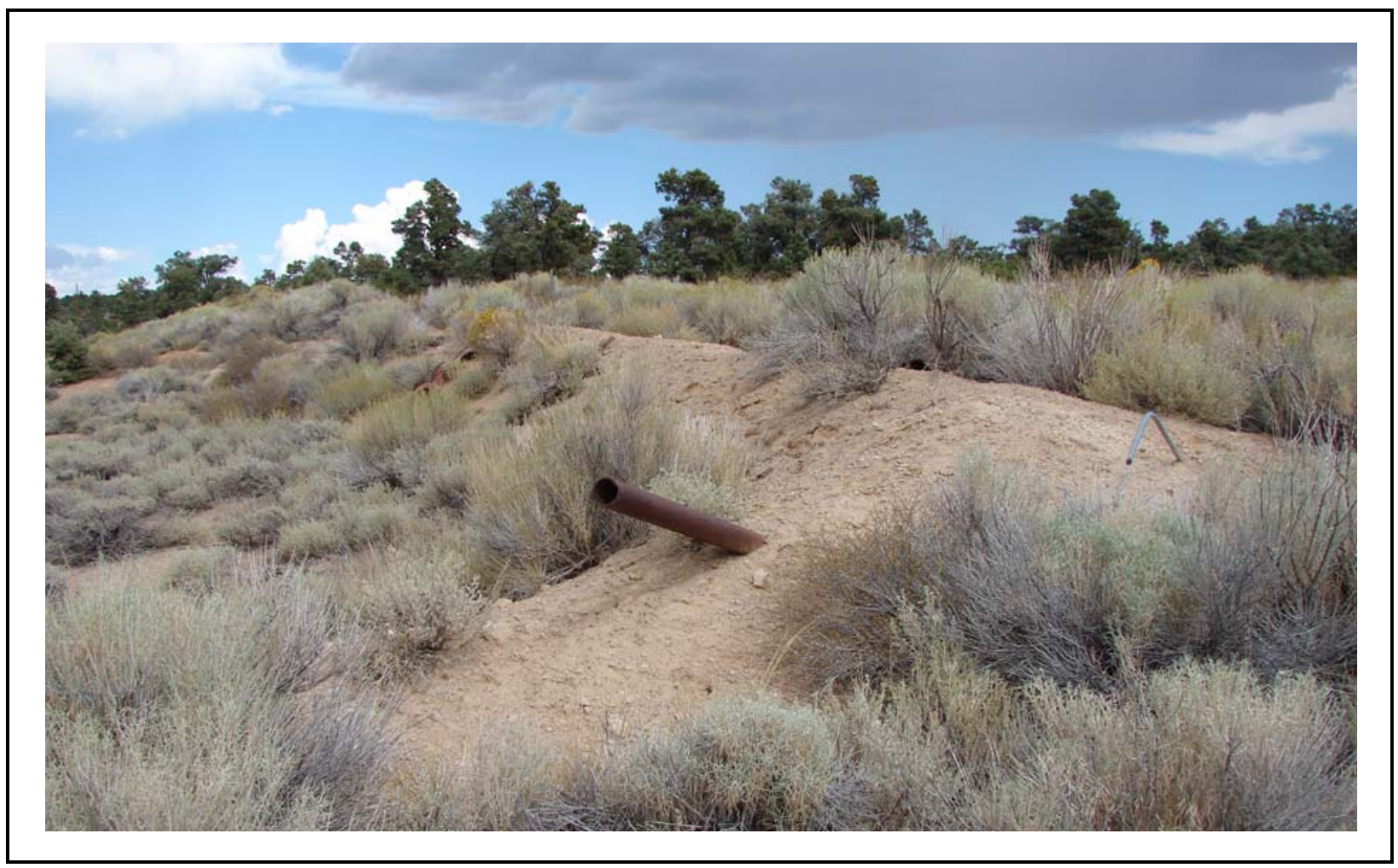

Figure A.2-13

\section{Corrective Action Site 12-09-08, Mud Pit}

Physical Setting and Operational History - Corrective Action Site 12-09-08 is a mud pit used during the drilling of the U-12e.14 HFR CH\#1 instrument hole that was completed on December 14, 1972. The mud pit area is approximately 125 by $40 \mathrm{ft}$ and is surrounded by 3 - to 5 -ft berms. The dried mud is tan to grey and some vegetation is present. A metal pipe protrudes from the southern berm wall and four crushed drums are piled at a location along the eastern berm at the wall/mud interface.

Release Information - There is a potential to release associated with the metal pipe and the crushed metal drums, as well as from the soils in contact with them. There is no potential to release from the drilling mud within the mud pit.

Previous Investigation Results - No analytical results have been identified for CAS 12-09-08. 


\section{A.2.11 Corrective Action Site 12-30-14, Cellar}

Corrective Action Site 12-30-14 is a post-test cellar in Area 12 of the NTS related to the 1969 Wineskin test. Figure A.2-14 is a photograph of CAS 12-30-14, which meets the criteria of a Category III CAS as defined in Section A.2.1. The Category III assignment results from a potential for release from the contents of the cellar and the surrounding soils.

Physical Setting and Operational History - Corrective Action Site 12-30-14 is a post-test cellar constructed January 24, 1969. The cellar is approximately $10 \mathrm{ft}$ in diameter and $9 \mathrm{ft}$ deep. The inside of the cellar is encased with corrugated metal. Liquid within the cellar is approximately $5 \mathrm{ft}$ deep. Several boards are floating on the liquid within the cellar. A metal pipe has been set in the cellar and leans up against the side, protruding some 4 to $5 \mathrm{ft}$ above ground surface. It is unknown what the liquid within the cellar consists of, but the location of the cellar in relation to the surrounding terrain suggests that an approximate 2-acre watershed may drain into the cellar. The site is inactive and abandoned.

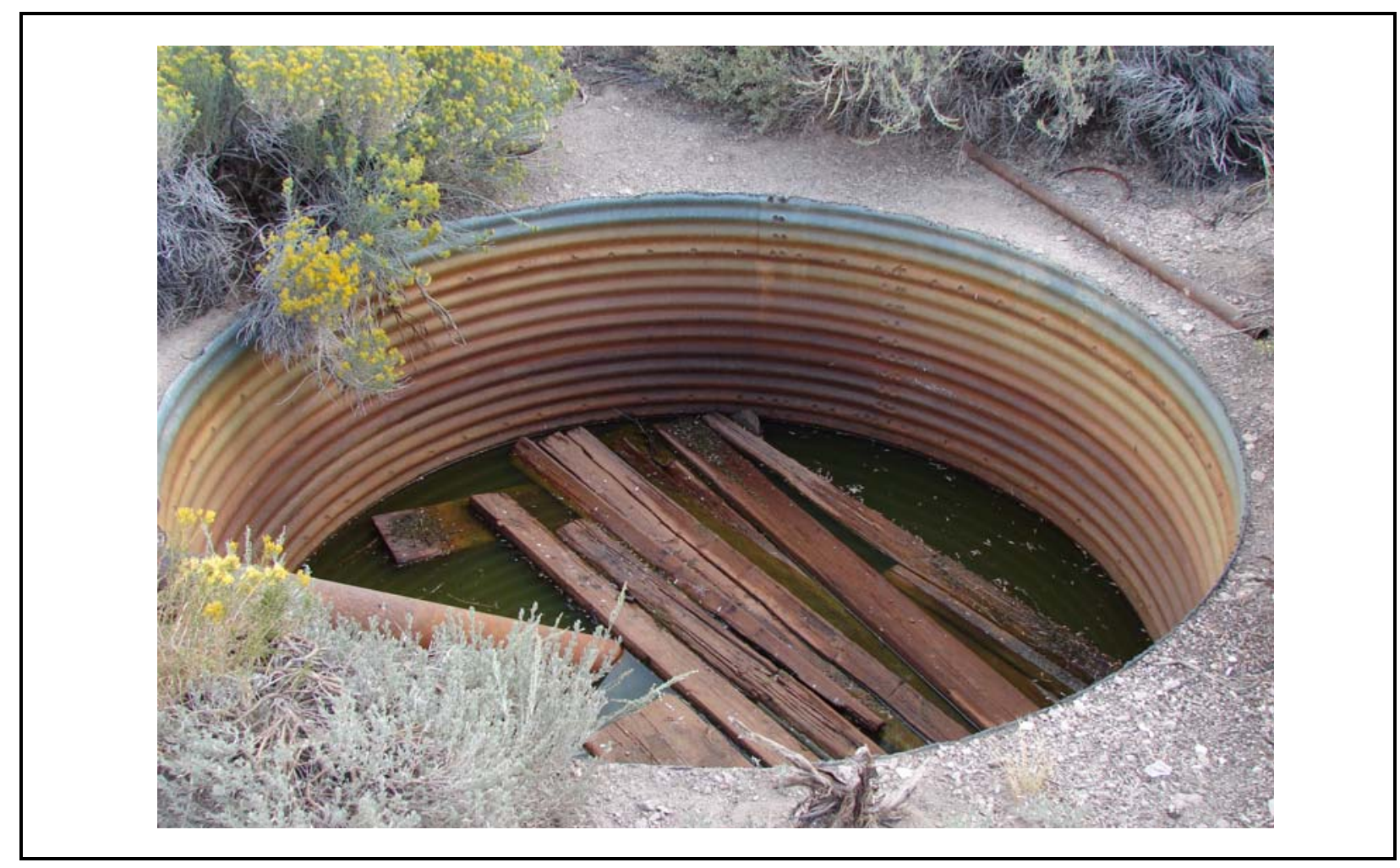

Figure A.2-14

Corrective Action Site 12-30-14, Cellar 
Release Information - There is a potential to release from the sediment and liquid within the cellar to the soils that are in contact with the subsurface portions of the cellar. There is no potential for other releases from the CAS.

Previous Investigation Results - There are no analytical results associated with CAS 12-30-14.

\section{A.2.12 Corrective Action Site 12-99-07, Mud Dump}

Corrective Action Site 12-99-07 is located at the southern end of the Area 12 Batch Plant in Area 12 of the NTS. The site is a location where vehicles transporting concrete to operations on the NTS dumped excess concrete. The site is inactive and abandoned. Figure A.2-15 is a photograph of CAS 12-99-07, which meets the criteria for a Category II CAS as defined in Section A.2.1. There is no potential to release associated with the concrete that was dumped there.

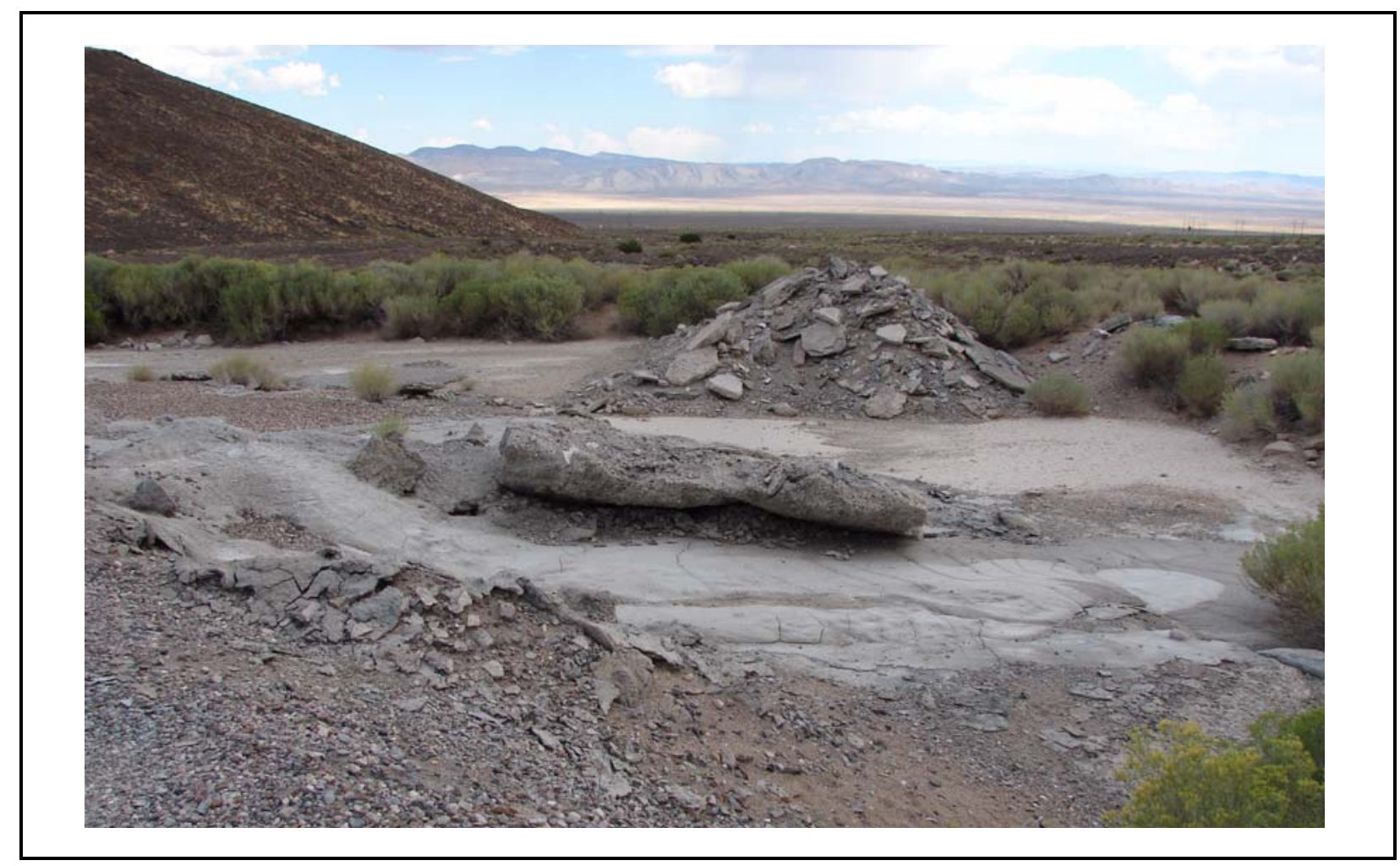

Figure A.2-15

Corrective Action Site 12-99-07, Mud Dump 
Physical Setting and Operational History - Corrective Action Site 12-99-07 is an area of dumped concrete from concrete-carrying vehicles associated with the Area 12 Batch Plant. The Batch Plant was constructed in 1974 and ceased operations in 1998. The site is inactive and abandoned.

Release Information - There is no potential release associated with CAS 12-99-07.

Previous Investigation Results - There are no analytical results associated with CAS 12-99-07.

\section{A.2.13 Corrective Action Site 15-09-01, Mud Pit}

Corrective Action Site 15-09-01 is a mud pit located north of the EPA Farm in Area 15 of the NTS. The site is inactive and abandoned. Figure A.2-16 is a photograph of CAS 15-09-01, which meets the criteria for a Category I CAS, as defined in Section A.2.1. The CAS fits the description of a CAU 535 CAS (mud spill), because the mud was not released to an engineered pit, but instead to a sloped feature that carried it to a 14-ft soil wall that caused the flow to stop. The CAS also fits the description of a CAU 534 CAS (instrument hole mud pit).

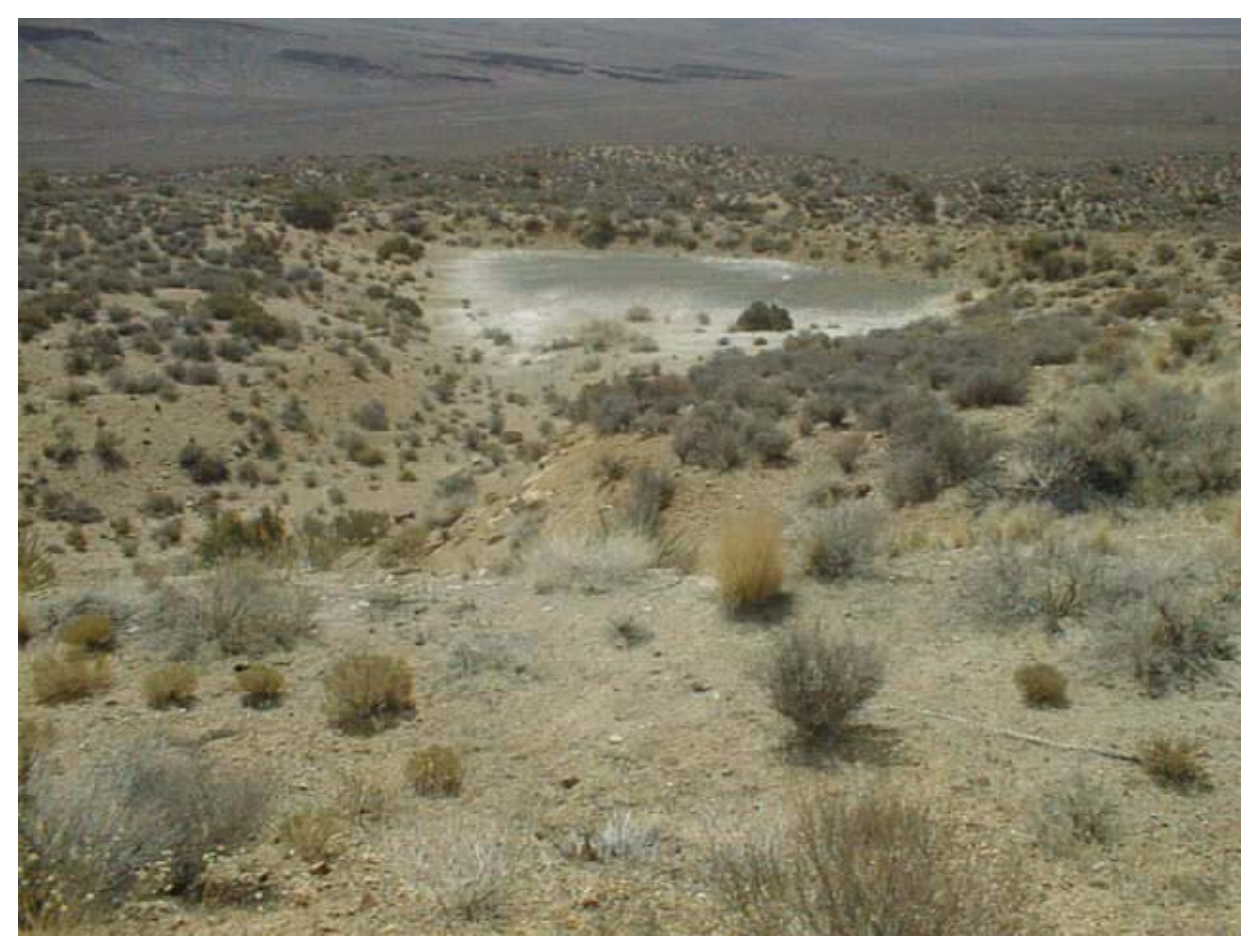

Figure A.2-16

Corrective Action Site 15-09-01, Mud Pit 
Physical Setting and Operational History - Corrective Action Site 15-09-01 is a mud pit associated with instrument hole U-15GZ \#14, completed on March 3, 1965. The mud from the drilling operation was placed into a north-south trending ravine where it flowed until a berm was encountered some $180 \mathrm{ft}$ southwest and downgradient from the drill hole. The mud pit is approximately $66 \mathrm{by} 95 \mathrm{ft}$ at its greatest dimensions.

Release Information - There is no potential to release associated with the mud pit at CAS 15-09-01.

Previous Investigation Results - Analytical results from samples collected in August 1997 and analyzed for VOCs, SVOCs, RCRA metals, and radionuclides. No analytes were identified above their respective action levels. 


\section{A.3.0 Step 1 - State the Problem}

Step 1 of the DQO process defines the problem that requires study; identifies the planning team, and develops a conceptual model of the environmental hazard to be investigated.

The problem statement for CAU 234 is: "Existing information on the nature and extent of potential contamination is insufficient to evaluate and recommend corrective action alternatives for the CASs in CAU 234.”

\section{A.3.1 Planning Team Members}

The DQO planning team consists of representatives from NDEP, NNSA/NSO, SNJV, and NSTec. The DQO planning team met on April 12, 2007, for the DQO meeting. The primary decision-makers are the NDEP and NNSA/NSO representatives.

\section{A.3.2 Conceptual Site Model}

The CSM is used to organize and communicate information about site characteristics. It reflects the best interpretation of available information at any point in time. The CSM is a primary vehicle for communicating release mechanism assumptions, potential migration pathways, or specific constraints. It provides a summary of how and where contaminants are expected to move and what impacts such movement may have. It is the basis for assessing how contaminants could reach receptors in the present and in the future. The CSM describes the most probable scenario for current conditions at each site and define the assumptions that are the basis for identifying appropriate sampling strategy and data collection methods. Accurate CSMs are important because they serve as the basis for subsequent inputs and decisions throughout the DQO process.

The CSM was developed for CAU 234 using information from the physical setting, potential contaminant sources, release information, historical background information, knowledge from similar sites, and physical and chemical properties of the potentially affected media and COPCs. 
The CSM consists of:

- Potential contaminant releases including subsequently affected media.

- Release mechanisms (the conditions associated with the release).

- Potential contaminant source characteristics including contaminants suspected to be present and contaminant-specific properties.

- Site characteristics including physical, topographical, and meteorological information.

- Migration pathways and transport mechanisms that describe the potential for migration and where the contamination may be transported.

- The locations of points of exposure where individuals or populations may come in contact with a COC associated with a CAS.

- $\quad$ Routes of exposure where contaminants may enter the receptor.

If additional elements are identified during the investigation that are outside the scope of the CSM, the situation will be reviewed and a recommendation will be made as to how to proceed. In such cases, NDEP will be notified and given the opportunity to comment on, or concur with, the recommendation.

The applicability of the CSM to each CAS is summarized in Table A.3-1 and discussed below. Table A.3-1 provides information on CSM elements that will be used throughout the remaining steps of the DQO process. Figure A.3-1 represents site conditions applicable to the CSM.

\section{A.3.2.1 Contaminant Release}

The most likely locations of the contamination and releases to the environment are the soils directly below or adjacent to the CSM surface and subsurface components (i.e., rusted drums, cellar liquid). Contaminants migrating from CASs, regardless of physical or chemical characteristics, are expected to exist at interfaces, and in the soil adjacent to disposal features in lateral and vertical directions. 
Table A.3-1

Conceptual Site Model

Description of Elements for Each CAU 234 CAS

\begin{tabular}{|c|c|c|c|c|c|}
\hline CAS Identifier & 02-09-48 & 03-09-02 & 12-09-01 & 12-09-08 & $12-30-14$ \\
\hline CAS Description & Area 2 Mud Plant \#1 & $\begin{array}{l}\text { Mud Dump } \\
\text { Trenches }\end{array}$ & Mud Pit & Mud Pit & Cellar \\
\hline Site Status & \multicolumn{5}{|c|}{ Sites are inactive and/or abandoned } \\
\hline Exposure Scenario & Remote & \multicolumn{4}{|c|}{ Occasional } \\
\hline $\begin{array}{l}\text { Sources of Potential } \\
\text { Soil Contamination }\end{array}$ & \multicolumn{4}{|c|}{ Surface disposal of discarded equipment and materials } & $\begin{array}{l}\text { Liquid and } \\
\text { sediment in } \\
\text { cellar }\end{array}$ \\
\hline $\begin{array}{l}\text { Location of } \\
\text { Contaminationl } \\
\text { Release Point }\end{array}$ & \multicolumn{4}{|c|}{ Surface soil at or near location(s) of discarded waste/materials } & $\begin{array}{l}\text { Base/walls of } \\
\text { cellar }\end{array}$ \\
\hline Amount Released & \multicolumn{5}{|c|}{ Unknown } \\
\hline Affected Media & \multicolumn{5}{|c|}{ Surface and shallow subsurface soil } \\
\hline Potential Contaminants & Unknown & Radionuclides & \multicolumn{3}{|c|}{ Unknown } \\
\hline Transport Mechanisms & \multicolumn{4}{|c|}{$\begin{array}{l}\text { Percolation of precipitation through subsurface media serves as the major } \\
\text { driving force for sub-surface migration of contaminants. Surface water } \\
\text { runoff may provide for the transportation of some contaminants within or } \\
\text { outside of the footprints of the CASs. }\end{array}$} & $\begin{array}{l}\text { Liquid from } \\
\text { the cellar may } \\
\text { provide for a } \\
\text { driving } \\
\text { mechanism } \\
\text { for } \\
\text { contaminant } \\
\text { movement in } \\
\text { both the } \\
\text { horizontal and } \\
\text { vertical } \\
\text { directions }\end{array}$ \\
\hline Migration Pathways & \multicolumn{5}{|c|}{ Vertical transport expected to dominate over lateral transport due to small surface gradients. } \\
\hline $\begin{array}{l}\text { Lateral and Vertical } \\
\text { Extent of } \\
\text { Contamination }\end{array}$ & \multicolumn{5}{|c|}{$\begin{array}{l}\text { Contamination, if present, is expected to be contiguous to the release points. } \\
\text { Concentrations are expected to decrease with distance and depth from the source. } \\
\text { Groundwater contamination is not expected. Lateral and vertical extent of COC } \\
\text { contamination is assumed to be within the spatial boundaries. }\end{array}$} \\
\hline Exposure Pathways & \multicolumn{5}{|c|}{$\begin{array}{l}\text { The potential for contamination exposure is limited to industrial and construction workers, } \\
\text { and military personnel conducting training. These human receptors may be exposed to } \\
\text { COPCs through oral ingestion, inhalation, dermal contact (absorption) of soil and/or debris } \\
\text { due to inadvertent disturbance of these materials or irradiation by radioactive materials. }\end{array}$} \\
\hline
\end{tabular}

$\mathrm{COC}=$ Contaminant of concern

$\mathrm{COPC}=$ Contaminant of potential concern 


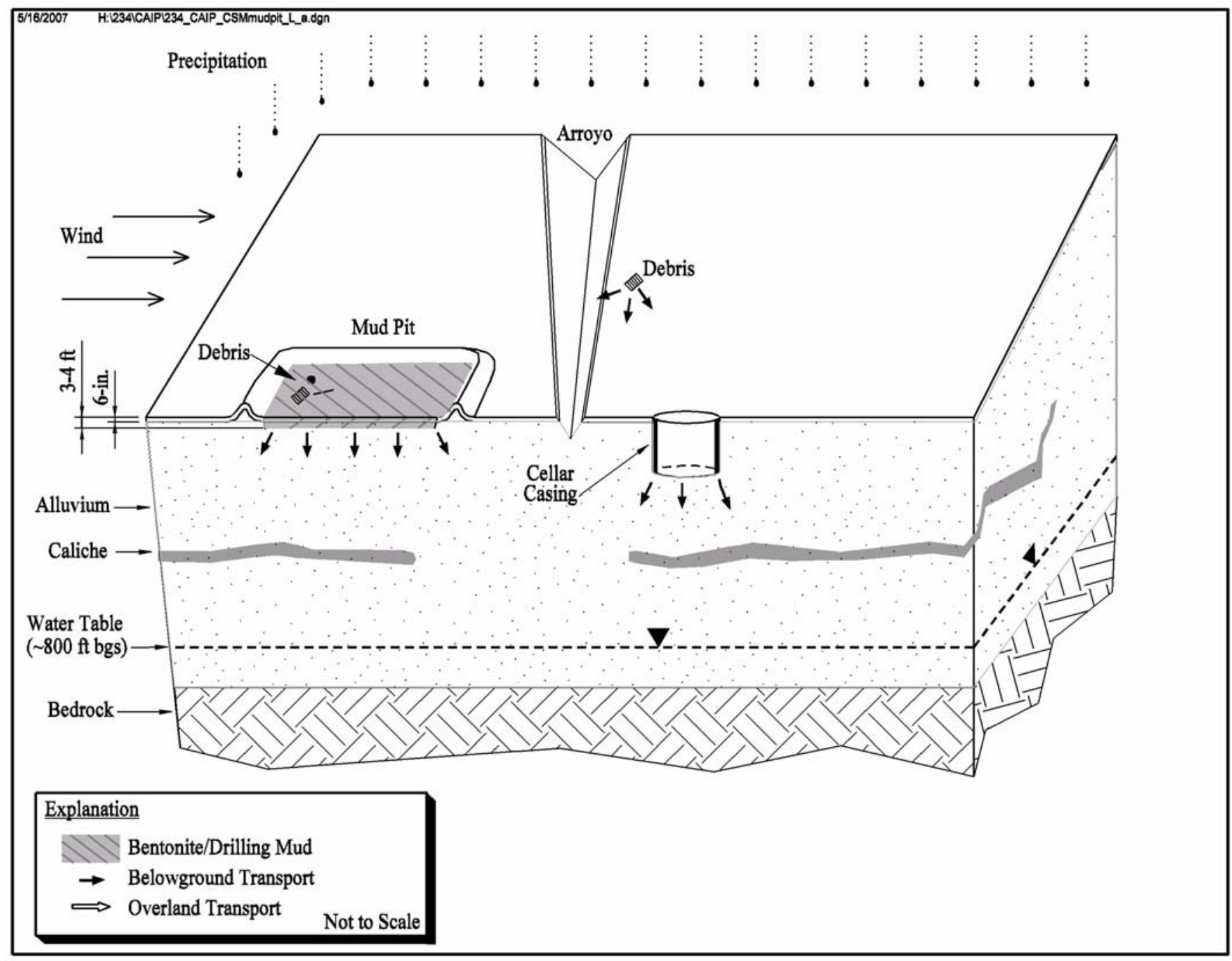

Figure A.3-1

Conceptual Site Model for CAU 234 


\section{A.3.2.2 Potential Contaminants}

The COPCs were identified during the planning process through the review of site history, process knowledge, personal interviews, past investigation efforts (where available), and inferred activities associated with the CASs. Because complete information regarding activities performed at the CAU 234 sites is not available, contaminants detected at similar NTS sites were included in the contaminant lists to reduce uncertainty. The list of COPCs is intended to encompass all of the contaminants that could potentially be present at each CAS. The COPCs applicable to Decision I environmental samples from each of the CAU 234 CASs are defined as the constituents reported from the analytical methods stipulated in Table A.3-2.

During the review of site history documentation, process knowledge information, personal interviews, past investigation efforts (where available), and inferred activities associated with the CASs, the COPCs identified were evaluated for consideration as targeted contaminants at the CAU 234 CASs. Targeted contaminants are those COPCs for which evidence in the available site and process information suggests that they may be reasonably suspected to be present at a given CAS. The targeted contaminants are required to meet a more stringent completeness criteria than other COPCs thus providing greater protection against a decision error. No targeted contaminants were identified at any of the CAU 234 CASs.

\section{A.3.2.3 Contaminant Characteristics}

Contaminant characteristics include, but are not limited to: solubility, density, and adsorption potential. In general, contaminants with low solubility, high affinity for media, and high density can be expected to be found relatively close to release points. Contaminants with small particle size, high solubility, low density, and/or low affinity for media are found further from release points or in low areas where evaporation of ponding will concentrate dissolved contaminants. 
Table A.3-2

Analytical Program ${ }^{a}$

(Includes Waste Characterization Analyses)

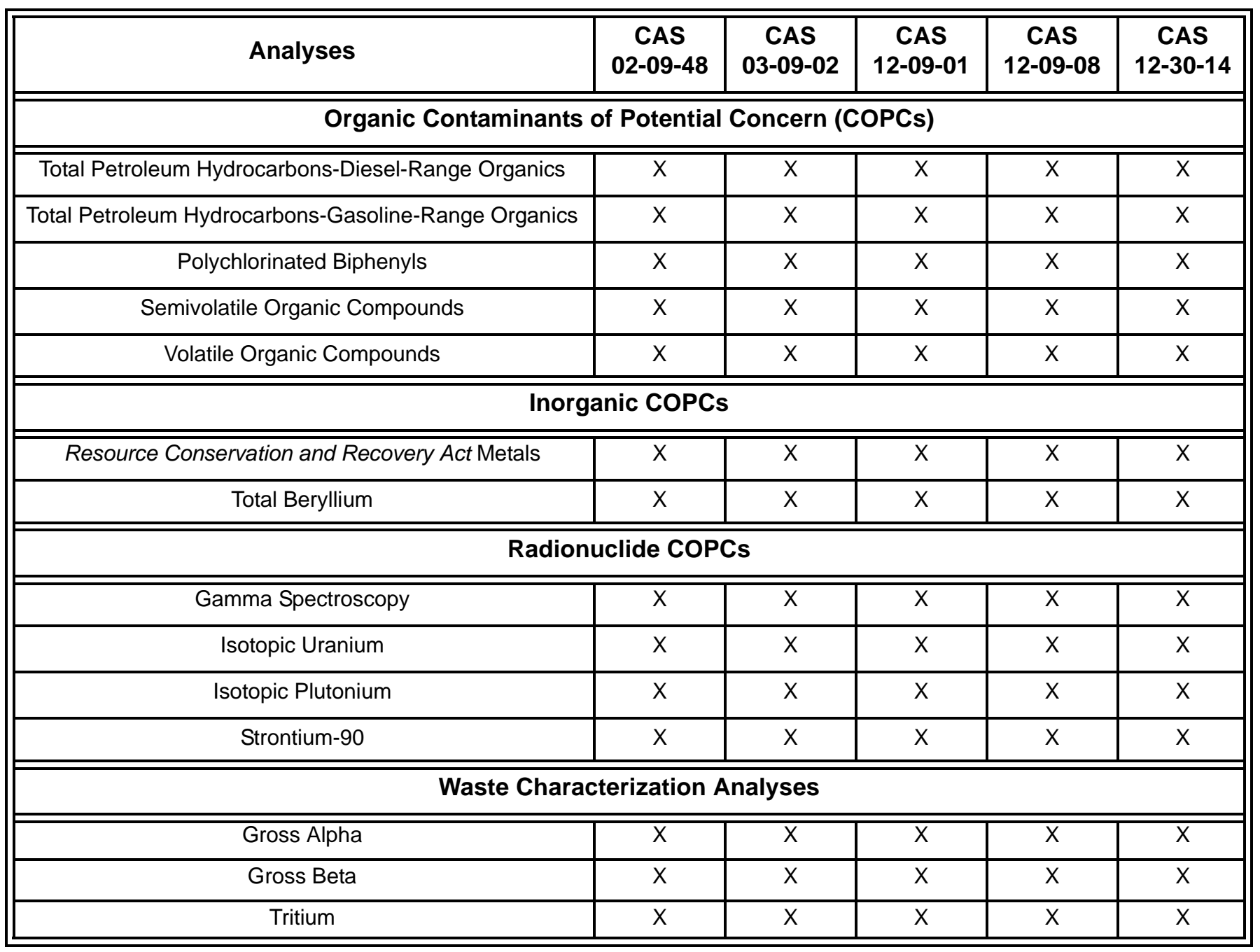

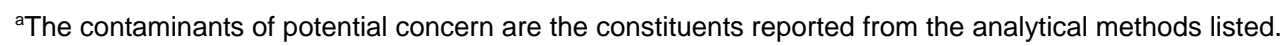

$X=$ Required analytical method

\section{A.3.2.4 Site Characteristics}

Site characteristics are defined by the interaction of physical, topographical, and meteorological attributes and properties. Physical properties include permeability, porosity, hydraulic conductivity, degree of saturation, sorting, chemical composition, and organic content. Topographical and meteorological properties and attributes include slope stability, precipitation frequency and amounts, precipitation runoff pathways, drainage channels and ephemeral streams, and evapotranspiration potential. 


\section{A.3.2.5 Migration Pathways and Transport Mechanisms}

Migration pathways include the lateral migration of potential contaminants across surface soils/sediments and vertical migration of potential contaminants through subsurface soils. All CASs but one (12-09-01) undergoing sampling is restricted in contaminant transport across surface soils/sediments by the presence of mud pit berms. Transport of contaminants across soils/sediments at CAS 12-09-01 is limited due to the gradual sloping of the area containing the release potential.

Infiltration and percolation of precipitation serves as a driving force for downward migration of contaminants. However, due to high potential evapotranspiration (annual potential evapotranspiration at the Area 3 Radiological Waste Management Site has been estimated at 62.6 in. [Shott et al., 1997]) and limited precipitation for this region (6.7 in. annually for Area 2, 12.82 in. annually for Area 12, and 7.47 in. annually for Area 15 [ARL/SORD, 2007]), percolation of infiltrated precipitation at the NTS does not provide a significant mechanism for vertical migration of contaminants to groundwater (DOE/NV, 1992).

\section{A.3.2.6 Exposure Scenarios}

Human receptors may be exposed to COPCs through oral ingestion, inhalation, dermal contact (absorption) of soil or debris due to inadvertent disturbance of these materials or irradiation by radioactive materials. The land-use and exposure scenarios for the CAU 234 CASs are listed in Table A.3-3. These are based on NTS current and future land use. Although CAS 02-09-48 is located in an area where structures from past activities exist, no facilities are present that would allow these to be used as an assigned work station for NTS site personnel. However, as site personnel may periodically perform work at this site, it is considered to be a remote work area. Corrective Action Sites 03-09-02, 12-09-01, and 12-09-08 are at remote locations without improvements and where no regular work is performed. There is still the possibility, however, that site workers could occupy these locations on an occasional and temporary basis such as a military exercise. Therefore, these sites are classified as occasional work areas. 
Table A.3-3

Land-Use and Exposure Scenarios for Category III CASs

\begin{tabular}{|c|c|c|}
\hline CAS & Record of Decision Land-Use Zone & Exposure Scenario \\
\hline $\begin{array}{l}03-09-02 \\
12-09-01 \\
12-09-08 \\
12-30-14\end{array}$ & \multirow{2}{*}{$\begin{array}{l}\text { Nuclear and High Explosives Test } \\
\text { This area is designated within the Nuclear Test Zone } \\
\text { for additional underground nuclear weapons tests and } \\
\text { outdoor high-explosive tests. This zone includes } \\
\text { compatible defense and nondefense research, } \\
\text { development, and testing activities. }\end{array}$} & $\begin{array}{l}\text { Remote Work Area } \\
\text { Worker will be exposed to the site part time } \\
\text { (up to } 336 \text { hours per year for } 25 \text { years). Site } \\
\text { structures are present for shelter and comfort } \\
\text { of the worker. }\end{array}$ \\
\hline $02-09-48$ & & $\begin{array}{l}\text { Occasional Use Area } \\
\text { Worker will be exposed to the site occasionally } \\
\text { (up to } 80 \text { hours per year for } 5 \text { years). Site } \\
\text { structures are not present for shelter and } \\
\text { comfort of the worker. }\end{array}$ \\
\hline
\end{tabular}




\section{A.4.0 Step 2 - Identify the Goal of the Study}

Step 2 of the DQO process states how environmental data will be used in meeting objectives and solving the problem, identifies study questions or decision statement(s), and considers alternative outcomes or actions that can occur upon answering the question(s).

\section{A.4.1 Decision Statements}

The Decision I statement is: "Is any COC present in environmental media within the CAS?” For judgmental sampling design, any analytical result for a COPC above the FAL will result in that COPC being designated as a COC. For probability (random) sampling design, any COPC that has a 95 percent upper confidence limit of the average concentration above the FAL will result in that COPC being designated as a COC. A COC may also be defined as a contaminant that, in combination with other like contaminants, is determined to jointly pose an unacceptable risk based on a multiple constituent analysis (NNSA/NSO, 2006b). If a COC is detected, then Decision II must be resolved.

The Decision II statement is: "If a COC is present, is sufficient information available to evaluate potential corrective action alternatives?” Sufficient information is defined to include:

- Identifying the volume of media containing any COC bounded by analytical sample results in lateral and vertical directions.

- The information needed to determine potential remediation waste types.

- The information needed to evaluate the feasibility of remediation alternatives (bioassessment if natural attenuation or biodegradation is considered, and geotechnical data if construction or evaluation of barriers is considered).

A corrective action will be determined for each site containing a COC. The evaluation of the need for corrective action will include the potential for wastes that are present at a site to cause the future contamination of site environmental media if the wastes were to be released. To evaluate the potential for cellar contents to result in the introduction of a COC to the surrounding environmental media, the following conservative assumptions were made: 
- The tank containment would fail at some point and the contents would be released to the surrounding media.

- The resulting concentration of contaminants in the surrounding media would be equal to the concentration of contaminants in the cellar waste.

- Any liquid contaminant in the cellar exceeding the RCRA toxicity characteristic concentration can result in a COC introduction into the surrounding media.

Sediments containing a contaminant exceeding an equivalent FAL concentration would be considered to be potential source material and would require a corrective action. Cellar liquids with contaminant concentrations exceeding an equivalent toxicity characteristic action level would be considered a potential source material and require a corrective action.

If sufficient information is not available to evaluate potential corrective action alternatives, then site conditions will be re-evaluated and additional samples collected (as long as the scope of the investigation is not exceeded and any CSM assumption has not been shown to be incorrect).

\section{A.4.2 Alternative Actions to the Decisions}

In this section, the actions that may be taken to solve the problem are identified depending on the possible outcomes of the investigation.

\section{A.4.2.1 Alternative Actions to Decision I}

If no COC associated with a release from the CAS is detected, then further assessment of the CAS is not required. If a COC associated with a release from the CAS is detected, then the extent of COC contamination will be determined and additional information required to evaluate potential corrective action alternatives.

\section{A.4.2.2 Alternative Actions to Decision II}

If sufficient information is available to evaluate potential corrective action alternatives, then further assessment of the CAS is not required. If sufficient information is not available to evaluate potential corrective action alternatives, then additional samples will be collected. 


\section{A.5.0 Step 3 - Identify Information Inputs}

Step 3 of the DQO process identifies the information needed, determines the sources for information, and identifies sampling and analysis methods that will allow reliable comparisons with FALs.

\section{A.5.1 Information Needs}

To resolve Decision I (determine whether a COC is present at a given CAS), samples need to be collected and analyzed following these two criteria:

- Samples must be either (a) collected in areas most likely to contain a COC (judgmental sampling) or (b) properly represent contamination at the CAS (probabilistic sampling)

- The analytical suite selected must be sufficient to identify any COCs present in the samples.

To resolve Decision II (determine whether sufficient information is available to evaluate potential corrective action alternatives at each CAS), samples need to be collected and analyzed to meet the following criteria:

- Samples must be collected in areas contiguous to the contamination but where contaminant concentrations are below FALs.

- Samples of the waste or environmental media must provide sufficient information to determine potential remediation waste types.

- Samples of the waste in cellar must provide sufficient information to determine whether they contain potential source material.

- Appropriate samples must be submitted to evaluate the feasibility of remediation alternatives (e.g., bioassessment if natural attenuation or biodegradation is considered, and geotechnical data if construction or evaluation of barriers is considered).

- The analytical suites selected must be sufficient to detect contaminants at concentrations equal to or less than their corresponding FALs.

\section{A.5.2 Sources of Information}

Information to satisfy Decision I and Decision II will be generated by collecting environmental samples using grab sampling, hand augering, or other appropriate sampling methods. These samples 
will be submitted to analytical laboratories meeting the quality criteria stipulated in the Industrial Sites QAPP (NNSA/NV, 2002a). Only validated data from analytical laboratories will be used to make DQO decisions. Sample collection and handling activities will follow standard procedures.

\section{A.5.2.1 Sample Locations}

Design of the sampling approaches for the CAU 234 CASs must ensure that the data collected are sufficient for selection of the corrective action alternatives (EPA, 2002). To meet this objective, the samples collected from each site will be from locations that most likely contain a COC, if present (judgmental). These sample locations will be selected by means of biasing factors (e.g., a stain, likely containing a spilled substance).

Decision I sample locations at CASs 02-09-48, 03-09-02, 12-09-01, and 12-09-08 will be determined based upon the likelihood of the soil containing a COC, if present at the CAS. These locations will be selected based on field-screening techniques, biasing factors, the CSM, and existing information.

Decision I sampling locations at CAS 12-30-14 will be determined based upon the likelihood of the liquid and sediment containing a COC, if present. Representative samples will be collected from the potentially contaminated environmental media present within the cellar. The analytical suite for Decision I samples will include all COPCs identified in Table A.3-2.

Biasing factors may also be used to select samples to be submitted for laboratory analyses based on existing site information and conditions discovered during the investigation. The following factors will also be considered in selecting locations for analytical samples at CAU 234:

- Documented process knowledge on source and location of release (e.g., volume of release).

- Stains: Any spot or area on the soil surface that may indicate the presence of a potentially hazardous liquid. Typically, stains indicate an organic liquid such as an oil has reached the soil, and may have spread out vertically and horizontally.

- Elevated radiation from walkover surface area radiological surveys: A radiological survey instrument will be used over approximately 100 percent of the CAS boundaries, as permitted by terrain and field conditions, to detect locations of elevated radioactivity. Any location identified during radiological surveys that had alpha/beta/gamma levels significantly higher than surrounding background soil. 
- Drums, containers, equipment or debris: Materials of interest that may have been used at, or added to, a location, and that may have contained or come in contact with hazardous or radioactive substances at some point during their use.

- Preselected areas based on process knowledge of the contaminant(s): Locations that may reasonably have received contamination, selected on the basis of the chemical and/or physical properties of the contaminant(s) in that environmental setting.

- Experience and data from investigations of similar sites.

- Other biasing factors: Factors not previously defined for the CAI, but become evident once the investigation of the site is under way.

Decision II sample step-out locations will be selected based on the CSM, biasing factors, and existing data. Analytical suites will include those parameters that exceeded FALs (i.e., COCs) in prior samples. Biasing factors to support Decision II sample locations include Decision I biasing factors plus available analytical results.

\section{A.5.2.2 Analytical Methods}

Analytical methods are available to provide the data needed to resolve the decision statements. The analytical methods and laboratory requirements (e.g., detection limits, precision, and accuracy) are provided in Tables 3-3 and A.3-2. 


\section{A.6.0 Step 4 - Define the Boundaries of the Study}

Step 4 of the DQO process defines the target population of interest and its relevant spatial boundaries, specifies temporal and other practical constraints associated with sample/data collection, and defines the sampling units on which decisions or estimates will be made.

\section{A.6.1 Target Populations of Interest}

The population of interest to resolve Decision I ("Is any COC present in environmental media within the CAS?”) is any location within the site that is contaminated with any contaminant above a FAL (judgmental sampling). The populations of interest to resolve Decision II ("If a COC is present, is sufficient information available to evaluate potential corrective action alternatives?”) are:

- Each one of a set of locations bounding contamination in lateral and vertical directions.

- Potential remediation waste.

- Environmental media where natural attenuation or biodegradation or construction/evaluation of barriers is considered.

\section{A.6.2 Spatial Boundaries}

Spatial boundaries are the maximum lateral and vertical extent of expected contamination at each CAS, as shown in Table A.6-1. Contamination found beyond these boundaries may indicate a flaw in the CSM and require re-evaluation of the CSM before the investigation can continue. Each CAS is considered geographically independent and intrusive activities are not intended to extend into the boundaries of neighboring CASs.

\section{A.6.3 Practical Constraints}

The NTS-controlled activities may affect the ability to characterize some CASs. The constraints for each CAS will be addressed in this section. The practical constraints that may affect activities at NTS include underground and overhead utilities, topography, access restrictions (e.g., scheduling conflicts at the NTS) and physical obstructions. 
Table A.6-1

Spatial Boundaries of CAU 234 CASs

\begin{tabular}{||c|l|}
\hline CAS & \multicolumn{1}{|c|}{ Spatial Boundaries } \\
\hline \hline $02-09-48$ & The footprint of the mud sump; the base of the concrete sump vertically. \\
\hline $03-09-02$ & $\begin{array}{l}\text { The footprint of each mud pit plus a 30-foot (ft) lateral buffer; } 14 \mathrm{ft} \text { below ground surface } \\
\text { (bgs) vertically. }\end{array}$ \\
\hline $12-09-01$ & The footprint of the mud pit plus a 30-ft lateral buffer; $14 \mathrm{ft}$ bgs vertically. \\
\hline $12-09-08$ & The footprint of each article of debris plus a 50 -ft lateral buffer; $14 \mathrm{ft}$ bgs vertically. \\
\hline $12-30-14$ & The physical dimensions of the cellar laterally; $14 \mathrm{ft}$ bgs vertically. \\
\hline
\end{tabular}

Practical constraints such as military activities at the NTS, weather (i.e., high winds, rain, lightning, extreme heat), utilities, threatened or endangered animal and plants, unstable or steep terrain, and/or access restrictions may affect the ability to investigate these sites. The practical constraints associated with the investigation of the CAU 234 CASs are summarized in Table A.6-2.

Table A.6-2

Practical Constraints for the CAU 234 Field Investigation

\begin{tabular}{|c|l|}
\hline \multicolumn{1}{|c|}{ CAS } & \multicolumn{1}{|c|}{ Practical Constraints } \\
\hline \hline $02-09-48$ & Weather (i.e., high winds, rain, lightning, extreme heat), slopes of mud sump \\
\hline $03-09-02$ & $\begin{array}{l}\text { Weather (i.e., high winds, rain, lightning, extreme heat), underground utilities, slopes of } \\
\text { mud pits, heavy vegetation in suction pit, unconsolidated terrain }\end{array}$ \\
\hline $12-09-01$ & $\begin{array}{l}\text { Weather (i.e., high winds, rain, lightning, extreme heat), and loose and unconsolidated } \\
\text { terrain, Nevada Test Site (NTS) activities }\end{array}$ \\
\hline $12-09-08$ & $\begin{array}{l}\text { Weather (i.e., high winds, rain, lightning, extreme heat), slope of mud pit, } \\
\text { unconsolidated terrain, NTS activities }\end{array}$ \\
\hline $12-30-14$ & $\begin{array}{l}\text { Weather (i.e, high winds, rain, lightning, extreme heat); open cellar, wood debris around } \\
\text { cellar, difficult vehicle access (four-wheel drive required), NTS activities }\end{array}$ \\
\hline
\end{tabular}

\section{A.6.4 Define the Sampling Units}

The scale of decision-making in Decision I is defined as the CAS. Any COC detected at any location within the CAS will cause the determination that the CAS is contaminated and needs further evaluation. The scale of decision-making for Decision II is defined as a contiguous area contaminated with any COC originating from the CAS. Resolution of Decision II requires this contiguous area to be bounded laterally and vertically. 


\section{A.7.0 Step 5 - Develop the Analytic Approach}

Step 5 of the DQO process specifies appropriate population parameters for decision-making, defines action levels, and generates an "If ... then ... else" decision rule that involves it.

\section{A.7.1 Population Parameters}

For judgmental sampling results, the population parameter is the observed concentration of each contaminant from each individual analytical sample. Each sample result will be compared to the FALs to determine the appropriate resolution to Decision I and Decision II. For Decision I, a single sample result for any contaminant exceeding a FAL would cause a determination that a COC is present within the CAS.

The Decision II population parameter is an individual analytical result from a bounding sample. For Decision II, a single bounding sample result for any contaminant exceeding a FAL would cause a determination that the contamination is not bounded.

\section{A.7.2 Action Levels}

The PALs presented in this section are to be used for site screening purposes. They are not necessarily intended to be used as clean-up action levels or FALs. However, they are useful in screening out contaminants that are not present in sufficient concentrations to warrant further evaluation and, therefore, streamline the consideration of remedial alternatives. The RBCA process used to establish FALs is described in the Industrial Sites Project Establishment of Final Action Levels (NNSA/NSO, 2006b). This process conforms with NAC Section 445A.227, which lists the requirements for sites with soil contamination (NAC, 2006a). For the evaluation of corrective actions, NAC Section 445A.22705 (NAC, 2006b) requires the use of ASTM Method E 1739-95 (ASTM, 1995) to "conduct an evaluation of the site, based on the risk it poses to public health and the environment, to determine the necessary remediation standards (i.e., FALs) or to establish that corrective action is not necessary." 
This RBCA process defines three tiers (or levels) of evaluation involving increasingly sophisticated analyses:

- Tier 1 evaluation - Sample results from source areas (highest concentrations) are compared to action levels based on generic (non-site-specific) conditions (i.e., the PALs established in the CAIP). The FALs may then be established as the Tier 1 action levels or the FALs may be calculated using a Tier 2 evaluation.

- Tier 2 evaluation - Conducted by calculating Tier 2 SSTLs using site-specific information as inputs to the same or similar methodology used to calculate Tier 1 action levels. The Tier 2 SSTLs are then compared to individual sample results from reasonable points of exposure (as opposed to the source areas as is done in Tier 1) on a point-by-point basis. The TPH concentrations will not be used for risk-based decisions under Tier 2 or Tier 3 . Rather, the individual chemicals of concern will be compared to the SSTLs.

- Tier 3 evaluation - Conducted by calculating Tier 3 SSTLs on the basis of more sophisticated risk analyses using methodologies described in Method E 1739-95 that consider site-, pathway-, and receptor-specific parameters.

The comparison of laboratory results to FALs and the evaluation of potential corrective actions will be included in the investigation report. The FALs will be defined (along with the basis for their definition) in the investigation report.

\section{A.7.2.1 Chemical PALs}

Except as noted herein, the chemical PALs are defined as the EPA Region 9 Risk-Based Preliminary Remediation Goals (PRGs) for chemical contaminants in industrial soils (EPA, 2004). Background concentrations for RCRA metals and zinc will be used instead of PRGs when natural background concentrations exceed the PRG, as is often the case with arsenic on the NTS. Background is considered the average concentration plus two standard deviations of the average concentration for sediment samples collected by the Nevada Bureau of Mines and Geology throughout the Nevada Test and Training Range (formerly the Nellis Air Force Range) (NBMG, 1998; Moore, 1999). For detected chemical COPCs without established PRGs, the protocol used by the EPA Region 9 in establishing PRGs (or similar) will be used to establish PALs. If used, this process will be documented in the investigation report. 


\section{A.7.2.2 Total Petroleum Hydrocarbon PALs}

The PAL for TPH is 100 ppm as listed in NAC 445A.2272 (NAC, 2006c).

\section{A.7.2.3 Radionuclide PALs}

The PALs for radiological contaminants (other than tritium) are based on the NCRP Report No. 129 recommended screening limits for construction, commercial, industrial land-use scenarios (NCRP, 1999) scaled to 25 mrem/yr dose constraint (Murphy, 2004) and the generic guidelines for residual concentration of radionuclides in DOE Order 5400.5 (DOE, 1993). These PALs are based on the construction, commercial, and industrial land-use scenario provided in the guidance and are appropriate for the NTS based on future land use scenarios as presented in Section A.3.2. The PAL for tritium is based on the UGTA Project limit of 400,000 pCi/L for discharge of water containing tritium (NNSA/NV, 2002b).

Solid media such as concrete and/or structures may pose a potential radiological exposure risk to site workers if contaminated. The radiological PAL for solid media will be defined as the unrestricted-release criteria defined in the NV/YMP RadCon Manual (NNSA/NSO, 2004).

\section{A.7.3 Decision Rules}

The decision rules applicable to both Decision I and Decision II are:

- If COC contamination is inconsistent with the CSM, or extends beyond the spatial boundaries identified in Section A.6.2, then work will be suspended and the investigation strategy reconsidered, else the decision will be to continue sampling to define the extent.

The decision rules for Decision I are:

- If the population parameter any COPC in the Decision I population of interest (defined in Step 4) exceeds the corresponding FAL, then that contaminant is identified as a COC, and Decision II samples will be collected, else no further investigation is needed for that COPC in that population.

- If a COC exists at any CAS, then a corrective action will be determined, else no further action will be necessary. 
- If a waste is present that, if released, has the potential to cause the future contamination of site environmental media, then a corrective action will be determined, else no further action will be necessary.

The decision rules for Decision II are:

- If the population parameter (the observed concentration of any COC) in the Decision II population of interest (defined in Step 4) exceeds the corresponding FAL in any bounding direction, then additional samples will be collected to complete the Decision II evaluation, else the extent of the COC contamination has been defined.

- If valid analytical results are available for the waste characterization samples defined in Section A.9.0, then the decision will be that sufficient information exists to determine potential remediation waste types and evaluate the feasibility of remediation alternatives, else collect additional waste characterization samples. 


\section{A.8.0 Step 6 - Specify Performance or Acceptance Criteria}

Step 6 of the DQO process defines the decision hypotheses, specifies controls against false rejection and false acceptance decision errors, examines consequences of making incorrect decisions from the test, and places acceptable limits on the likelihood of making decision errors.

\section{A.8.1 Decision Hypotheses}

The baseline condition (i.e., null hypothesis) and alternative condition for Decision I are:

- $\quad$ Baseline condition - A COC is present.

- Alternative condition - A COC is not present.

The baseline condition (i.e., null hypothesis) and alternative condition for Decision II are:

- $\quad$ Baseline condition - The extent of a COC has not been defined.

- Alternative condition - The extent of a COC has been defined.

Decisions and/or criteria have false negative or false positive errors associated with their determination. The impact of these decision errors and the methods that will be used to control these errors are discussed in the following subsections. In general terms, confidence in DQO decisions based on judgmental sampling results will be established qualitatively by:

- Development and concurrence of CSMs (based on process knowledge) by stakeholder participants during the DQO process.

- Validity testing of CSMs based on investigation results.

- Evaluation of the data quality based on DQI parameters.

\section{A.8.2 False Negative Decision Error}

The false negative decision error would mean deciding that a COC is not present when it actually is (Decision I), or deciding that the extent of a COC has been defined when it has not (Decision II). In both cases, the potential consequence is an increased risk to human health and environment. 
In judgmental sampling, the selection of the number and location of samples is based on knowledge of the feature or condition under investigation and on professional judgment (EPA, 2002). Judgmental sampling conclusions about the target population depend upon the validity and accuracy of professional judgment.

The false negative decision error (where consequences are more severe) for judgmental sampling designs is controlled by meeting these criteria:

- For Decision I, having a high degree of confidence that the sample locations selected will identify COCs if present anywhere within the CAS. For Decision II, having a high degree of confidence that the sample locations selected will identify the extent of COCs.

- Having a high degree of confidence that analyses conducted will be sufficient to detect any COCs present in the samples.

- Having a high degree of confidence that the dataset is of sufficient quality and completeness.

To satisfy the first criterion, Decision I samples must be collected in areas most likely to be contaminated by COCs (supplemented by random samples where appropriate). Decision II samples must be collected in areas that represent the lateral and vertical extent of contamination (above FALs). The following characteristics must be considered to control decision errors for the first criterion:

- $\quad$ Source and location of release

- Chemical nature and fate properties

- Physical transport pathways and properties

- Hydrologic drivers

These characteristics were considered during the development of the CSMs and selection of sampling locations. The field-screening methods and biasing factors listed in Section A.5.2.1 will be used to further ensure that appropriate sampling locations are selected to meet these criteria. Radiological survey instruments and field-screening equipment will be calibrated and checked in accordance with the manufacturer's instructions and approved procedures. The investigation report will present an assessment on the DQI of representativeness that samples were collected from locations that best represent the populations of interest as defined in Section A.6.1. 
To satisfy the second criterion, Decision I samples will be analyzed for the chemical and radiological parameters listed in Section 3.2. Decision II samples will be analyzed for those chemical and radiological parameters that identified unbounded COCs. The DQI of sensitivity will be assessed for all analytical results to ensure that all sample analyses had measurement sensitivities (detection limits) that were less than or equal to the corresponding FALs. If this criterion is not achieved, the affected data will be assessed (for usability and potential impacts on meeting site characterization objectives) in the investigation report.

To satisfy the third criterion, the entire dataset, as well as individual sample results, will be assessed against the DQIs of precision, accuracy, comparability, and completeness as defined in the Industrial Sites QAPP (NNSA/NV, 2002a) and in Section 6.2.2 of this document. The DQIs of precision and accuracy will be used to assess overall analytical method performance as well as to assess the need to potentially “flag” (qualify) individual contaminant results when corresponding QC sample results are not within the established control limits for precision and accuracy. Data qualified as estimated for reasons of precision or accuracy may be considered to meet the constituent performance criteria based on an assessment of the data. The DQI for completeness will be assessed to ensure that all data needs identified in the DQO have been met. The DQI of comparability will be assessed to ensure that all analytical methods used are equivalent to standard EPA methods so that results will be comparable to regulatory action levels that have been established using those procedures. Strict adherence to established procedures and QA/QC protocol protects against false negatives. Site-specific DQIs are discussed in more detail in Section 6.2.2.

To provide information for the assessment of the DQIs of precision and accuracy, the following quality control samples will be collected as required by the Industrial Sites QAPP

(NNSA/NV, 2002a):

- Field duplicates (minimum of 1 per matrix per 20 environmental samples)

- Laboratory QC samples (minimum of 1 per matrix per 20 environmental samples or 1 per CAS per matrix, if less than 20 collected) 


\section{A.8.3 False Positive Decision Error}

The false positive decision error would mean deciding that a COC is present when it is not, or a COC is unbounded when it is not, resulting in increased costs for unnecessary sampling and analysis.

False positive results are typically attributed to laboratory and/or sampling/handling errors that could cause cross contamination. To control against cross contamination, decontamination of sampling equipment will be conducted according to established and approved procedures and only clean sample containers will be used. To determine whether a false positive analytical result may have occurred, the following quality control samples will be collected as required by the Industrial Sites QAPP (NNSA/NV, 2002a):

- Trip blanks (1 per sample cooler containing VOC environmental samples)

- Equipment blanks (1 per sampling event for each type of decontamination procedure)

- $\quad$ Source blanks (1 per source lot per sampling event)

- Field blanks (minimum of 1 per CAS, additional if field conditions change) 


\section{A.9.0 Step 7 - Develop the Plan for Obtaining Data}

Step 7 of the DQO process selects and documents a design that will yield data that will best achieve performance or acceptance criteria. Judgmental sampling schemes will be implemented to select sample locations and evaluate analytical results for CAU 234. Sections A.9.1 through A.9.2 contain general information about collecting Decision I and Decision II samples under judgmental sampling designs, while the subsequent sections provide CAS-specific sampling activities, including proposed sample locations.

A judgmental sampling design will be implemented for all CASs requiring sampling. Because individual sample results, rather than an average concentration, will be used to compare to FALs at the CASs undergoing judgmental sampling, statistical methods to generate site characteristics will not be used. Adequate representativeness of the entire target population may not be a requirement to developing a sampling design. If good prior information is available on the target site of interest, then the sampling may be designed to collect samples only from areas known to have the highest concentration levels on the target site. If the observed concentrations from these samples are below the action level, then a decision can be made that the site contains safe levels of the contaminant without the samples being truly representative of the entire area (EPA, 2006).

\section{A.9.1 Decision I Sampling}

All sample locations will be selected to satisfy the DQI of representativeness in that samples collected from selected locations will best represent the populations of interest as defined in Section A.6.1. To meet this criterion for judgmentally sampled sites, a biased sampling strategy will be used for Decision I samples to target areas with the highest potential for contamination, if it is present anywhere in the CAS. Sample locations will be determined based on process knowledge, previously acquired data, or the field-screening and biasing factors listed in Section A.5.2.1. If biasing factors are present in soils below locations where Decision I samples were removed, additional Decision I soil samples will be collected at depth intervals selected by the Site Supervisor based on biasing factors to a depth where the biasing factors are no longer present. The Site Supervisor has the discretion to modify the judgmental sample locations, but only if the modified locations meet the decision needs and criteria stipulated in this DQO. 


\section{A.9.2 Decision II Sampling}

To meet the DQI of representativeness for Decision II samples (that Decision II sample locations represent the population of interest as defined in Section A.6.1), judgmental sampling locations at each CAS will be selected based on the outer boundary sample locations where COCs were detected, the CSM, and other field-screening and biasing factors listed in Section A.5.2. In general, sample locations will be arranged in a triangular pattern around the Decision I location or area at distances based on site conditions, process knowledge, and biasing factors. If COCs extend beyond the initial step-outs, Decision II samples will be collected from incremental step-outs. Initial step-outs will be at least as deep as the vertical extent of contamination defined at the Decision I location, and the depth of the incremental step-outs will be based on the deepest contamination observed at all locations. A clean sample (i.e., COCs less than FALs) collected from each step-out direction (lateral or vertical) will define extent of contamination in that direction. The number, location, and spacing of step-outs may be modified by the Site Supervisor, as warranted by site conditions.

\section{A.9.3 Corrective Action Site 02-09-48, Area 2 Mud Plant \#1}

During Decision I sampling at CAS 02-09-48, the following features will be sampled:

- Soil samples will be collected at the location of the barrel that is situated near the southern end of the mud sump. The actual location will be selected based on biasing factors (i.e., staining) and site conditions as documented during the initial visual inspection. A minimum of one surface soil sample will be collected beneath the barrel. A second sample will be collected approximately 1 to $1.5 \mathrm{ft}$ bgs beneath the location of the surface sample. Additional samples may be collected based on biasing factors identified at the time of sampling.

- If residual material is present in adequate volume within the barrel, a sample will be collected for analysis to support waste characterization.

Proposed Decision I sampling locations are shown in Figure A.9-1. 


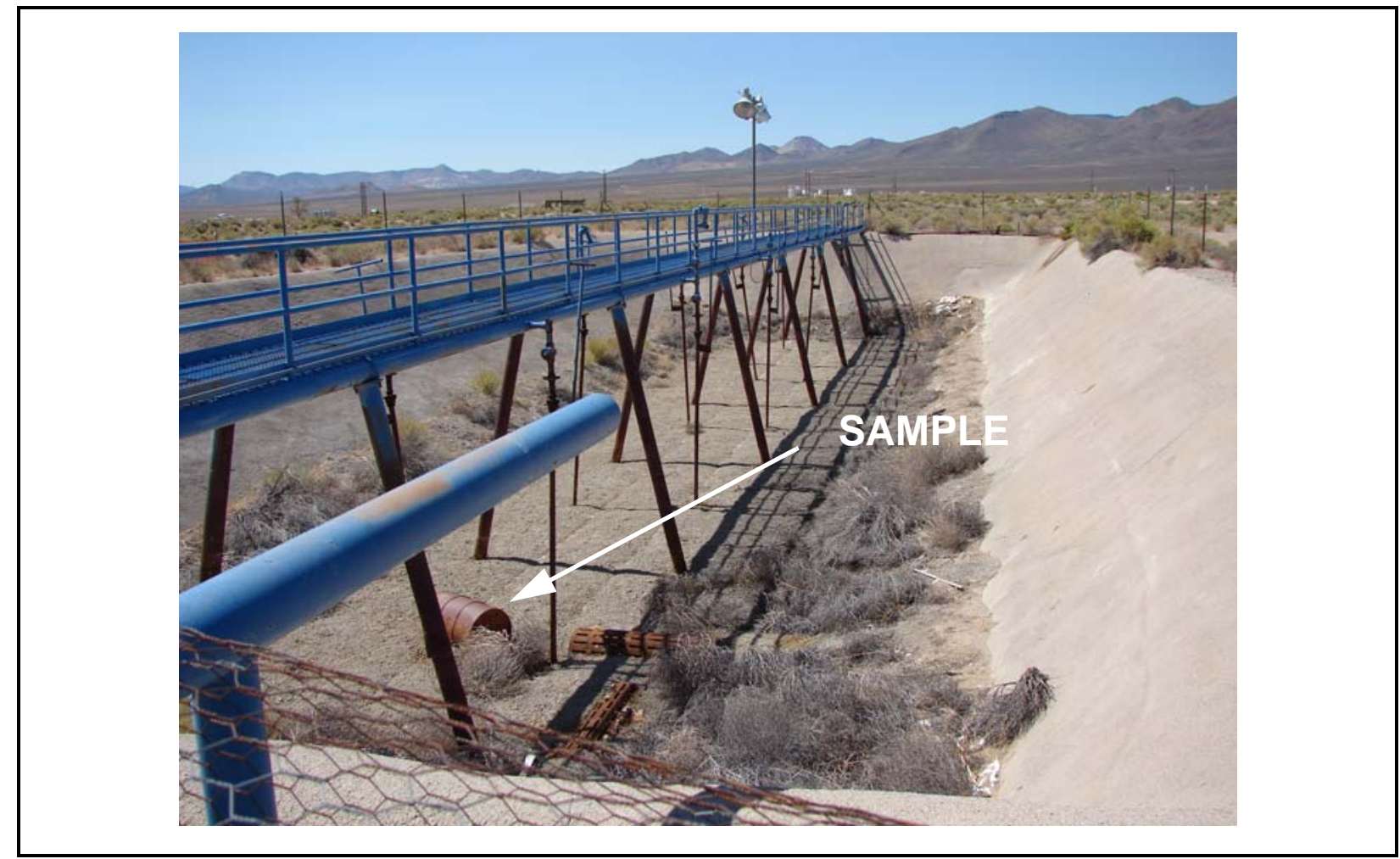

Figure A.9-1

Proposed Sample Location at CAS 02-09-48

\section{A.9.4 Corrective Action Site 03-09-02, Mud Dump Trenches}

During Decision I sampling at CAS 03-09-02, the following features will be sampled:

- The mud pit in the northern footprint will be sampled based upon the results obtained from a radiological screening of the pit that will be conducted before sampling. One surface and one sub-surface sample will be collected at the location of highest radiation, or at the point of lowest elevation if no specific location is identified by radiological screening.

- Once the tumbleweeds that fill the suction pit in the northern footprint are removed, it will be sampled at a location identified as the highest reading from a radiological survey that will be conducted before sampling. If no area of elevated reading is identified during the radiological survey, the lowest point in elevation within the suction pit will be sampled. A surface and sub-surface sample will be collected at the location selected. In addition, once the tumbleweeds are cleared from the suction pit, surface and sub-surface samples will be collected from beneath the blue pipe discarded in the pit. The selection of an appropriate sample location will be based on biasing factors. If a potential for release also involves a container with a liquid or solid that may be considered as source material, a sample of the material will be collected for waste characterization. 
- In the southern footprint, each of the two parallel mud pits will be sampled at the site of lowest elevation. A radiological screen of the mud pits will be conducted and sampling will occur at an additional location, if the results are significantly above background. Additional samples may be collected based on biasing factors identified during the sampling event. Both a surface and a sub-surface sample will be collected at each location identified for sampling.

Proposed Decision I sample locations are shown in Figures A.9-2, A.9-3, and A.9-4.

\section{A.9.5 Corrective Action Site 12-09-01, Mud Pit}

During Decision I sampling at CAS 12-09-01, the following features will be sampled:

- A surface sample will be collected at a location adjacent to the metal pipe. The specific location will be identified through the recognition of a biasing factor(s), or will be identified as the lowest point of elevation (i.e., depressed area of potential contaminant accumulation) associated with the pipe. If additional biasing factors are identified, additional samples will be collected and the rationale for collection documented. Both surface and sub-surface samples will be collected at each sampling location selected. If the pipe contains material of sufficient volume, a sample of the material will be collected to support waste characterization.

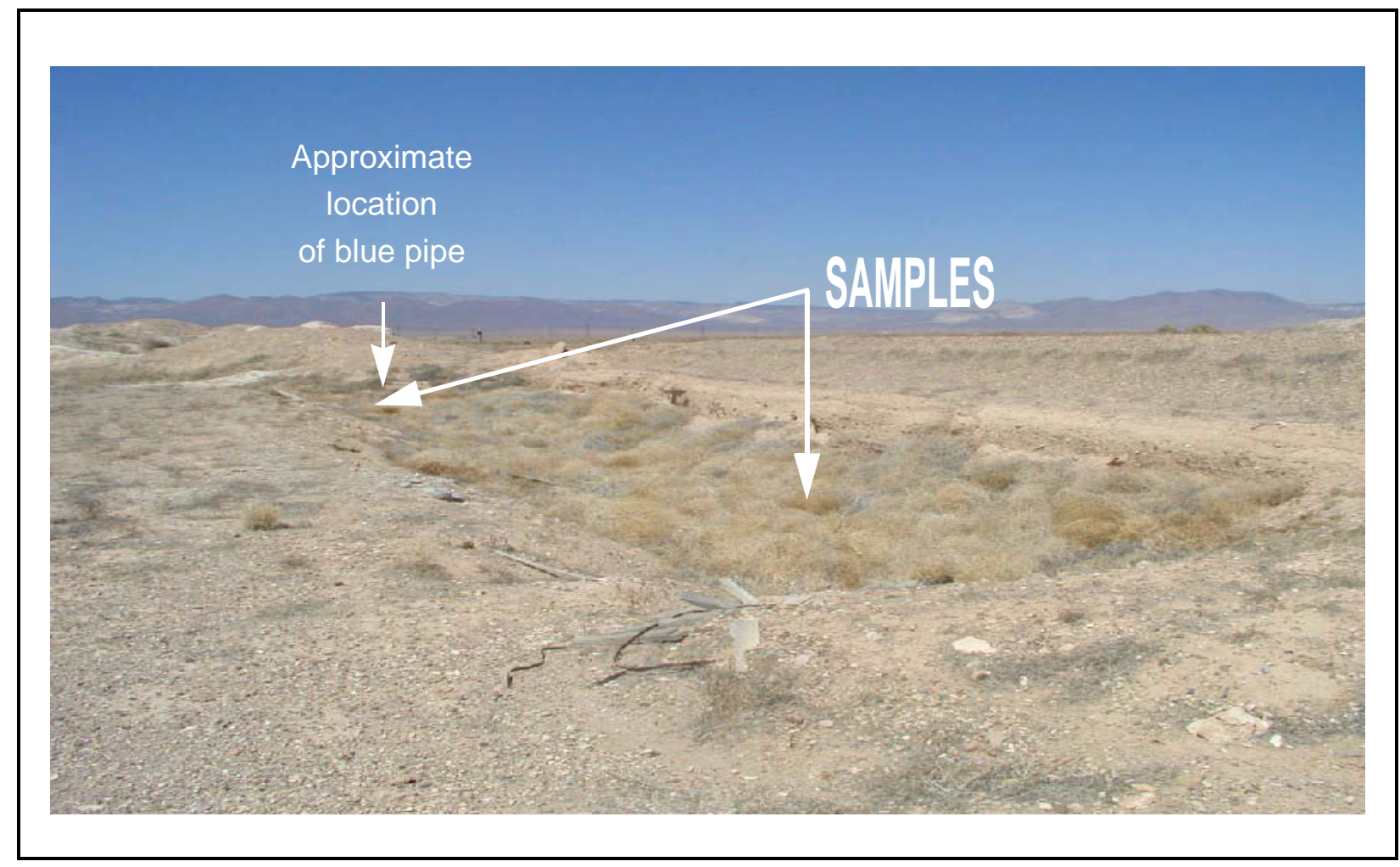

Figure A.9-2

Proposed Suction Pit Sample Location(s) at CAS 03-09-02 


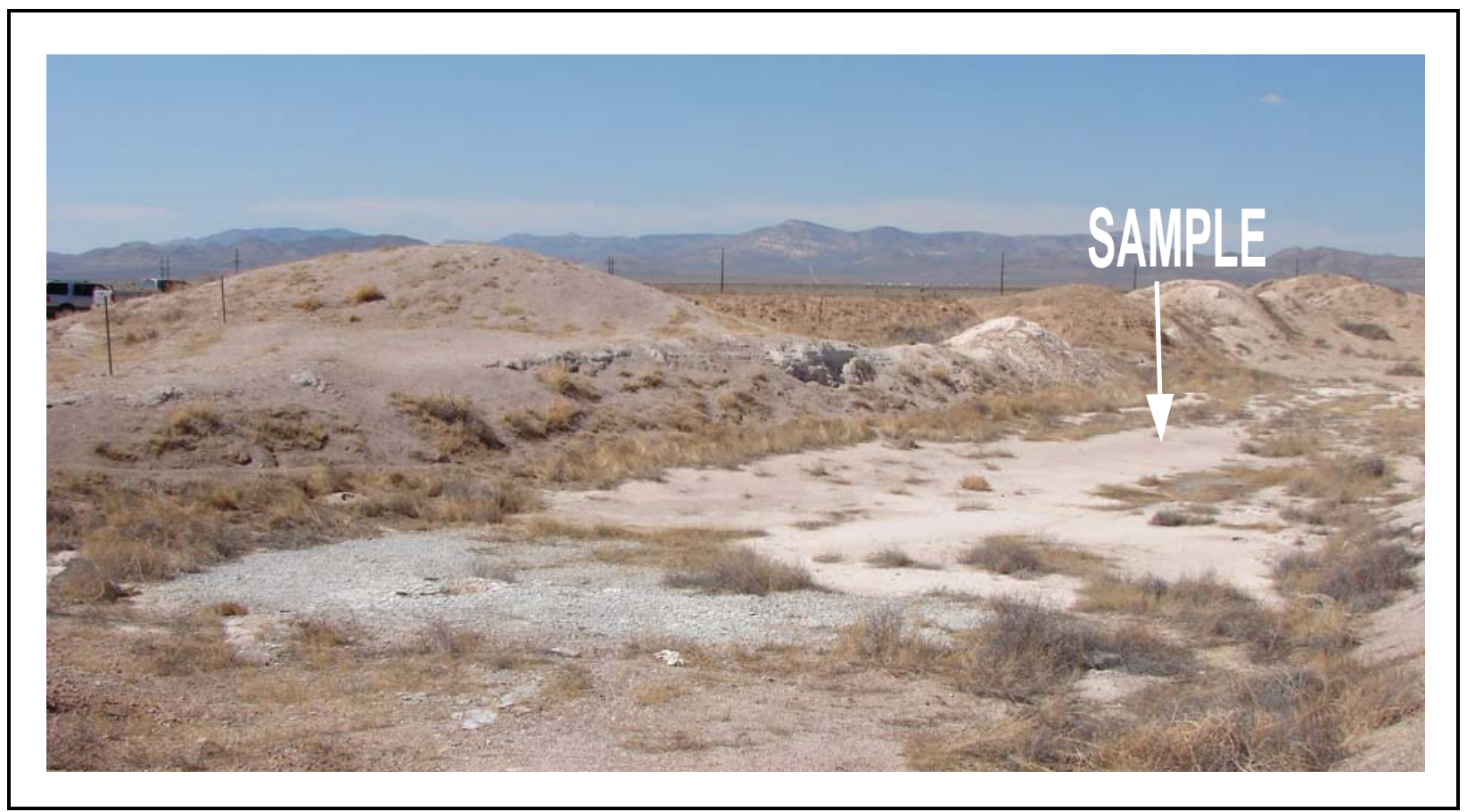

Figure A.9-3

Proposed Mud Pit Sample Location at CAS 03-09-02

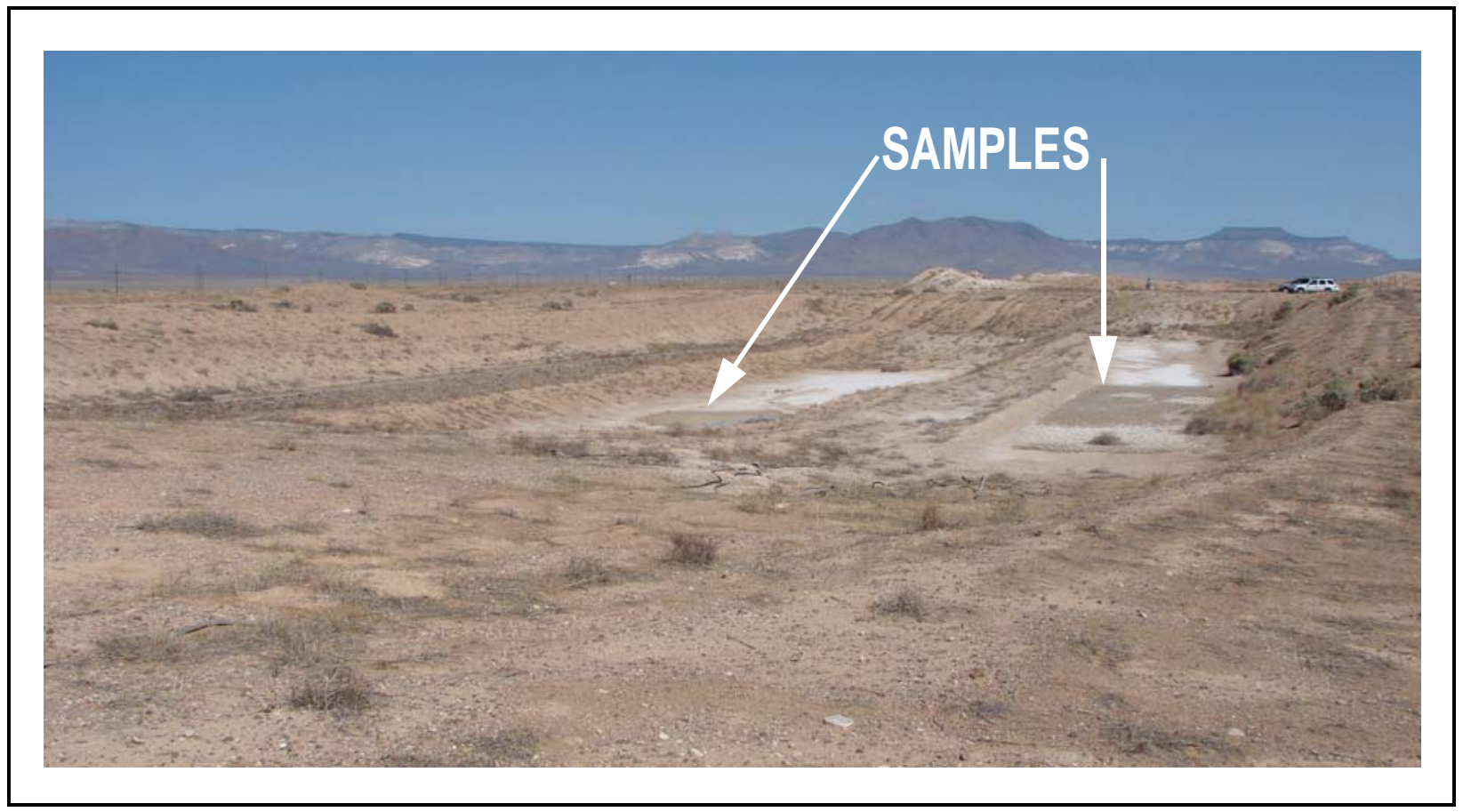

Figure A.9-4

Proposed Borrow Pit Sample Locations at CAS 03-09-02 
- A surface sample will be collected at a location adjacent to the large piece of cylindrical metal debris. The sample location will be identified by the presence of biasing factors, or in the absence of biasing factors, a sample will be collected from the lowest point of elevation (i.e., depressed area of potential contaminant accumulation) associated with the debris. If additional biasing factors are identified, additional samples will be collected and the rationale for selection documented. Both surface and sub-surface samples will be collected at each sampling location selected.

Proposed Decision I sampling locations are shown in Figure A.9-5.

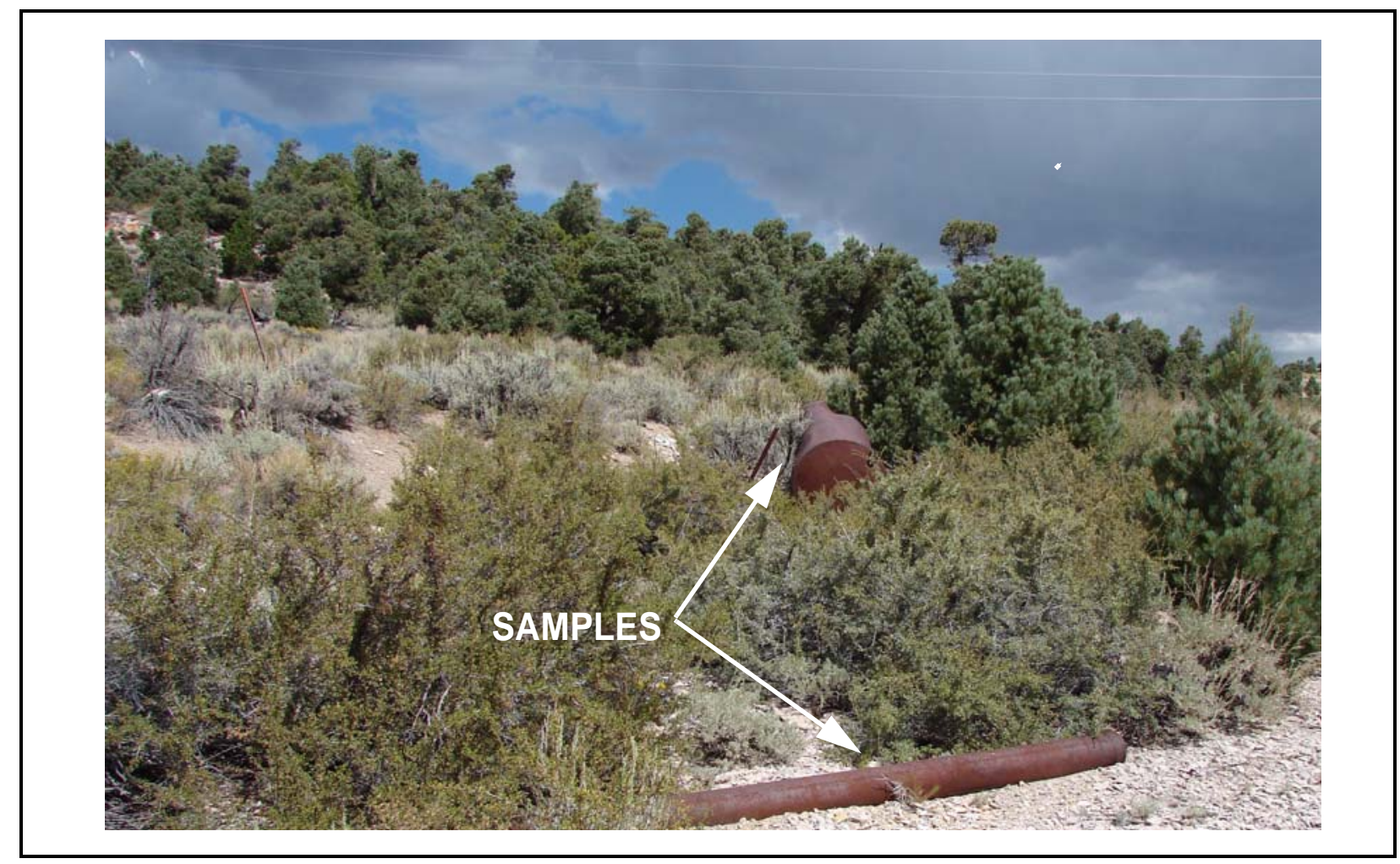

Figure A.9-5

Proposed Sample Locations at CAS 12-09-01

\section{A.9.6 Corrective Action Site 12-09-08, Mud Pit}

During Decision I sampling at CAS 12-09-08, the following features will be sampled:

- A sample will be collected from the area adjacent to the metal pipe protruding from the southeast corner berm of the mud pit. The specific location will be identified through the recognition of a biasing factor(s), or as the lowest point of elevation (i.e., depressed area of potential contaminant accumulation) associated with the pipe. A surface and sub-surface sample will be collected at the selected sampling location. If additional samples are collected 
based on the recognition of biasing factors, surface and sub-surface samples will be collected, and the rationale for selection of the sampling location will be documented. If the pipe contains material (other than the berm material in which it sits) that exhibits a potential to release, a sample of the material will be collected to support waste management

- A sample will be collected from the pile of crushed drums located on the inside slope of the eastern berm of the mud pit. The sample location will be identified by the presence of biasing factors, or at a location that is determined to be the most likely to accumulate contaminants (e.g., a depressed area adjacent to the drums). A surface and sub-surface sample will be collected from the selected location. If other sample locations are identified through the recognition of biasing factors, surface and sub-surface samples will be collected, and the rationale for the selection of the sample location documented.

Proposed Decision I sampling locations are shown in Figure A.9-6.

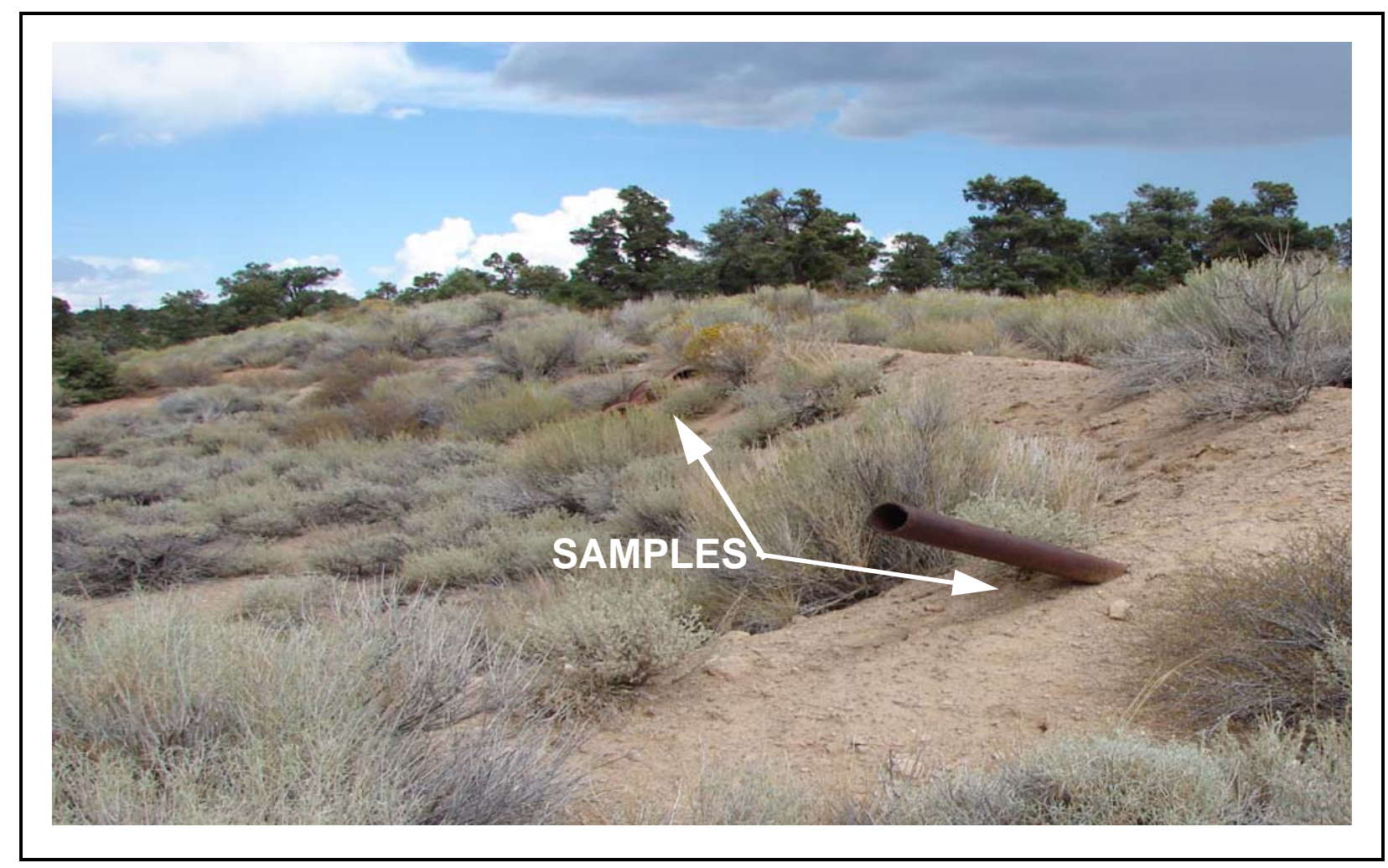

Figure A.9-6

Proposed Sample Locations at CAS 12-09-08 


\section{A.9.7 Corrective Action Site 12-30-14, Cellar}

During Decision I sampling at CAS 12-30-14, the following features will be sampled:

- Samples of the liquid and sediment from the cellar floor will each be collected for analysis. If there is insufficient sediment for sample collection, then only the liquid within the cellar will be sampled and analyzed. Because of the depressed location of the cellar relative to the surrounding terrain, the liquid in the cellar is believed to be rainwater/snowmelt that has channeled into the cellar. Channels are visible running downslope toward the open cellar through which rain water and snowmelt are transported. During heavy rains, the runoff would likely contain sediment that is then deposited on the cellar floor.

Proposed Decision I sampling locations are shown in Figure A.9-7.

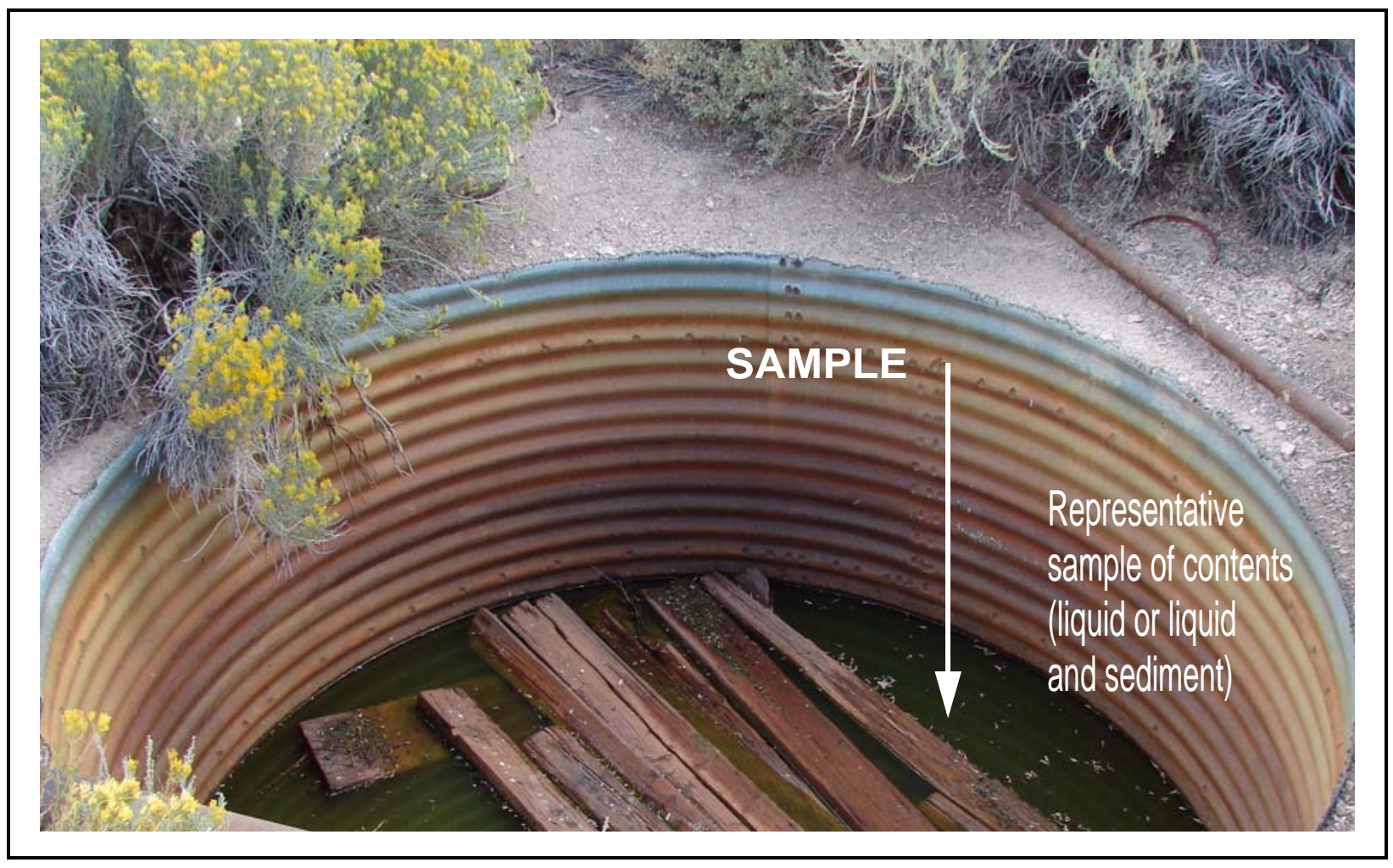

Figure A.9-7

Proposed Sample Location at CAS 12-30-14 


\section{A.10.0 References}

ARL/SORD, see Air Resources Laboratory/Special Operations and Research Division.

ASTM, see American Society for Testing and Materials.

Air Resources Laboratory/Special Operations and Research Division. 2007. NTS Climatological Rain Gauge Data. As accessed at http://www.sord.nv.doe.gov/home_climate_rain.htm on 13 April.

American Society for Testing and Materials. 1995. Standard Guide for Risk-Based Corrective Action Applied at Petroleum Release Sites, ASTM E 1739-95 (Reapproved 2002). Philadelphia, PA.

DOE, see U.S. Department of Energy.

DOE/NV, see U.S. Department of Energy, Nevada Operations Office.

EPA, see U.S. Environmental Protection Agency.

Moore, J., Science Applications International Corporation. 1999. Memorandum to M. Todd (SAIC) entitled, "Background Concentrations for N33.

Murphy, T., Bureau of Federal Facilities. 2004. Letter to R. Bangerter (NNSA/NSO) entitled, "Review of Industrial Sites Project Document Guidance for Calculating Industrial Sites Project Remediation Goals for Radionuclides in Soil Using the Residual Radiation (RESRAD) Computer Code.” 19 November. Las Vegas, NV.

NAC, see Nevada Administrative Code.

NBMG, see Nevada Bureau of Mines and Geology.

NCRP, see National Council on Radiation Protection and Measurements.

NNSA/NSO, see U.S. Department of Energy, National Nuclear Security Administration Nevada Site Office.

NNSA/NV, see U.S. Department of Energy, National Nuclear Security Administration Nevada Operations Office.

National Council on Radiation Protection and Measurements. 1999. Recommended Screening Limits for Contaminated Surface Soil and Review of Factors Relevant to Site-Specific Studies, NCRP Report No. 129. Bethesda, MD. 
Nevada Administrative Code. 2006a. NAC 445A.227, “Contamination of Soil: Order by Director for Corrective Action; Factors To Be Considered in Determining Whether Corrective Action Required.” Carson City, NV. As accessed at http://www.leg.state.nv.us/nac on 10 August.

Nevada Administrative Code. 2006b. NAC 445A.22705, “Contamination of Soil: Evaluation of Site by Owner or Operator; Review of Evaluation by Division.” Carson City, NV. As accessed at http://www.leg.state.nv.us/nac on 10 August.

Nevada Administrative Code. 2006c. NAC 445A.2272, "Contamination of Soil: Establishment of Action Levels.” Carson City, NV. As accessed at http://www.leg.state.nv.us/nac on 10 August.

Nevada Bureau of Mines and Geology. 1998. Mineral and Energy Resource Assessment of the Nellis Air Force Range, Open-File Report 98-1. Reno, NV.

Shott, G.J., V. Yucel, M.J. Sully, L.E. Barker, S.E. Rawlinson, and B.A. Moore. 1997. Performance Assessment/Composite Analysis for the Area 3 Radioactive Waste Management Site at the Nevada Test Site, Nye County, Nevada, Rev. 2.0. Las Vegas, NV.

SNJV GIS Systems, see Stoller-Navarro Joint Venture Geographic Information Systems.

Stoller-Navarro Joint Venture Geographic Information Systems. 2007. ESRI Arc GIS Software.

U.S. Department of Energy. 1993. Radiation Protection of the Public and the Environment, DOE Order 5400.5, Change 2. Washington, DC: U.S. Government Printing Office.

U.S. Department of Energy, National Nuclear Security Administration Nevada Operations Office. 2002a. Industrial Sites Quality Assurance Project Plan, Nevada Test Site, Nevada, Rev. 3, DOE/NV--372. Las Vegas, NV.

U.S. Department of Energy, National Nuclear Security Administration Nevada Operations Office. 2002b. Underground Test Area Project Waste Management Plan, Rev. 2, DOE/NV--343. Las Vegas, NV.

U.S. Department of Energy, National Nuclear Security Administration Nevada Site Office. 2004. NV/YMP Radiological Control Manual, Rev. 5, DOE/NV/11718-079. Prepared by Bechtel Nevada. Las Vegas, NV.

U.S. Department of Energy, National Nuclear Security Administration Nevada Site Office. 2006a. Closure Report for Corrective Action Units 530, 531, 532, 533, 534, 535: NTS Mud Pits, Nevada Test Site, Nevada, Rev. 0, DOE/NV--1131. Las Vegas, NV.

U.S. Department of Energy, National Nuclear Security Administration Nevada Site Office. 2006b. Industrial Sites Project Establishment of Final Action Levels, Rev. 0, DOE/NV--1107. Las Vegas, NV. 
U.S. Department of Energy, Nevada Operations Office. 1992. Remedial Investigation and Feasibility Study for the Plutonium Contaminated Soils at Nevada Test Site, Nellis Air Force Range and Tonopah Test Range, April. Las Vegas, NV.

U.S. Environmental Protection Agency. 2002. Guidance for Quality Assurance Project Plans, EPA QA/G5. Washington, DC.

U.S. Environmental Protection Agency. 2004. Region 9 Preliminary Remediation Goals (PRGs). As accessed at http://www.epa.gov/region09/waste/sfund/prg/index.htm on 10 August. Prepared by S.J. Smucker. San Francisco, CA.

U.S. Environmental Protection Agency. 2006. EPA Guidance on Systematic Planning Using the Data Quality Objectives Process, EPA QA/G-4. Washington, DC. 


\section{Appendix B}

\section{Project Organization}




\section{B.1.0 Project Organization}

The NNSA/NSO Acting Federal Sub-Project Manager is Sabine Curtis. She can be contacted at (702) 295-0542. The NNSA/NSO Task Manager is Peter Sanders. He can be contacted at (702) 295-1037.

The identification of the project Health and Safety Officer and the Quality Assurance Officer can be found in the appropriate plan. However, personnel are subject to change and it is suggested that the DOE Federal Sub-Project Director be contacted for further information. The Task Manager will be identified in the FFACO Monthly Activity Report before the start of field activities. 


\title{
Appendix C
}

\section{Nevada Division of Environmental Protection Comment Responses}

\author{
(1 Page)
}




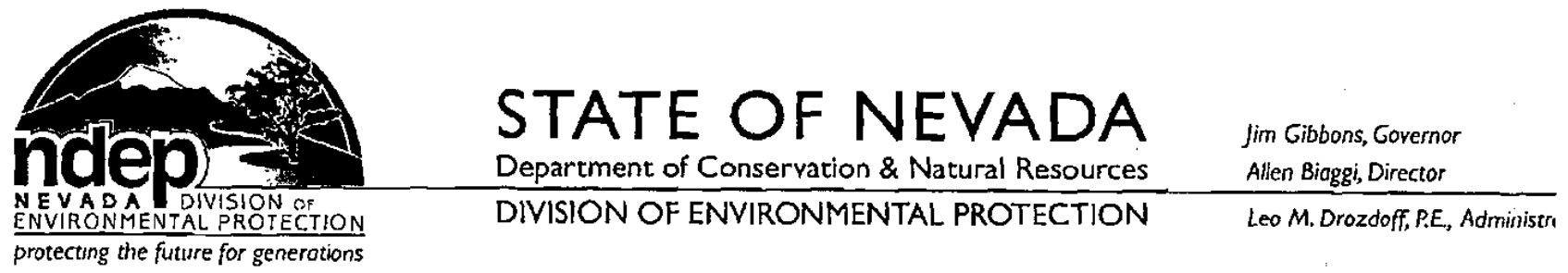

July 17,2007

Mr. John 8. Jones

Acting Environmental Restoration Federal Project Director

Environmental Restoration Project

National Nuclear Security Administration

Nevada Site Office

P. O. Box 98518

Las Vegas, NV 89193-8518

RE: Review of the Draft Corrective Action Investigation Plan (CAIP) Corrective Action Unit (CAU) 234: Mud Pits, Cellars, and Mud Spills Federal Facility Agreement and Consent Order

Dear Mr. Jones,

The Nevada Division of Environmental Protection, Bureau of Federal Facilities (NDEP) staff has received and reviewed the draft Corrective Action Investigation Plan (CAIP) for Corrective Action Unit (CAU) 234: Mud Pits, Cellars, and Mud Spills. There are no comments for this draft report.

If you have any questions regarding this matter, please contact me at (702) 486-2850, extension 229.

Sincerely,

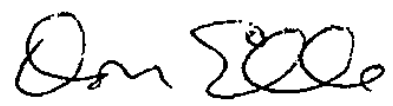

Don Elle, Ph.D.

Supervisor

Bureau of Federal Facilities

cc: Ken Hoar, AD/AMSP, NNSAINSO, Las Vegas, NV

E.F. DiSanza, WMP, NNSANNSO

FFACO Group, PSG, NNSANSO, Las Vegas, NV

Tiffany Lantow, DTRA/CXT1, M/S 645, Mercury, NV

J. A. Ciucci, NSTec, Las Vegas, NV

A. L. Primrose, NSTec, Las Vegas, NV

J. L. Smith, NSTec, Las Vegas, NV

Kevin Cabble, ERP, NNSA/NSO, Las Vegas, NV

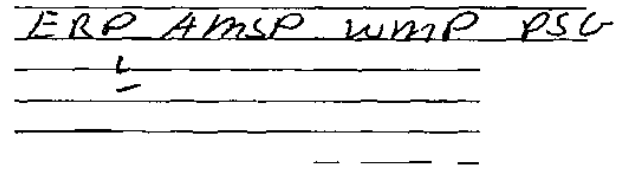




\title{
Library Distribution List
}

\author{
$\underline{\text { Copies }}$ \\ U.S. Department of Energy \\ 1 (Uncontrolled, electronic copy) \\ National Nuclear Security Administration \\ Nevada Site Office \\ Technical Library \\ P.O. Box 98518, M/S 505 \\ Las Vegas, NV 89193-8518 \\ U.S. Department of Energy \\ Office of Scientific and Technical Information \\ 1 (Uncontrolled, electronic copy) \\ P.O. Box 62 \\ Oak Ridge, TN 37831-0062 \\ Southern Nevada Public Reading Facility \\ 2 (Uncontrolled, electronic copies) \\ c/o Nuclear Testing Archive \\ P.O. Box 98521, M/S 400 \\ Las Vegas, NV 89193-8521 \\ Manager, Northern Nevada FFACO \\ 1 (Uncontrolled, electronic copy) \\ Public Reading Facility \\ c/o Nevada State Library \& Archives \\ 100 N Stewart Street \\ Carson City, NV 89701-4285
}

